Andrews University

Digital Commons @ Andrews University

1994

\title{
Seventh-day Adventist Worship: A Course for Pastoral Students at Montemorelos University, Mexico
}

Hector Enrique Ramal

Andrews University

Follow this and additional works at: https://digitalcommons.andrews.edu/dmin

Part of the Practical Theology Commons

\section{Recommended Citation}

Ramal, Hector Enrique, "Seventh-day Adventist Worship: A Course for Pastoral Students at Montemorelos University, Mexico" (1994). Professional Dissertations DMin. 624.

https://dx.doi.org/10.32597/dmin/624

https://digitalcommons.andrews.edu/dmin/624

This Project Report is brought to you for free and open access by the Graduate Research at Digital Commons @ Andrews University. It has been accepted for inclusion in Professional Dissertations DMin by an authorized administrator of Digital Commons @ Andrews University. For more information, please contact repository@andrews.edu. 


\begin{abstract}
SEVENTH-DAY ADVENTIST WORSHIP: A COURSE FOR PASTORAL STUDENTS AT MONTEMORELOS UNIVERSITY, MEXICO
\end{abstract}

by

Héctor Enrique Ramal

Adviser: C. Raymond Holmes 


\section{ABSTRACT OF GRADUATE STUDENT RESEARCH}

\section{Project Report}

Andrews University

Seventh-day Adventist Theological Seminary

Title: SEVENTH-DAY ADVENTIST WORSHIP: A COURSE FOR PASTORAL STUDENTS AT MONTEMORELOS UNIVERSITY, MEXICO

Name of researcher: Héctor Enrique Ramal

Name and degree of faculty adviser: C. Raymond Holmes, D.Min.

Date completed: July 1994

The purpose of this project was to develop an undergraduate course in Seventh-day Adventist worship.

Chapter 1 states the purpose, justification, and expectations of the project. Chapter 2 states the origins and development of worship as these are revealed in the Old and New Testaments.

Chapter 3 considers worship from Ellen G. White's perspective. The concerns, issues, and principles of true worship are found in her writings.

Chapter 4 deals with contemporary issues in worship. The first part of this chapter has to do with the literature review and centers in the Pentecostal 
Movement and its influence on the Christian Church. The second part considers the phenomenon of "celebration churches" in Adventism and how, in recent years, the Seventh-day Adventist Church in North America has been challenged to rethink its historical patters of worship.

Chapter 5 contains the pedagogical methodology, the course objectives, requirements, and basic course outline. Chapter 6 consists of six classroom presentations (three theoretical and three practical). Chapter 7 consists of conclusions and recommendations reached in this study and in the teaching of the course. 
Andrews University

Seventh-day Adventist Theological Seminary

SEVENTH-DAY ADVENTIST WORSHIP: A COURSE FOR

PASTORAL STUDENTS AT MONTEMORELOS

UNIVERSITY, MEXICO

\author{
A Project Report \\ Presented in Partial Fulfillment \\ of the Requirements for the Degree \\ Doctor of Ministry
}

by

Héctor Enrique Ramal

August 1994 



\title{
SEVENTH-DAY ADVENTIST WORSHIP: A COURSE FOR PASTORAL STUDENTS AT MONTEMORELOS UNIVERSITY, MEXICO
}

\author{
A project report \\ presented in partial fulfillment \\ of the requirements for the degree \\ Doctor of Ministry
}

by

Héctor Enrique Ramal

APPROVAL BY THE COMMITTEE:

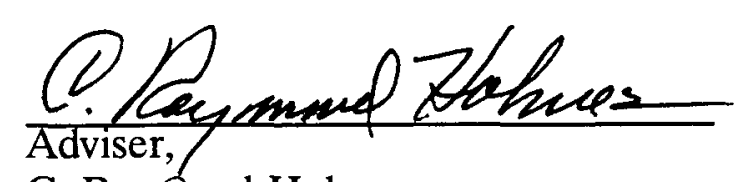

C. Raymond Holmes

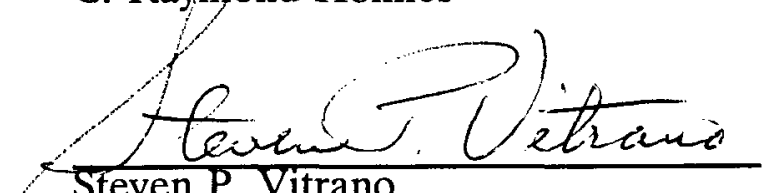

Steven P. Vitrano

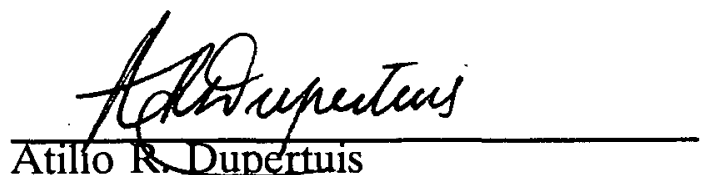

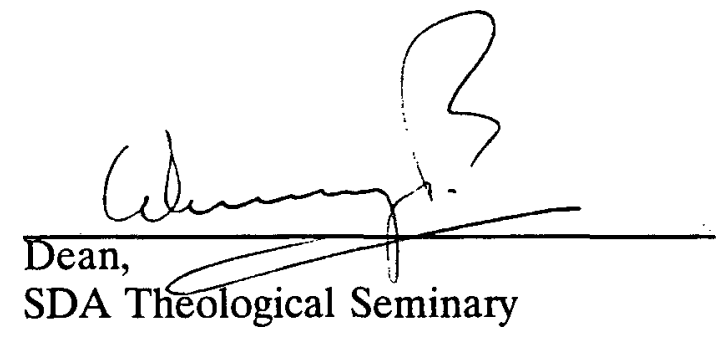

$\frac{J u l y}{\text { Date approved }}$ 


\section{DEDICATION}

I would like to dedicate this project report to my wife, Edelweiss; my best friend and closest companion; my marvelous, patient, sensitive, loving and genuine wife, with me and our children, Joy and Anthony. 


\section{TABLE OF CONTENTS}

ACKNOWLEDGMENTS $\ldots \ldots \ldots \ldots \ldots \ldots \ldots \ldots \ldots$ vii

Chapter

I. INTRODUCTION $\ldots \ldots \ldots \ldots \ldots \ldots \ldots \ldots \ldots \ldots \ldots$

Purpose of the Project ................. 1

Justification of the Project $\ldots \ldots \ldots \ldots \ldots \ldots \ldots \ldots \ldots$

Expectations of the Project $\ldots \ldots \ldots \ldots \ldots \ldots \ldots \ldots 2$

II. BIBLE AND WORSHIP $\ldots \ldots \ldots \ldots \ldots \ldots \ldots \ldots \ldots$

Worship in Old Testament Times . . . . . . . . 4

Creation .................... 4

The Sabbath ................... 6

The Altar and the Lamb ............... 8

"Call on the Name of the Lord" . . . . . . . . . . . 10

Noah ........................... 11

Abraham, Isaac, and Jacob . . . . . . . . . . 13

Worship from the Mosaic Age to the Exile . . . . . . . 15

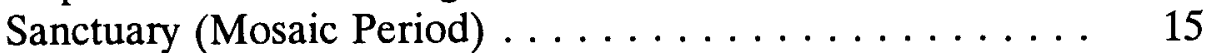

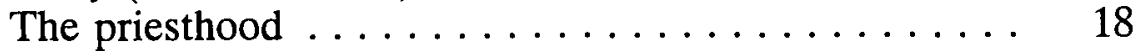

Services .................... 21

Jerusalem Temple (Monarchical Period) . . . . . . . . . 24

The Synagogue (Exilic Period) . . . . . . . . . . . . . 29

Worship in New Testament Times . . . . . . . . . . 32

The Roman Root ................. 33

The Birth of Christ ................. 34

Worship in the Synagogue $\ldots \ldots \ldots \ldots \ldots \ldots \ldots$

Worship in the Temple ................. 38

Worship in the Apostolic Age $\ldots \ldots \ldots \ldots \ldots \ldots \ldots .40$

III. ELLEN G. WHITE AND WORSHIP $\ldots \ldots \ldots \ldots \ldots \ldots \ldots$

Fundamentals of Worship $\ldots \ldots \ldots \ldots \ldots \ldots \ldots \ldots$

Concerns and Issues $\ldots \ldots \ldots \ldots \ldots \ldots \ldots \ldots \ldots \ldots$ 
Principles of Worship in Ellen G. White's Writings . . . . . 52

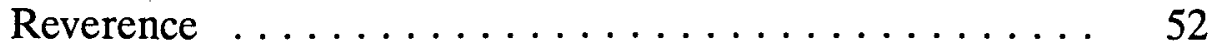

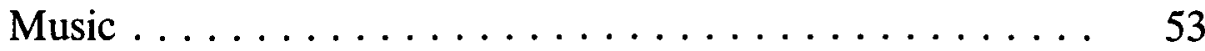

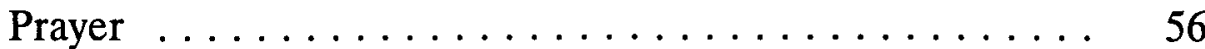

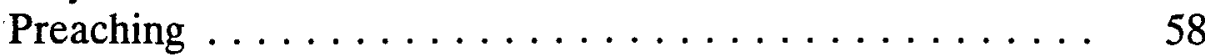

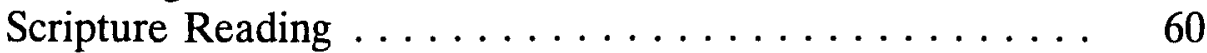

Testimonies ..................... 61

IV. CONTEMPORARY ISSUES IN WORSHIP $\ldots \ldots \ldots \ldots \ldots 63$

History of Pentecostalism in North America . . . . . . . . . 64

The Rise of Pentecostalism . . . . . . . . . . . 64

The Birth of Modern Pentecostalism $\ldots \ldots \ldots \ldots \ldots \ldots \ldots$

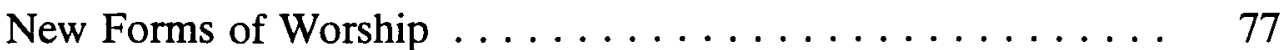

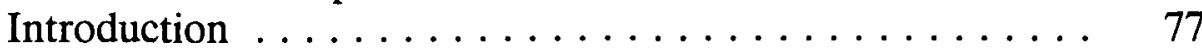

The Three Waves of Wagner . . . . . . . . . . . 78

The Third Wave and Adventist Renewal ......... 83

Early Seventh-day Adventist history . . . . . . . . 83

Beginning of Celebration Churches in Adventism . . . . . . 94

Reaction toward the "Celebration Churches" in Adventism . 98

Critics of the "Celebration Movement" . . . . . . . . . . 100

Supporters of "Celebration Churches" . . . . . . . . . . . 101

Conclusion ... . . . . . . . . . . . . . . . . . . 104

V. DEVELOPMENT OF A BASIC OUTLINE . . . . . . . . 107

Goals $\quad \ldots \ldots \ldots \ldots \ldots \ldots \ldots \ldots \ldots \ldots \ldots \ldots \ldots$

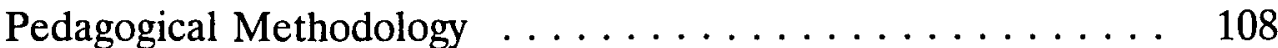

Basic Outline of the Course . . . . . . . . . . . . . . . . . 109

Course Description . . . . . . . . . . . . . . . . 109

Course Objectives . . . . . . . . . . . . . . . . . . . . . 109

Course Requirements . . . . . . . . . . . . . . . 110

Reading ..................... 110

Class activity . . . . . . . . . . . . . . 110

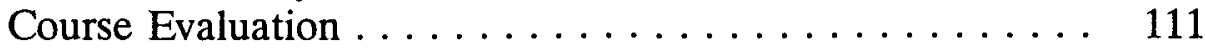

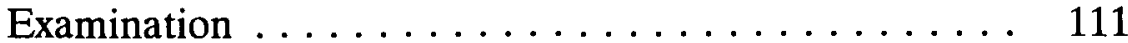

Grading ..................... 111

Course Content . . . . . . . . . . . . . . . 112 
VI. EVALUATION OF THE COURSE $\ldots \ldots \ldots \ldots \ldots \ldots \ldots 116$

Worship Survey and Its Results (Pretest and Posttest) . . . . . 116 Students' Understanding of Seventh-day Adventist

Worship . . . . . . . . . . . . . . . 117

VII. CONCLUSIONS AND RECOMMENDATIONS $\ldots \ldots \ldots \ldots 131$

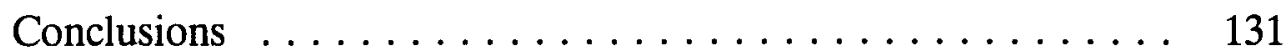

Recommendations .................... 134

Appendix

A. WORSHIP CLASS SURVEY $\ldots \ldots \ldots \ldots \ldots \ldots \ldots \ldots \ldots$

B. SIX CLASSROOM PRESENTATIONS ............ 140

BIBLIOGRAPHY $\ldots \ldots \ldots \ldots \ldots \ldots \ldots \ldots \ldots \ldots \ldots \ldots \ldots \ldots \ldots \ldots \ldots$

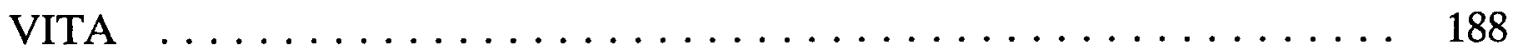




\section{ACKNOWLEDGEMENTS}

The completion of this project has been made possible only by the sustaining power of the Almighty. To Him goes my deepest gratitude and all the glory.

To my wife, Edelweiss; my daughter, Joy; and my son, Anthony, I am particularly indebted. Edelweiss's sacrifice and hard work, her love, and patient endurance enabled me to follow through with my dream of equipping myself to better serve the Lord.

Special recognition is given to the members of my committee, Dr. C. Raymond Holmes, Dr. Atilio R. Dupertuis, and Dr. Steven Vitrano, for their valuable time and constructive criticism.

My sincere thanks go to Mrs. Annick Brennen who helped me with the finished presentation of my project.

Thanks must be given to Mrs. Bonnie Proctor also. Her editorial expertise, her patience, and availability are of much value.

I would like to thank the Inter-American Division and Montemorelos University for allowing me the time to finish the doctoral program.

Lastly, though not least, I would like to thank all my family and friends for supporting me through prayers while I was writing my project report. 


\section{CHAPTER I}

\section{INTRODUCTION}

Man is innately a worshipper, states Dr. Jaime Cruz ${ }^{1}$, and whatever his faith, he remains essentially a worshipping creature. According to the Bible, worship is the issue in the great controversy between God and Satan. The third angel's message of Rev 14:9-11 gives the most solemn warning in the Bible, a warning against false worship.

\section{Purpose of the Project}

The purpose of this project is to prepare pastoral students from the School of Theology at Montemorelos University for worship planning, leadership, and renewal in the Seventh-day Adventist Church in Mexico.

\section{Justification of the Project}

The writer teaches a course in worship in the School of Theology at Montemorelos University. The course is taught for pastoral students taking training for the degree B.A. in Theology.

${ }^{1}$ Jaime Cruz, "Worship Attitudes of Seventh-day Adventist Churchgoers at Montemorelos, Mexico." (D.Min. project report, Andrews University, 1978), 1. 
My own experience is similar to that of a large number of people in the Seventh-day Adventist Church today who were not prepared to take their place in the worship life of an Adventist congregation in a meaningful and understanding way. This is why it is urgent to have a clear understanding of the Seventh-day Adventist worship. It is incongruous that the church which recognizes doctrinally the centrality of worship in the great controversy, gives such little attention to how the church worships and the preparation of its pastors and members for worship.

My preliminary investigation of the current literature indicates a strong need to prepare pastors for worship planning, leadership, and renewal in the Seventh-day Adventist Church.

\section{Expectations of the Project}

The ultimate goal is that pastors will have a deeper and richer understanding of Adventist corporate worship. The project will prepare pastors to plan and lead Seventh-day Adventist worship services in perceptive and meaningful ways. The project will yield personal gain for me by focusing my attention on worship issues for teaching worship at Montemorelos University. It is anticipated that one outcome of this project will eventually be the preparation of a Seventh-day Adventist worship seminar for ministers and lay members in the field. The project can also be easily adapted by pastors or lay people for use as a seminar in the local church, worker's meeting, etc. This project may be a catalyst toward the development of an Adventist theology of worship. 


\section{CHAPTER II}

\section{BIBLE AND WORSHIP}

The Bible should be our starting point in our quest for a theology of worship. ${ }^{1}$ It is important for us to learn all we can from the origins and development of worship as these are revealed to us in the Scriptures. The Bible is full of teaching on worship because it is of "great importance to the living God who gave us the Scriptures."2 This investigation begins where God begins His written revelation--at creation.

Ellen G. White says that "the Bible unfolds truth with a simplicity and a perfect adaptation to the needs and longings of the human heart." ${ }^{13}$ The purpose of this chapter is to survey the biblical backgrounds which may help us in forming a theology of worship. The Scriptures are saturated with the spirit of worship.

This chapter is divided into two parts: worship in the Old Testament and in the New Testament.

${ }^{1}$ Norval F. Pease, And Worship Him (Nashville: Southern Publishing Association, 1967), 11.

${ }^{2}$ Robert G. Rayburn, O Come, Let Us Worship (Grand Rapids: Baker Book House, 1980), 43.

${ }^{3}$ Ellen G. White, Testimonies for the Church, 9 vols. (Boise, ID: Pacific Press, 1948), 5:700. 


\section{Worship in Old Testament Times}

\section{Creation}

In Gen 1:1 we are told that God "created the heavens and the earth." This is the basic reason for worship. The concreteness of God's created works implies the reality, even though God is intangible and invisible. ${ }^{2}$ Creation itself is a revelation of God. Creation also implies the reality of divine acts in the concreteness of time and space. ${ }^{3}$ God is a reality because His created works are a reality. Creation implies a free, uncoerced act of the sovereign God. ${ }^{4}$

Although God is sovereign, He manifests a grace and charity toward His creation of humanity in His image (Gen 1:27). Moreover, divine charity is implied in God's transcendence and His immanence in that while He is God and

${ }^{1}$ All Scripture quotations in this project report are from the Revised Standard Version of the Bible unless otherwise indicated.

${ }^{2}$ Oliver Koh Kan-Song, "A Proposed Order of Worship for the Seventh-day Adventist Church Informed by the Theological Presuppositions Implied in the Genesis Account of Creation and Fall of Man, and the Covenant Promise of Genesis 3:15." (D.Min. project report, Andrews University, Seventh-day Adventist Theological Seminary, 1982), 6.

${ }^{3}$ Gerhard von Rad, Old Testament Theology, 2 vols. (New York: Harper and Row, 1962), 1:139. von Rad says, "Creation is regarded as the work of Jahweh in history, a work within time. . . . It has once for all ceased to be myth."

${ }^{4} \mathrm{John}$ H. White, "Worship in the Pentateuch," in The Biblical Doctrine of Worship, ed. Edward A. Robson (Reformed Presbyterian Church of North America and Synods Committee on Worship, 1974), 3. 
man is man, He reveals Himself to and communicates with individuals in intimate ways. ${ }^{1}$

By creation we belong to God. From the very first time God created humans, He wanted to have a very special relationship with them. In His unselfish love, the Creator gave them the best of His creation so that humanity might be happy in all aspects of its life. All heaven took a deep and joyful interest in the creation of the world and of humanity. They were to live in close communion with heaven, receiving power from the Source of all power. ${ }^{2}$

God created humans as superior beings; they alone are formed in the image of God, and are capable of partaking of the divine nature, of cooperating with their Creator and executing His plans. ${ }^{3}$ Here we see the infinite love of God toward humanity; He wanted, from the very beginning, to give humans the everpresent riches of His love and to live always in His presence but by their own choice.

"In His image" implies that humans are religious and social beings seeking fellowship with God as their highest joy.

${ }^{1}$ Koh, 7.

${ }^{2}$ Ellen G. White, Sons and Daughters of God (Washington, DC: Review and Herald, 1955), 7.

${ }^{3}$ Ibid. 


\section{The Sabbath}

We may see how God reveals Himself to humankind in intimate ways when He provides the Sabbath (Gen 2:1-3). The Sabbath institution was designed to bring God and humankind together in sacred communion. According to Karl Barth, the provision of the Sabbath anticipates "a covenant of grace,"1 while Andreasen suggests that the Sabbath anticipates the incarnation which facilitates a meeting between God and humans. ${ }^{2}$

The unique threefold emphasis on the seventh day with its four different aspects at the conclusion of the Genesis creation story indicates that, just as the formation of man from the ground is the crowning act of creation physically, so the creation of the seventh day Sabbath is the crowning act of creation spiritually. Thus the Sabbath is a memorial of God's creative acts and is also significant for the future of mankind, their life and worship. ${ }^{3}$

G. H. Waterman provides the following summary:

It seems clear, therefore, that the divine origin and institution of the Sabbath took place at the beginning of the human history. At the time God not only provided a divine example for keeping the seventh day as a day of 3:98.

${ }^{1}$ Karl Barth, Church Dogmatics, 4 vols. (Edinburgh: T. \& T. Clark, 1958),

${ }^{2}$ Niels-Erik Andreasen, Rest and Redemption (Berrien Springs, MI: Andrews University Press, 1978); cf. Sakae Kubo, God Meets Man (Nashville: Southern Publishing Association, 1978), 23.

${ }^{3}$ Kenneth A. Strand, ed. The Sabbath in Scripture and History (Washington, DC: Review and Herald, 1982), 23. 
rest, but also blessed and set apart the seventh day for the use and benefit of man. ${ }^{1}$

God rests on the seventh day of Creation week in order to provide a day of meeting in rest with the crown of creation--humanity--made in His image. In resting on the Sabbath, mankind participates in God's rest, meeting with its Creator. $^{2}$

Gen 2:3 also affirms that the Creator "hallowed" the seventh day, or "sanctified it." The idea is that God made the seventh day "holy" by putting it into a state of holiness. ${ }^{3}$ The separation of the seventh day from the six working days is a gift of the Creator for all mankind.

The Creator has made the seventh day holy by separating it from the six working days and has thus provided a gift for the whole of mankind for all time. The person who keeps the seventh-day Sabbath holy follows the Exemplar's archetypal pattern (Gen 2:3) and meets with Him on that day of rest. He acknowledges his God as Creator, accepts His gift, and has a part in God's rest. ${ }^{4}$

The object of all true worship is God our Creator. The quality of worship is determined by one's conception of God and his relationship with Him. Through an awareness of God as Creator, as Lord, as Redeemer, and as Father of mankind "in His image," human's response to Him is one of worship. Hence

${ }^{1}$ G. H. Waterman, "Sabbath," The Zondervan Pictorial Encyclopedia of the Bible (Grand Rapids, MI: Zondervan Publishing, 1975), 5:183.

${ }^{2}$ Strand, 25.

${ }^{3}$ Ibid.

${ }^{4}$ Ibid., 26. 
worship is rational and inevitable. ${ }^{1}$ "How wonderful it would be if the people of God in this our day could be identified as God's own covenant people by their faithful keeping of the Sabbath." ${ }^{2}$

\section{The Altar and the Lamb}

After the entrance of sin, worship continued, but on somewhat different terms. Thus the altar and the lamb came into the picture of worship.

The experience of Cain, whose offering was not acceptable to God, is an early lesson in the fact that worship has theological significance. It is more than a mere spontaneous gesture, done by mankind in its own way. It has to be in harmony with a body of revelation which God has given to humanity. ${ }^{3}$ Cain and Abel were required to carry out a system of humble obedience, showing their reverence for God and their faith and dependence upon the promised Redeemer, by slaying the firstlings of the flock and solemnly presenting them with the blood as a burnt offering to God. ${ }^{4}$

Robert G. Rayburn provides the following idea in this respect:

We do know that God had revealed to Adam the promise of the coming Redeemer and His triumph over Satan, although even this great announcement was veiled in symbolic language (Gen 3:15). It was through the medium of sacrifice that God chose to provide for man not only a visible

${ }^{1}$ Koh, 18.

${ }^{2}$ Rayburn, 45 .

${ }^{3}$ Pease, 12.

${ }^{4}$ Ellen G. White, The Story of Redemption (Washington, DC: Review and Herald, 1947), 52. 
means of worship but also a means of comprehending at least in part those deep theological truths concerning the awful gulf which separates man in his sin from a holy God. . . . We must not forget that in the wisdom of God it was given a dominant place in the worship of the Old Testament because of the central fact of salvation history to which every sacrifice pointed, God's offering of His own Son as a sufficient sacrifice for the sins of man. ${ }^{1}$

The first altar mentioned in the Bible is that on which Noah offered his sacrifices after the Flood (Gen 8:20). However, altars may have been erected much earlier, since burnt offerings were offered from the time of Cain and Abel $($ Gen $4: 3,4){ }^{2}$

According to Ellen G. White, the sacrificial offerings were ordained by God to be to human beings a perpetual reminder and a penitential acknowledgment of their sin and a confession of their faith in the promised Redeemer. ${ }^{3}$ The altar and the sacrificial lamb were intended to impress upon the fallen race the solemn truth that it was sin that caused death.

"To Adam, the offering of the first sacrifice was a most painful ceremony. As he slew the innocent victim, he trembled at the thought that sin must shed the blood of the spotless Lamb of God." ${ }^{14}$

${ }^{1}$ Rayburn, 45, 46.

${ }^{2}$ Seventh-day Adventist Bible Dictionary (1960), s.v. "Altar."

${ }^{3}$ Ellen G. White, Patriarchs and Prophets (Mountain View, CA: Pacific Press, 1958), 68.

${ }^{4}$ Ibid. 
"Call on the Name of the Lord"

In Gen 4:26 we read a statement which probably indicates the inauguration of public worship, ${ }^{1}$ a more formal worship. ${ }^{2}$ H. C. Leupold pointed out that in this verse we have the first record of our regular worship, ${ }^{3}$ since this calling out by the use of the name definitely implies public worship. ${ }^{4}$ It should be noted that in the Old Testament "calling on the name of the Lord" frequently refers to public worship ${ }^{5}$ (note 2 Sam 6:2; 1 Chr 13:6; Pss 79:6; 116:17; Jer 10:25; Zeph 3:9).

Now the human race began to worship God, not only in private and in families, but in public and solemn assemblies. ${ }^{6}$ Or now there was so great a reformation in religion that it was, as it were, a new beginning of it. ${ }^{7}$ In the third generation the pressure of the worldly spirit upon the company of the faithful was so great that they felt obliged, as it were in self-defense, to buttress their piety by

${ }^{1}$ Lee Haines, "Genesis and Exodus," The Wesleyan Bible Commentary (Grand Rapids, MI: Wm. B. Eerdmans Publishing Co., 1967), 1:42.

2"Genesis," Seventh-day Adventist Bible Commentary, ed. F. D. Nichol (Washington, DC: Review and Herald Pub. Assn., 1953-1957), 1:244.

${ }^{3}$ H. C. Leupold, Exposition of Genesis (Grand Rapids, MI: Baker Book House, 1953), 1:228.

${ }^{4}$ Ibid.

${ }^{5}$ G. C. Aalders, "Genesis," Bible Student's Commentary (Grand Rapids, MI: Zondervan Publishing House, 1981), 1:135, 136.

${ }^{6 " G e n e s i s ~ t o ~ D e u t e r o n o m y, " ~ M a t t h e w ~ H e n r y ' s ~ C o m m e n t a r y ~(O l d ~ T a p p a n, ~}$ NJ: Fleming H. Revell Company), 1:46.

${ }^{7}$ Ibid. 
a double wall of protection, separation from their ungodly associates in the world by the formation of a distinct religious community, and by the institution of stated social worship. ${ }^{1}$

Regarding this particular experience in worship, Ellen G. White says:

The faithful had worshipped God before; but as men increased, the distinction between the two classes become more marked. There was an open profession of loyalty to God on the part of one, as there was contempt and disobedience on the part of the other. ${ }^{2}$

This is particularly worthy of notice, because Satan contrives nothing with greater care than to adulterate, with every possible corruption, the pure invocation of God, or to draw us away from the only God to the invocation of creatures. ${ }^{3}$

We may readily conclude that in Gen 4:26 the face of the church began distinctly to appear, and that worship of God was set up which might continue to posterity. ${ }^{4}$

Noah

In the days of Noah a double curse was resting upon the earth in consequence of Adam's transgression and of the murder committed by Cain. God bestowed upon the antediluvians many rich gifts; but they used His bounties to

${ }^{1}$ Thomas Whitelaw, "Genesis," The Pulpit Commentary (Grand Rapids, MI: Wm. B. Eerdmans Publishing Company, 1977), 1:92.

${ }^{2}$ White, Patriarchs and Prophets, 80.

${ }^{3}$ Calvin's Commentaries (Grand Rapids, MI: Wm. B. Eerdmans Pub. Co., 1948), 1:223.

${ }^{4}$ Ibid., 224. 
glorify themselves, and turned them into a curse by fixing their affections upon the gifts instead of the Giver. ${ }^{1}$

Humanity put God out of its knowledge and worshipped the creatures of its own imagination; and as the result, it became more and more debase. ${ }^{2}$ God could no longer bear with it, and He said, "I will destroy man whom I have created from the face of the earth" (Gen 6:13).

When Noah and his family went out of the ark after the flood, we read (Gen 8:20) that he built an altar to the Lord as a special act of worship and gratitude for the salvation of himself and his family. ${ }^{3}$

This worship followed God's revelation of Himself to Noah, and was followed by God's blessing on Noah. ${ }^{4}$ Also this incident is significant for the fact that Noah's burnt offering was made only of the "clean" animals which he had taken into the ark.

There was in this act an apparent recognition of the fact that God can accept from mankind only that which is clean and pure.

${ }^{1}$ White, Patriarchs and Prophets, 90.

${ }^{2}$ Ibid., 91.

${ }^{3}$ Rayburn, 45.

${ }^{4}$ Pease, 12.

${ }^{5}$ Rayburn, 48. 
Abraham, Isaac, and Jacob

The same pattern is evident in the Old Testament portrayal of the lives of Abraham, Isaac, and Jacob. We are able to see something of the worship of the Hebrews before the exodus. Bernard W. Anderson says that the Pentateuch took shape as a "priestly edition of Israel's sacred history." The atmosphere of worship pervades the whole work. ${ }^{2}$ Its design and religious symbolism, hallowed by centuries of worship, produced a solemn sense of the holiness and majesty of God. The Old Testament story begins with the idea of a personal God who created human beings for the purpose of communion with Himself. From the beginning, God claimed humanity and took the initiative in seeking it. ${ }^{3}$

Humanity's worship response included the building of altars and the dedication of places and objects. Ilion T. Jones has pointed out that in this period it seems clear that both the prophetic and the priestly elements are found. ${ }^{4}$ The prophetic element appears in the direct, personal approach of the individual patriarchs to God. God appeared to them, spoke to them, revealed to them His purposes, gave the insights into His character. The priestly element appears in the worship practices, insofar as they can be ascertained approximately. The

${ }^{1}$ Bernard W. Anderson, Understanding the Old Testament, $2 \mathrm{~d}$ ed. (Englewood Cliffs, NJ: Prentice Hall, 1966), 382.

${ }^{2}$ Franklin M. Segler, Christian Worship (Nashville: Broadman Press, 1967), 16.

${ }^{3}$ Ibid.

${ }^{4}$ Ilion T. Jones, A Historical Approach to Evangelical Worship (New York: Abingdon Press, 1954), 14. 
earliest group worship may have been family or tribal in nature, ${ }^{1}$ the heads of households or the tribal chiefs acting in the capacity of priests.

God appeared to Abraham and called him to leave his own country and go to a land of promise. God promised to bless Abraham, to make of him a great nation, and to make his name great (Gen 12:1-30). Abraham responded with faith and obedience, built an altar unto the Lord, and worshipped Him. Later Abraham worshipped God when he indicated his willingness to sacrifice his own son, Isaac, to the Lord (Gen 22:9-10).

Isaac learned to worship God from his father, Abraham. He built an altar and called on the name of the Lord ${ }^{2}$ (Gen 26:24-25). The theological character of his worship is noteworthy because this involves much more than may be commonly understood by such expression.

Jacob's experiences in worship were as numerous as they were glorious. He dreamed that God appeared to him through angels descending and ascending upon a ladder that reached up into heaven. In the morning he declared, "Surely the Lord is in this place; and I did not know it. . . . How awesome is this place! This is none other than the house of God" (Gen 28:16-17). He set up a stone for an altar which he dedicated to the Lord and called Bethel, "house of God."

${ }^{1}$ Ibid., 15.

${ }^{2}$ Names of the Lord: El-Elyon, God Most High; El-Shaddai, God Almighty; El-Olam, God Everlasting; and Jehova-jireh, the Lord who Provides. 
Robert G. Rayburn says:

Thus, to call upon the name of the Lord meant recognizing and believing all that is indicated in all of the various names of the Lord and worshiping Him for all the aspects of His character which these names revealed, because all are included in the one designation, the name of the Lord. ${ }^{1}$

\section{Worship from the Mosaic Age to the Exile}

Historically, the Hebrew Exodus marked the birth of Israel as a nation; prophetically, however, it was the flowering out of the Patriarchal covenant. ${ }^{2}$ The history of Israel from its historical inception in the Exodus spans more than thirteen centuries. In terms of the development of worship, it can conveniently be divided into three periods: the Sanctuary (Mosaic period), the Jerusalem Temple (Monarchical period), and the Synagogue (Exilic period).

\section{Sanctuary (Mosaic Period)}

The birth of Israel as a nation marked a great transition not only in terms of international politics but also in its national economy, social changes, and, even more so in terms of its religious life as expressed in faith and worship. ${ }^{3}$ The religious nature of Israel is indicated in Moses' formal plea to Pharaoh for the Hebrew Exodus to the effect that Israel "may worship me [God]" (Exod 4:23 NIV), "hold a festival to me [God] in the desert" (Exod 5:1 NIV), and "to offer sacrifices to the Lord our God" (Exod 5:3 NIV). That Israel was brought into

\footnotetext{
${ }^{1}$ Rayburn, 49.

${ }^{2}$ Koh, 25.

${ }^{3}$ Ibid.
} 
existence primarily to be a worshipping community is further indicated in its being covenanted as "a kingdom of priests, a holy nation" (Exod 19:6). God revealed Himself to Israel as Jehovah, the covenant God." ${ }^{11}$ With that spectacular revelation came a complex system of worship.

It is not my intent to outline Israel's complex order of worship, which in a short study like this would require an oversimplification. I, therefore, concentrate selectively on certain major aspects of Israelite worship that both maintain a continuity with the past and assert a uniqueness in forms of worship in its particular time and context.

The tent constructed in the wilderness is called "the tent of reunion." ${ }^{21}$ It is most commonly known as the tabernacle through the influence of the Vulgate. ${ }^{3}$ This is the only sanctuary that God explicitly commanded to be built (Exod 25:18).

God Himself gave to Moses the plan to that structure, with particular directions as to its size and form, the materials to be employed, and every article of furniture which it was to contain. The holy places made with hands were to be "figures of the true," "patterns of things in the heavens" (Heb 9: 23, 24)--a miniature representation of the heavenly temple where Christ, our great High Priest, after offering His life as a sacrifice, was to

${ }^{1}$ Segler, 17.

${ }^{2}$ Roland de Vaux, Ancient Israel: Its Life and Institutions, 2 vols. (New York: McGraw-Hill Book Co., 1965), 294.

${ }^{3}$ Eduardo Zurita, "Toward a Theology of Seventh-day Adventist Meeting Place, with a Study of Practical Implications and Applications Thereof" (D.Min. project, Andrews University, 1984), 6. 
minister in the sinner's behalf. . . . Devotion to God and a spirit of sacrifice were the first requisites in preparing a dwelling place for the Most High. ${ }^{1}$

The intimate personalism and reality of God are made manifest in concreteness through a sanctuary structure symbolizing "the presence of God"2 among His people. The tabernacle was seen as an expression of the antithesis between Israel and the surrounding culture. Worship set Israel apart from the worship conducted by pagans and accented their relationship to Yahweh. Thus, the tabernacle and the temple became the visible and tangible signs of Israel's relationship to God. ${ }^{3}$

The theology of the Old Testament shows that the special place in which God is present is in the hearts of the people who invoke Him. It is with His people that He dwells, wherever that people is to be found. And if it is true that there are sacred spots, this is not to suggest that God is exclusively localized there, but to show that God intervenes in the world and claims the whole earth as His own; it is to show also that God calls His people to meet Him on this earth. ${ }^{4}$

The sanctuary structure together with its furnishings provides further revelation of God's nature, character, and ministry. ${ }^{5}$ The sharp antithesis between

${ }^{1}$ White, Patriarchs and Prophets, 343.

${ }^{2}$ Robert E. Webber, Worship Old and New (Grand Rapids, MI: Zondervan Publishing House, 1982), 25.

${ }^{3}$ Ibid.

${ }^{4}$ J. J. von Allmen, Worship: Its Theology and Practice (New York: Oxford University Press, 1965), 245.

${ }^{5}$ Koh, 27. 
God and depraved humanity, between righteousness and sinfulness, is discernible in the design of the furnishing in the sanctuary.

According to Gerhard von Rad, the imageless worship of Israel distinguishes it as a unique worshipping community among surrounding nations, and indeed "a stranger and sojourner among the religions."

Significantly the ministration of divine atoning, redeeming, and sustaining grace as expressed in the symbolisms of the ark, the shewbread, and the lampstand is not made visible to a worshipper except through a mediating priest. The sacrifices and offerings that issue from covenant "are all parables of the holiness and justice of God."2

\section{The priesthood}

By divine direction the tribe of Levi was set apart for the service of the sanctuary. In the earliest times every man was the priest of his own household. ${ }^{3}$ The patriarchs, as heads of families or tribal groups, performed what we would consider specific priestly functions. ${ }^{4}$ In the days of Abraham the priesthood was regarded as the birthright of the eldest son. Now, instead of the firstborn of all

'von Rad, 1:214.

${ }^{2}$ William Dyrness, Themes in the Old Testament Theology (Downers Grove, IL: InterVarsity Press, 1979), 94.

${ }^{3}$ White, Patriarchs and Prophets, 350. 6.

${ }^{4}$ Raymond E. Brown, Priest and Bishop (New York: Paulist Press, 1970), 
Israel, the Lord accepted the tribe of Levi for the work of the sanctuary. ${ }^{1}$ Aelred Cody also indicates that the "earliest glimpse of priesthood in Israel" ${ }^{\text {"2 }}$ is provided by the story of the Levite. That this "institution of cultic prophecy"3 was practiced in Israel with little change after the settlement in Palestine is clear from the available evidence.

In these sources a priest appears to be, above all, a kind of aedituus, the minister, keeper, or attendant of a sanctuary and of the sacral objects kept in the sanctuary. ${ }^{4}$ Raymond E. Brown points out that the professionalism of the tribe of Levi resulted eventually in an exclusively Levitical priesthood. ${ }^{5}$

The Levitical priesthood, although it was not a vocation in our sense, did not lack an ideal of sanctity. The priest was sanctified for and by his work; he had to be holy in order to handle the things that belonged to God. If the whole nation was under the command, "You shall be holy; for I the Lord your God am holy" (Lev 19:2), a special holiness was demanded of the priest because he served God in a special way. God instructed Moses, "You shall consecrate him, for he offers the bread of your God; he shall be holy to you; for I the Lord, who sanctify

${ }^{1}$ White, Patriarchs and Prophets, 350.

${ }^{2}$ Aelred Cody, "Priesthood in the Old Testament," Studia Missionalia (Rome: Gregorian University Press, 1973), 22:310.

${ }^{3}$ E. O. James, The Nature and Function of Priesthood (London: Thames and Hudson, 1955), 73.

${ }^{4}$ Cody, 311 .

${ }^{5}$ Brown, 6. 
you, am holy" (Lev 21:8). Since the holiness of God Himself is connected with His being apart, a major aspect of the holiness of the priest consisted of his separation from the secular or profane. Greater purity was demanded of him in his general contacts with society, but the demand for purity and noncontamination was especially stringent during the time when he exercised priestly service at the sanctuary. The priest had to wash himself and wear special garments when he took part in sacrifice. ${ }^{1}$

Not only the sanctuary itself, but the ministration of the priests was to "serve unto the example and shadow of heavenly things" (Heb 8:5). Thus it was of great importance, and the Lord, through Moses, gave the most definite and explicit instruction concerning every point of this typical service. ${ }^{2}$

Perhaps it is worth noting that the holiness of separation demanded of Israelite priests did not make religion at all remote from the lives of the people; in its own way Israel exemplified a better harmony of religion and the world than has been found in the church. ${ }^{3}$

It may be reported that the Old Testament ideal of the priesthood was not entirely idealistic. If a man was born into the priestly tribe, he had to be installed in the priestly office.

${ }^{1}$ Ibid., 8.

${ }^{2}$ White, Patriarchs and Prophets, 351, 352.

${ }^{3}$ Brown, 9. 
Tradition declares that the priesthood is one of the "strongest calls to perfection." ${ }^{11}$ The priest is God's instrument. God does His work through him.

Services

The ministration of the sanctuary consisted of two divisions, a daily and a yearly service.

The daily service. This service was performed at the altar of offering in the court of the tabernacle and in the holy place. The service consisted of the morning and evening burnt offerings, the offering of sweet incense on the golden altar, and the special offering for individual sins. And there were also offerings for Sabbaths, new moons, and special feasts. ${ }^{2}$ Every morning and evening a lamb of a year old with its appropriate meat offering, was burned upon the altar, thus symbolizing the daily consecration of the nation to Jehovah, and its constant dependence upon the atoning blood of the Christ who was to come.

As the priests entered the holy place each morning and evening at the time of incense, the daily sacrifice was ready to be offered upon the altar in the court without. This was a time of intense interest to the worshippers who assembled at the tabernacle.

\footnotetext{
${ }^{1}$ Jacques Leclercq, Man of God for Others (New York: Newman Press, 1968), 7.
}

${ }^{2}$ White, Patriarchs and Prophets, 352. 
The most important part of the daily ministration was the service performed on behalf of individuals. The repentant sinners brought their offering to the door of the tabernacle, and, placing their hands upon the victim's head, confessed their sins, thus in figure transferring them from themselves to the innocent sacrifice. By their own hand the animals were slain, and the blood was carried by the priest into the holy place and sprinkled before the veil, behind which was the ark containing the law that the sinners had transgressed.

The yearly service. Once a year, on the Day of Atonement, the priest entered the most holy place for the cleansing of the sanctuary. The work there performed completed the yearly round ministration. Ellen G. White says that:

On the Day of Atonement two kids of the goats were brought to the door of tabernacle, and lots were cast upon them, "one lot for the Lord, and the other lot for the scapegoat." The goat upon which the first lot fell was to be slain as a sin offering for the people. And the priest was to bring his blood within the veil, and sprinkle it upon the mercy seat. "And he shall make an atonement for the holy place, because of the uncleanness of the children of Israel, and because of their transgressions in all their sins: and so shall he do for the tabernacle of the congregation, that remaineth among them in the midst of their uncleanness." "And Aaron shall lay both his hands upon the head of the live goat, and confess over him all the iniquities of the children of Israel, and all their transgressions in all their sins, putting them upon the head of the goat, and shall send him away by the hand of a fit man into the wilderness: and the goat shall bear upon him all the iniquities unto a land not inhabited." Not until the goat had been thus sent away did the people regard themselves as freed from the burden of their sins. Every man was to afflict his soul while the work of atonement was going forward. All business was laid aside, and the whole congregation of Israel spent the day in solemn humiliation before God, with prayer, fasting, and deep searching of heart. ${ }^{1}$

${ }^{1}$ Ibid., 355 . 
The liturgical act of the high priest sprinkling blood upon the ark and upon the altar of burnt offering (Lev 16:14; 18-19), thus making atonement for himself, his household, and the whole nation (Lev 16:17), magnified the meaning of the substitutionary atoning nature of the sacrifice as a substitute of "the part for the whole, one for the many."1

During the Day of Atonement Israel humbled itself and rested from its activity. It had to rely on Yahweh's power and forgiving grace. While Israel rested Yahweh was active, removing sin and impurity from His sanctuary. ${ }^{2}$ The importance of His people allowed Him to reveal His power over all demonic forces. He did not need to be protected from them. ${ }^{3}$ The Day of Atonement was a proclamation of Yahweh's sovereignty! ${ }^{4}$

${ }^{1}$ Dyrness, 157.

${ }^{2}$ Angel Manuel Rodríguez, "Substitution in the Hebrew Cultus and in Cultic Related texts" (Th.D. dissertation, Andrews University, 1979), 120.

${ }^{3}$ Baruch A. Levine, In the Presence of the Lord (Leiden: E. J. Brill, 1974), 74.

${ }^{4}$ Rodríguez, 120. 
Jerusalem Temple (Monarchical Period)

The establishment of the monarchy in Israel proved in a certain sense to be the victory of Yahweh. ${ }^{1}$ The nation now recognized definitely and finally that for them He was the supreme God. ${ }^{2}$

In the historical books the king appears several times as the leader in worship, for he was a sacred person, sanctified by his anointing and adopted by Yahweh. $^{3}$ At this point may be noticed the great significance for religion of the figure of the theocratic king. Such a reign as that of David completely manifested the compatibility of monarchy with the idea of a theocracy. This result was no doubt entirely due to David's personal example and ascendancy. ${ }^{4}$ Prophets and priests instinctively rallied to his side, ${ }^{5}$ and he himself, in spite of grave faults of character, was conspicuous in his devotion to the service of Jahweh. Hence a unique significance was attached to the reign of David, and the prophets identified the future fortunes of the monarchy with those of David's house. ${ }^{6}$

${ }^{1}$ W. O. E. Oesterley and Theodore H. Robinson, Hebrew Religion: Its Origin and Development (New York: Mcmillan Company, 1937), 195.

${ }^{2}$ Ibid.

${ }^{3}$ Segler, 18 . 1905), 61 .

${ }^{4}$ R. L. Ottley, The Religion of Israel (Cambridge: The University Press,

${ }^{5}$ Such passages as 2 Sam 3:9, 18; 5:2; 7:5 show that David was the center of high prophetic hopes. On the other hand, it was the task of men like Gad and Nathan to rebuke the sins of the monarch and to guide his conscience. They were in fact 'prophets' in the higher sense of the word.

${ }^{6}$ Ottley, 62. 
In fact, the rise of the messianic hope in its strict sense connected itself with the line of David and with the special promise vouchsafed to him by Jahweh. In the light of that promise his successors on the throne of Judah were transfigured. The reigning monarch was invested with ideal attributes as the visible representative of Jahweh's sovereignty. His throne was Jahweh's throne (1 Chr 29:23), and each monarch was in his degree a type of the coming Messiah. ${ }^{1}$ In this connection the building of the temple at Jerusalem by Solomon was an event of peculiar importance. Thereby the religious policy of David reached its climax. The temple was a national sanctuary where both king and people, rich and poor, could offer praise and sacrifice to Jehovah. ${ }^{2}$ Many people came daily to the temple. ${ }^{3}$

God did not permit David to build the temple, but He promised that Solomon, David's son, would have the honor of building the house for the name of the Lord. ${ }^{4}$ The long-cherished plan of David to erect the temple to the Lord, Solomon wisely carried out. ${ }^{5}$ For seven years Jerusalem was filled with busy workers engaged in leveling the chosen site, in building vast retaining walls, in

${ }^{1}$ Ibid.

${ }^{2}$ Zurita, 9 .

${ }^{3}$ There is a description of the temple and its furnishings in $1 \mathrm{Kgs} 6$ and 7 and in $2 \mathrm{Chr} 3$ and 4.

${ }^{4}$ Rayburn, 75 .

${ }^{5}$ Ellen G. White, Prophets and Kings (Mountain View, CA: Pacific Press Publishing Association, 1973), 11. 
laying broad foundations, "great stones, costly stones, and hewed stones," in shaping the heavy timbers brought from the Lebanon forest, and in erecting the magnificent sanctuary (1 Kgs 5:17).

The temple was the most magnificent and elaborate of Israel's holy places dedicated to the worship of God. ${ }^{1}$ It is considered one of the wonders of the ancient world. ${ }^{2}$

At the dedication of the temple, King Solomon played a leading role in the procession of the ark to the temple ( $2 \mathrm{Chr} 5: 6 ; 7: 5)$, the officiation of the sacrifices and offerings ( $2 \mathrm{Chr} 5: 6 ; 7: 5)$, the installation of the ark in the temple, the pronouncement of blessing upon the assembly ( $2 \mathrm{Chr} 6: 3)$, and the offering of the dedicatory prayer ( $2 \mathrm{Chr} 6: 14-22)$. Then "fire came down from heaven and consumed the burnt offering and the sacrifices, and the glory of the Lord filled the temple" (2 Chr 7:1). And the Israelites knelt and worshipped the Lord ( $2 \mathrm{Chr}$ 7:3). This worship event became a national memory.

The dedication of Solomon's temple was not a ceremony established by law. ${ }^{3}$ It was done in accord with that reverence which should always be associated with buildings which are set apart especially for divine worship.

Monarchical worship distinguishes itself not only with its splendid liturgical embellishment but more so with the leading role of the king in worship.

\footnotetext{
${ }^{1}$ Segler, 18.

${ }^{2} \mathrm{Koh}, 36$.

${ }^{3}$ Rayburn, 76.
} 
The king was the "priestly person par excellence."1 He was regarded as belonging to the order of Melchizedek, the priest-king of God Most High (Ps 110:4; cf. Gen 14:18), the anointed of the Lord (cf. 1 Sam 24:10; Ps 2:2), the son of God (Ps 2:7). He thus ruled the nation in God's name and led out in worship as God's priest. In this special relationship with God, the king was really "the psychic center" of the life of Israel. ${ }^{2}$ The king of Israel as a son of God implied God is the true King. Hence the Psalmist sings, "For God is the King of all the earth; sing to him a psalm of praise" (Ps 47:7 NIV). Thus to Israel under the monarchy, God was not only Creator and Redeemer, but also King and therefore Lord over all.

The worship of the Lord's people during the reign of David was organized upon a grand scale. It became even more magnificent after Solomon's temple was completed. Great choirs trained under professional musicians provided sublime music for the awe-inspiring services of worship. It was only in the splendor of the ceremony that the worship of the temple was different from that of the tabernacle..$^{3}$ The same sacrifices, offerings, and feasts were observed. the emphasis upon worship through, both instrumental and vocal, seems to be the only added element. God introduced this emphasis largely through the poetic and musical gifts which He had given His servant King David. We do not know how

\footnotetext{
${ }^{1}$ A. H. Herbert, Worship in the Ancient Israel (Richmond, VA: John Knox Press, 1959), 23.

${ }^{2}$ Ibid., 34 .

${ }^{3}$ Rayburn, 76.
} 
David's music sounded, but his inspired Psalms are still an integral part of our services of worship.

The theology of monarchical worship can well be summed up in cultic hymn in Ps 96 (NIV). The psalmist worships God exhorting, "O worship the Lord in the splendor of his holiness; tremble before him all the earth" (vs. 9). For God is the Redeemer (vss. 2-3), the Creator (vs. 5), the King (vs. 10), the Judge (vss. 10, 13). He is great and most worthy (vs. 4), holy (vs. 9), glorious (vs. 8), sovereign (vs. 10), just, true, and righteous (vss. 10, 13). Man's response is to worship God in the splendor of His holiness (vs. 9), in praise of His salvation (vss. 4-5), with an offering to His glory (vs. 8), with proclamation of His marvelous redemptive deeds (vs. 3), and with trembling and fear because the Lord is in the sanctuary (vs. 6). In this great cultic hymn are found all the basic ingredients of true worship.

Worship carries with it a blessing as well as a judgment. When Israel worshipped God in love and obedience, God communed with His covenant people in full glory and splendor. When Israel perverted its worship, God repeatedly warned of the destruction of the temple (Jer 7:12-14) and of the nation (Jer 17:34). The Lord is the Holy One of Israel. ${ }^{1} \mathrm{He}$ is "righteous in all his ways" (Ps 145:17), and "holy and awesome is his name" (Ps 111:9 NIV).

${ }^{1}$ The term "Holy One" is used at least 30 times in Isaiah alone. It is also found in Ps 71:22; Jer 50:29. The idea of holiness is permeated in Israel's faith and worship. 
The Synagogue (Exilic Period)

The history of Israel from its conquest of Canaan to the captivity was marked by a constant struggle regarding worship. ${ }^{1}$ The warning of the horror of the destruction of the Jerusalem temple became a tragic reality in 586 B.C. The cream of the Jewish population was deported to Babylon. All sacrificial worship was suspended. The Jews in Babylon found themselves completely cut off from communion with God. And "by the rivers of Babylon we (the exiles) sat and wept, when we remembered Zion" (Ps 137:1 NIV).

All his life Jeremiah had predicted tragedy. ${ }^{2}$ But as the people began to realize that he was right and their case was desperate, he began to reach out toward a more remote future. And in this time of despair he constantly preached that there was still a glorious future for Israel. ${ }^{3}$

In Babylon the priests and Levites became, for all intents and purposes, laymen. ${ }^{4}$ They could not sacrifice; they were not part of the priestly body which administered the temple. ${ }^{5}$ In practice and association they were a part of the general body of the Jews in Babylon.

${ }^{1}$ Pease, 15.

${ }^{2}$ Bernard J. Bamberger, The Story of Judaism (New York: Schocken Books, 1970), 34.

${ }^{3}$ Ibid.

${ }^{4}$ John Punnet Peters, The Religion of the Hebrews (Cambridge: Harvard University Press, 1932), 381.

${ }^{5}$ Ibid. 
Having accepted the theological interpretations of their calamity, the Jews once again turned toward God to worship. But worship in that traumatic experience struggled to find its true center and reality in the wake of the absence of the temple, the sacrificial cult, and the hereditary priesthood. A unique phenomenon, the synagogue, arose not to be a substitute for the temple, says Herbert, but to coordinate faith and worship of the exiles. ${ }^{1}$

The origin of the synagogue is obscure, and documentable certainty is not available. $^{2}$ It probably began first in one another's homes, meeting in order to keep their faith alive. ${ }^{3}$ Another scholar characterizes the synagogue worship as an exilic survival agency, with its prime intention of preserving the Jewish identity through a corporate memory of God's great deeds for them in the past. ${ }^{4}$ Lewis Finkelstein says that the synagogue probably originated as a result of the destruction of Jerusalem and the temple and the subsequent dispersion of the

${ }^{1}$ Herbert, 31.

${ }^{2}$ Phillip Sigal, Judaism: The Evolution of Faith (Grand Rapids, MI: Wm. B. Eerdmans Publishing Association, 1988), 96.

${ }^{3}$ H. H. Rowley, The Faith of Israel (London: SCM Press, 1956), 224.

${ }^{4}$ James F. White, Christian Worship in Transition (Nashville: Abingdon, 1976), 12. White further notes that "Judah could survive through worship, though countless other conquered kingdoms perished completely. Worship could overcome even fire and sword," ibid. 
Jewish people during the exile. ${ }^{1}$ Thus it was an intertestamental phenomenon and not strictly an institution of the Old Testament. ${ }^{2}$

Perhaps the most important part of the Old Testament hope which developed before the New Testament era was the Jews' dependence upon God's love and mercy. ${ }^{3}$ Even as they lived in the present, they looked forward to whatever future He would provide.

In each of these parts of the Old Testament faith, which came before the New Testament era, God was setting the stage for His new thing. At times this faith was cloudy; at times it was more clear. However, through every instance, He was setting the stage for the development of the Christian Church. Jesus and His disciples walked upon the stage of history, one of whose major supports was the faith of the Old Testament. ${ }^{4}$

The final root which fed into the growth of the New Testament era was Judaism. Of all the external influences which shaped the thinking and actions of the first disciples, none was probably as significant as Judaism itself. ${ }^{5}$

${ }^{1}$ See Lewis Finkelstein, "The Origin of the Synagogue," Proceedings of the American Academy for Jewish Research 1 (1928-30): 49-59; 2 (1931): 69-81.

${ }^{2}$ Webber, 27.

${ }^{3}$ Robert L. Cate, A Story of the New Testament and Its Times (Nashville: Broadman Press, 1991), 62.

${ }^{4}$ Ibid.

${ }^{5}$ Ibid., 95. 


\section{Worship in New Testament Times}

The first disciples were Jews by birth and upbringing, and it is probable that they would bring into the new community at least some of the religious usages to which they had long been accustomed. ${ }^{1}$ Christianity came out of Judaism. It is not surprising to discover in the New Testament that from the beginning the early church worshipped in the temple area and possibly also in the synagogue of Jerusalem. ${ }^{2}$ It is also no surprise that this very remarkable institution, the synagogue, has influenced Christian worship for nearly 2000 years. According to Josephus, in the edict of the Emperor Augustus "the synagogue is called house of the Sabbathkeeping."

By the beginning of the first century A.D., the synagogue ${ }^{4}$ was a

${ }^{1}$ Ralph P. Martin, Worship in the Early Church (Grand Rapids, MI: Wm. B. Eerdmans Publishing Company, 1975), 19.

${ }^{2}$ According to the Talmud (TJ Meg. 3:1) the number of synagogues in Jerusalem at the time of the destruction of the temple in A.D. 70 was 480. Another quotation (TB ket. 105a) indicates that the number was 394 .

${ }^{3}$ Josephus Antiquities of the Jews 16.6 .2 (trans. William Whiston, Kregel Publications, 344).

${ }^{4}$ Some take the position that Ps $74: 8$ is an identification of an early origin of the synagogue. Nevertheless, the RSV and NASB translate this text as "meeting places." Perhaps these meetings places were the "old country sanctuaries" of Israel. See Donald E. Gowan, Bridge Between the Testaments (Philadelphia: Fortress Press, 1967), 214-27; A. A. Anderson, The Book of Psalms, NCBC, vol. 7 (Grand Rapids, MI: Wm. B. Eerdmans Pub., Co., 1972), 541. 
well-established institution, not only in Jerusalem, but around the Mediterranean world, as the New Testament testifies. ${ }^{1}$

The revelation of God as residing with the exiles and the provision of the Sabbath as "His sanctuary in time"2 both provide the basis of worship and communion despite the absence of a temple and sacrifice. The phenomenon of the synagogue, through its corporate memories of God's great acts for Israel, attempts to preserve the identity and faith of Israel during the captivity.

The circumstances of captivity reduced worship and faith to the essence, that faith and worship is primarily a matter of the heart relationship with the personal God. The simple recital of God's deeds in the reading of the Torah enhanced afresh the objective reality of God and the subjective faith and gratitude of the people in the present help of the Lord. The implication of the captivity points from the temporal character of the Old Testament worship to an ultimate reality in the coming Suffering Servant of the Lord. ${ }^{3}$

\section{The Roman Root}

At the beginning of the New Testament era, the Mediterranean world was enjoying the famous pax Romana, the peace of Rome. Insofar as Judea was

${ }^{1}$ Zurita, 19.

${ }^{2}$ Samuele Bacchiocchi, Divine Rest for Human Restlessness (Rome: Pontifical Gregorian University Press, 1980), 88.

${ }^{3} \mathrm{Koh}, 44$. 
concerned, this was the first time real peace had settled over the region since the beginning of the Maccabean revolt (168 B.C.). ${ }^{1}$

The peace of Rome also brought a certain degree of prosperity to the region. Highways allowed trade to flow and massive building projects were undertaken at the direction of Rome. Further, at least along the highways, Roman patrols kept outlawry under good control. Pilgrims, refugees, and merchants were able to travel from one end of the empire to the other with relative ease and security.

The peace of Rome was no gentle peace. The occupying forces of Rome cost money. This meant that taxes were an ever-present reality. Taken at its best, the peace which Rome brought was that of a military dictatorship. Peace could be enjoyed only at the price of utter submission to the will and whim of the dictator.

\section{The Birth of Christ}

The birth of Christ saw the lands which surrounded the Mediterranean in the possession of Rome. Yet with all its unity of imperial authority and military control, Rome was far from crushing local institutions. In domestic matters the inhabitants of the provinces were largely self-governing. ${ }^{2}$ Their local religious observances were generally respected. Among the masses the ancient languages

${ }^{1}$ Cate, 108 .

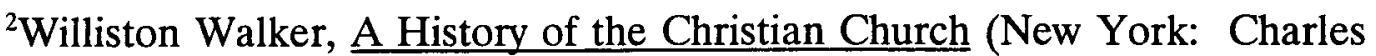
Scribner's Sons, 1970), 3. 
and customs persisted. Even native rulers were allowed a limited sway in portions of the empire. Such a land was Palestine at the time of Christ's birth. The diversity was nowhere more apparent than in the realm of religious thought.

Christianity entered no empty world. Its advent found men's minds filled with conceptions of the universe, of religion, of sin, and of rewards and punishments, with which it had to reckon and to which it had to adjust itself. ${ }^{1}$ Christianity could not build on virgin soil. The conceptions which it found already existing formed much of the material with which it must erect its structure. ${ }^{2}$

A profound sense of unworthiness, of ill desert, and of dissatisfaction with the existing conditions of life characterized the mass of humankind. The varied forms of religious manifestations were evidences of the universal need of better relations with the spiritual and unseen, and humanity's longing for help greater than any they could give one another.

Besides these general conceptions common to popular religion, the world into which Christianity came owed much to the specific influence of Greek thought. Hellenistic ideas dominated the intelligence of the Roman Empire, but their sway was extensive only among the more cultivated portion of the population.

In summing up the situation in the heathen world at the coming of Christ, one must say that however simple the beginnings of Christianity may have been,

${ }^{1}$ Ibid.

${ }^{2}$ Ibid., 4. 
Christianity needed to overcome all those situations if it was to conquer the Roman Empire or become a world religion.

\section{Worship in the Synagogue}

The early Christian Church took over the synagogue forms of worship in large measure. ${ }^{1}$ The first Christians were Jews, brought up from childhood in the worship of the synagogue. ${ }^{2}$ In the synagogue the regular Sabbath service called for the Shema (which was a sort of Hebrew Creed); some music; eighteen or nineteen prayers, often reduced to six in practice; the reading of the lesson from the Law, and one from the Prophets; and the exposition of the Scriptures. ${ }^{3}$

The synagogue had become the main focus of religious life for most Jews. ${ }^{4}$ Robert M. Seltzer points out that the synagogue was a center of communal prayer and learning where the Bible was read, translated into vernacular Aramaic, and interpreted. ${ }^{5}$

Franklin M. Segler points out that worship in the synagogue differed a great deal from worship in the temple: (1) synagogue worship was less formal; (2)

${ }^{1}$ W. O. E. Oesterley, The Jewish Background of the Christian Liturgy (Oxford: Clarendon Press, 1925), 11.

${ }^{2}$ Raymond Abba, Principles of Christian Worship (New York: Oxford University Press, 1957), 15.

${ }^{3}$ Andrew W. Blackwood, The Fine Art of Public Worship (New York: Abingdon-Cokesbury Press, 1939), 41.

${ }^{4}$ Robert M. Seltzer, Jewish People, Jewish Thought: The Jewish Experience in History (New York: Macmillan Pub. Co., 1980), 215.

${ }^{5}$ Ibid., 215, 216. 
the didactic or teaching element was foremost in the synagogue; (3) priestly functions were not as prominent; (4) the teacher was the central figure in the synagogue; and (5) lay participation was more prominent. ${ }^{1}$

The chief elements of synagogue worship have been outlined by Oesterley as follows: (1) reading of the Scripture and their interpretation; (2) recitation of the Jewish creed, the Shema (Deut 6:4); (3) the use of the Psalms, the Ten Commandments, the Benediction, and the Amen; (4) the prayers; and (5) the Jewish Kedushah, or prayer of sanctification, which became in the Christian tradition the Ter Sanctus ("Holy, Holy, Holy"). ${ }^{2}$ All that is needed for a synagogue gathering is ten male adults, a Torah, and a leader.

Robert Rayburn rightly points out that the New Testament offers only the barest glimpse into the service of worship conducted by the apostles. ${ }^{3}$ The synagogue liturgy is considered by Cyril Richardson a lay liturgy in which the worshipper can be called to lead out in any part of the service. ${ }^{4}$ In Jesus' experience and Paul confirmed this. At the synagogue of Nazareth, Jesus was called to read. He opened to Isa 61:1-2, read, and sat down to preach (Luke 4:16-28). Paul and his companions were invited to explain the reading (Acts 13:15) by the officials of the synagogue.

${ }^{1}$ Segler, 26.

${ }^{2}$ Oesterley, chap. 2 .

${ }^{3}$ Rayburn, 77.

${ }^{4}$ Cyril Richardson, "Worship, etc.," Interpreter's Dictionary of the Bible (1962), 4:883-84. 


\section{Worship in the Temple}

The temple of Christ's day was the one great link with the worship of Israel's past. Its services were reminiscent of the tabernacle and Solomon's temple. Jesus' acquaintance with the center of worship began in childhood and continued throughout His life. Often He taught in its courts and attended its services. He even paid the temple tax. ${ }^{1}$

The Gospel according to John indicates that Christ's public ministry began with the cleansing of the temple, properly the Court of the Gentiles (John $2: 14,15)$. It was in this memorable occasion that Jesus proclaimed that the temple in Jerusalem was "His Father's house" and that it had been made by the dealers a "house of trade" (John 2:16).

It is important to notice in this text that the objection of Jesus was "not to their dishonesty, but to their presence." ${ }^{2}$ In other words, Christ's action was not an attack on the sacrificial system. His deep concern was for the respect due to His Father's house, and for those Jews or Gentiles who wished to pray or worship in peace in the Court of the Gentiles. ${ }^{3}$

The four Gospels are unanimous in indicating that Jesus used the temple's courts to teach the people (Matt 26:55; Mark 12:35; 14:49; Luke 20:1; 21:37, 38;

${ }^{1}$ Pease, 18.

${ }^{2}$ Leon Morris, The Gospel According to John, NICNT, 11 vols. (Grand Rapids, MI: Wm. B. Eerdmans Pub. Co., 1971), 4:195.

${ }^{3}$ Zurita, 13. 
22:52, 53; John 7:14, 28; 8:2, 20; 18:20). However, neither John nor the Synoptics indicate that Jesus or His disciples offered any sacrifice in the temple.

Jesus' attitude toward the temple and its worship was expressed most vividly in His sayings concerning the destruction of the city of Jerusalem and the temple and His final action in the Court of the Gentiles.

The temple was the great pride of all Jews, including the disciples of Jesus. Luke observes that the Christians were continually in the temple blessing God (Luke 24:53). After Pentecost they were found in the temple day by day continuing steadfastly in prayer (Acts 2:46). The apostles continued to teach daily in the temple (4:1 ff.). Although Paul attended the temple for ceremonial purposes (21:26), he proclaimed that "The God who made the world and everything in it is the Lord of heaven and earth and does not live in temples built by hands." Jesus Himself had predicted, "The hour is coming when neither on this mountain nor in Jerusalem will you worship the Father" (John 4:21). The Christians no longer needed the temple in Jerusalem, for Christ Himself had become their temple, their place for meeting God in worship. Paul saw the church as a "holy temple" in the Lord (Eph 2:14, 21). ${ }^{1}$

When Jesus hung on the cross, the temple's veil was torn from top to bottom. The service of the temple had served its purpose. The symbol had come to reality. From that time on every person could approach God directly, without the ministration of a priest. This experience was not limited by geography, but

${ }^{1}$ Segler, 25. 
could take place wherever individuals approached God "in spirit and in truth."

This tremendous truth had great implications for divine worship. Temples, altars, animal sacrifices, priests, vestments--"God could do no more for man through these channels. The whole system must be swept away." "Christ's work was to established an altogether different worship."2

Ellen G. White further develops the meaning of this "altogether different worship" by stating:

Not by seeking a holy mountain or a sacred temple are men brought into communion with heaven. Religion is not to be confined to external forms and ceremonies. The religion that comes from God is the only religion that will lead to God. In order to serve Him aright, we must be born of the divine Spirit. This will purify the heart and renew the mind, giving us a new capacity for knowing and loving God. It will give us a willing obedience to all His requirements. This is true worship. Wherever a soul reaches out after God, there the Spirit's working is manifest, and God will reveal Himself to that soul. For such worshipers He is seeking. He waits to receive them, and to make them His sons and daughters. ${ }^{3}$

\section{Worship in the Apostolic Age}

At the close of the Master's life, He employed three symbols which have been used by Christians in their worship. The first two, the bread and the wine, are used by nearly every Christian communion. The third, the washing of feet and the towel, is used by only a few. These symbols are eloquent in their simplicity.

${ }^{1}$ Ellen G. White, The Desire of Ages (Nashville: Southern Publishing Association, 1898), 36.

${ }^{2}$ Ibid., 157.

${ }^{3}$ Ibid., 189. 
Bread and wine speak to us of nourishment, and the towel of cleansing. ${ }^{1}$ These are almost as fundamental as the original symbol of time on which worship was founded at the dawn of creation. Truly Jesus set a new pattern for worship, a pattern that departed from the Old Testament system which had served its purpose. $^{2}$

It is quite clear that early in the apostolic period the apostles and the Jewish Christians continued to worship in the temple in Jerusalem. ${ }^{3}$ This would be for a twofold purpose--to receive instruction from the apostles and to take part in the temple worship. ${ }^{4}$ They had no feeling, as yet, that they ought to break with the old religion, as though it had been superseded by the new. They simply continue their old habits of Jewish worship; retained the Jewish practice of stated prayers, morning, afternoon, and at sunset; feeling that these, so far as they went, provided a worthy vehicle for their Christian devotions. ${ }^{5}$

Oscar Cullmann writing in this respect says that:

In the first part of the Book of Acts we find that the first Christians gathered in the Temple (2:46 and 5:42; also Luke 24:53) in accordance with the Jewish custom, just as Jesus himself in Jerusalem had taught daily in the Temple (Mark 14:49). . . . But we hear also how the gathering of the Christian community were growing above and beyond the limits of their

${ }^{1}$ Pease, 21.

${ }^{2}$ Ibid.

${ }^{3}$ Alexander B. McDonald, Christian Worship in the Primitive Church (Edinburgh: T. \& T. Clark, 1935), 58.

${ }^{4}$ Ibid.

${ }^{5}$ Ibid., 59. 
Jewish setting; for at the same time the disciples were coming together in particular houses. ${ }^{1}$

D. H. Hislop points out that "the influence of the synagogue is direct and obvious." ${ }^{2}$ The Christian Church took from it the reading of the Old Testament Scripture, the practice of prayer, and the homily; this formed what a later age called the liturgy of the catechumens. ${ }^{3}$

While the first Christians continued to worship for a time in the temple and the synagogue, it must here be observed that the fundamental basis of their worship was what God had accomplished in His Son Jesus Christ.

Their celebration meant living by the saving deeds of Jesus in fellowship with the Risen One in the expectation of His parousia. ${ }^{4}$ But, the resurrection, by itself, does not explain the origin of the church, for the important thing to remember here is not that a Man somehow was raised from the dead. The supremely significant fact about the resurrection experience is that "this Jesus" who died on the cross because of our sins is the One who is alive forevermore. ${ }^{5}$

${ }^{1}$ Oscar Cullman, Early Christian Worship (Chicago: Henry Regnery Company, 1953), 9. 1935), 62.

${ }^{2}$ D. H. Hislop, Our Heritage in Public Worship (Edinburgh: T. \& T. Clark, ${ }^{3}$ Ibid.

${ }^{4}$ Gerhard Delling, Worship in the New Testament (Philadelphia: Westminster Press, 1962), xii.

${ }^{5}$ Richard M. Pope, The Church and Its Culture (St. Louis, MO: 1965), 34. 
At the heart of the gospel that created the church was the account of the execution, the crucifixion, and the resurrection of this Man. ${ }^{1}$ "We preach Christ crucified," the Apostle wrote (1 Cor 1:23) and declared that He had purchased the church "with his own blood" (Acts 20:28).

No exact order can be found in the worship of this apostolic era, but the following elements of worship are found throughout the New Testament according to Segler:

1. Music had a central place in the Christian's expressions of praise. They sang psalms, hymns, and spiritual songs, making melody in their hearts unto the Lord (Eph 5:18-21; Col 3:16; 1 Cor 14:15; Rev 5:9, 12-13; 12:10-12; 19:1-2, 6).

2. The reading of the Scriptures was definitely an element in early Christian worship (Luke 4:16; Col 4:16; 1 Thess 5:27; 1 Tim 4:13).

3. There is abundant evidence of prayers in the early Christian worship (Acts 2:42; Phil 4:6; Col 2:7; 2 Tim 2:1-2; 2 Cor 13:14; Rev 22:20; Mat 6:9-13).

4. The people's "amens" are seen in numerous places in the New Testament. "Amen" is a term used by the congregation to express approval of what the leader or speaker says (1 Cor 14:16).

5. The sermon or exposition of the Scriptures seems to have been an important part of early Christian worship (see Acts 2:40; 2 Tim 4:1-4).

6. Exhortations was held to be essential in worship (Heb 3:13; 10:24, KJV; 1 Thess 3:2; 2 Thess 3:12; Titus 2:15).

${ }^{1}$ Ibid. 
7. It was customary for Christians to give offerings in public worship (1 Cor 16:2; 2 Cor 9:6-7; 10-13; 2 Cor 8:1-8; Mark 12:42).

8. The doxology is present in the New Testament worship (Eph 1:3).

9. Open confession seems to have been a practice of Christians in the early church (1 Tim 6:12; Rom 10:9; James 5:16).

10. Christian worship included the ordinances of baptism and the Lord's Supper. Jesus commanded His followers to practice the observance of baptism and the Lord's Supper (Matt 28:18-20; Acts 2:38-41; Gal 3:27; Matt 26:26-28; 1 Cor 11:20-34). ${ }^{1}$

Neither Jesus nor Paul laid down a particular order of worship. Perhaps the Model Prayer includes a logical sequence of attitudes in worship, or Paul's insistence upon orderliness and thoughtful discipline in the worship service (1 Cor 14:40).

The absence of an explicit order of the New Testament worship, the clear revelation of three sacraments, and the giving of the principles of dynamic worship all imply a certain freedom and creativity of Christian worship that must be truthful and faithful to God's eternal truth as well as relevant to one's particular context.

\footnotetext{
${ }^{1}$ Segler, 29-31.
} 


\section{CHAPTER III}

\section{ELLEN G. WHITE AND WORSHIP}

When God brought Israel out of Egypt, it was necessary to give them, in addition to the Ten Commandments, a series of laws called casuistic. These laws were intended as a means of education. God was preparing them to be His people to represent Him in this world. Through Israel, God intended to reach other nations.

In the same way, God has brought to existence His last church in this world. The first Adventists came from different religious backgrounds. They had a true and false understanding of Scripture. Therefore, it was necessary for God to give His newborn church additional light in addition to the Scriptures. This additional light has the same purpose as the casuistic laws in ancient Israel.

The additional light that God has given to this church illuminates the principles of the Bible and makes them relevant for God's people today. It is in this additional light which the Lord has given, through His servant, Ellen G. White, that we find instructions regarding the way we should worship Him. As the instructions given by the Lord to Moses about the sanctuary and its service, He, through Ellen G. White, has given us light regarding His church and its worship service. 


\section{Fundamentals of Worship}

We worship God because He invites us to worship. God desires for our daily thoughts to be "withdrawn from the hurry and rush of life," to be aware that there are "unseen witnesses to all we do or say."1 He also desires for us to have fellowship and gladness because of our worship. In fact, Ellen White says that we "do not obtain a hundredth part of the blessing we should obtain from assembling together to worship God."2 We meet together to "edify one another." ${ }^{13}$ The greatest reason for worshipping God is because $\mathrm{He}$ is God, the Creator and we are the created, the creature. ${ }^{4}$

We worship God as Jesus worshiped. He is our example, our pattern:

Christ is our pattern; His life was an example of good works. He was a man of sorrows and acquainted with grief. He wept over Jerusalem because they would not be saved by accepting the redemption which He offered them. They would not come to Him that they might have life. Compare your course of life with that of your Master, who made so great a sacrifice that you might be saved. ${ }^{5}$

Jesus made His teachings interesting by not forgetting the people's human or physical needs. ${ }^{6}$ He did not enforce on the people "long, tedious ceremonies

${ }^{1}$ Ellen G. White, Christ's Object Lessons (Washington, DC: Review and Herald Publishing Association, 1941), 176.

${ }^{2}$ White, Testimonies for the Church, 6:362.

${ }^{3}$ White, Testimonies for the Church, 2:578.

${ }^{4}$ Ellen G. White, The Great Controversy (Mountain View, CA: Pacific Press Publishing Association, 1950), 476.

${ }^{5}$ White, Testimonies for the Church, 1:505.

${ }^{6}$ Ibid., 2:580. 
and prayers." ${ }^{1}$ Jesus' worship was not ostentatious, ${ }^{2}$ and He tried to teach people the real meaning of worship. ${ }^{3}$ As our Guide and Counselor in all our church meetings, ${ }^{4} \mathrm{He}$ will continue to teach us His meaning of worship as we keep Him as our example.

\section{Concerns and Issues}

With the passing of time there has been a growing disregard for the sacredness of the worship of God, the One who created "heaven and earth, and the sea, and the fountains of waters" (Rev 14:7). Ellen G. White makes a valuable statement regarding religious worship in the personal experience of the children of God in these last days:

There has been a great change, not for the better, but for the worse, in the habits and customs of the people in reference to religious worship. The precious, the sacred, things which connect us with God are fast losing their hold upon our minds and hearts, and are being brought down to the level of common things ${ }^{5}$ (emphasis supplied).

${ }^{1}$ Ibid.

${ }^{2}$ White, Desire of Ages, 261.

${ }^{3}$ Ibid., 84, 157.

${ }^{4}$ Ellen G. White, Gospel Workers (Washington, DC: Review and Herald Publishing Association, 1915), 446.

${ }^{5}$ White, Testimonies for the Church, 5:491. 
This is why Mrs. White was concerned about God's children in these last days. She knew that "an enemy has been at work to destroy our faith in the sacredness of Christian worship."1

She had a high concept of the holiness of God, she was very concerned about the sacred things of God. She says that we have reason to be more reverential in our worship that had the Jews. ${ }^{2}$ Therefore she says: "Nothing that is sacred, nothing that pertains to the worship of God, should be treated with carelessness or indifference." ${ }^{13}$

Ellen White says that "the moral taste of the worshipers in God's holy sanctuary must be elevated, refined, sanctified." ${ }^{14}$ Furthermore she states that "because of the irreverence in attitude, dress, and deportment, and lack of a worshipful frame of mind, God has often turned His face away from those assembled for His worship."

Ellen White's concept of worship reflects the life of one who has beheld the awesome glory of God--in her case, many times in life through visions. This is most abundantly reflected in her emphasis on reverence and awe in the worship

${ }^{1}$ Ibid., 496.

${ }^{2}$ Ellen G. White, Child Guidance (Mountain View, CA: Pacific Press Publishing Association, 1974), 541.

${ }^{3}$ White, Testimonies for the Church, 5:491.

${ }^{4}$ Ibid., 5:496.

${ }^{5}$ Ibid., 5:499. 
of God. ${ }^{1}$ God is most real to her in the assembly of worship; He is there. ${ }^{2}$ Hence with great reverential awe, one is urged to "come on bended knee"3 before God, in prayer, ${ }^{4}$ in the preaching of the Word,${ }^{5}$ in the hearing of His truth, ${ }^{6}$ in the service of the sanctuary. ${ }^{7}$ Such a reverential awe can be induced only by awareness and acknowledgement of the "infinite greatness" ${ }^{18}$ of the God who is humanity's "Creator and their rightful Sovereign." ${ }^{19}$ Human beings are to approach God with humility, a contrite spirit, ${ }^{10}$ and gratitude. ${ }^{11}$ In the worship of God, $\mathrm{He}$ is "to be the subject of thought, the object of worship and anything that attracts

${ }^{1}$ There are almost two pages listing reverence in the Comprehensive Index to the Writings of Ellen G. White on reverence. It is true that many of these references are a corrective to the growing irreverence occurring in the churches. However, the counsels must have stemmed from her profound experiences with the holy God through visions and guidance of the Holy Spirit.

${ }^{2}$ White, Prophets and Kings, 48.

${ }^{3}$ Ellen G. White, "Lessons from the Life of Solomon," Advent Review, November 30, 1905, 11.

${ }^{4}$ White, Gospel Workers, 176-78.

${ }^{5}$ Ellen G. White, Evangelism (Washington, DC: Review and Herald Publishing Association, 1946), 210.

${ }^{6}$ White, Testimonies for the Church, 5:493.

${ }^{7}$ Ibid., 5:607-608.

${ }^{8}$ White, Prophets and Kings, 48.

${ }^{9}$ White, Patriarchs and Prophets, 48.

${ }^{10}$ White, Prophets and Kings, 565.

${ }^{11}$ Ellen G. White, "Our Example," Review and Herald, October 24, 1899. 
the mind from the solemn, sacred service is an offense to Him." ${ }^{11}$ The stamp of God's Creatorship is His holy Sabbath which "therefore lies at the very foundation of divine worship." ${ }^{2}$

To the worshippers, "the house of God on earth is the gate to heaven." Christian worship is to be pervaded with the very atmosphere of heaven. ${ }^{4}$ Characteristic of this is orderliness and rules with regard to time, place, and the manner of worship. ${ }^{5}$ Rules and order, however, must never lead to formalism of worship. ${ }^{6}$ Instead, Christian worship must be skillfully studied, planned, and conducted to make it intensely interesting and attractive, ${ }^{7}$ so as to do the greatest amount of good to the worshippers. ${ }^{8}$ Worship is to be made intelligent ${ }^{9}$ so as to impress the worshippers "with the elevated, ennobling character of the truth and

${ }^{1}$ White, Testimonies for the Church, 5:499.

${ }^{2}$ White, Great Controversy, 437-38, citing J. N. Andrews, History of the Sabbath (Battle Creek, MI: Steam Press, 1862).

${ }^{3}$ White, Testimonies for the Church, 5:491.

${ }^{4}$ Ibid., 5: 607.

${ }^{5}$ Ibid., 5:491.

${ }^{6}$ White, Testimonies for the Church, 9:147.

${ }^{7}$ Ellen G. White, Christian Service (Takoma Park, Washington, DC: Home Missionary Department of General Conference of Seventh-day Adventists, 1947), 211-12.

${ }^{8}$ Ellen G. White, "The New Heart," Review and Herald, April 14, 1885.

${ }^{9}$ White, Testimonies for the Church, 2:582. 
its power to cleanse the heart."1 That is, worship should reflect the theology of the three angel's message. Worship calls for active participation "to make the Sabbath meeting interesting."2 Such a worship is truly a communion, a divinehuman dialogue. Ellen White rightly conceives of worship as consisting "much of prayer and praise" and "also preaching. ${ }^{13}$ Such a proper balance, together with congregational singing with understanding and spirit, ${ }^{4}$ thus allows for meaningful participation in worship. Mrs. White's writings well expressed the sovereignty, transcendence, immanence, and mercy of God, and the creatureliness of humanity and its dependence on and gratitude to Him. Thus she calls for an exalted worship of the Creator God with reverential awe, humility, joy and gratitude. She calls for order and rules but also insists on spirituality, intelligence, beauty, and meaning in worship. She calls for great emphasis on the preaching of the Word but also active participation in worship. She calls for a right spirit of worship and also a form and content that should reflect the truth and character of God. The objective reality of God, His awesome greatness as well as the subjective value of congregational participation make worship truly a communion.

\footnotetext{
${ }^{1}$ White, Evangelism, 207.

${ }^{2}$ Ellen G. White, "Love for the Erring," Review and Herald, November 30, 1886.

${ }^{3}$ Ellen G. White, Signs of the Times, June 24, 1886.

${ }^{4}$ White, Testimonies for the Church, 9:143-44.
} 


\section{Principles of Worship in Ellen G. White's Writings}

\section{Reverence}

God is greatly to be feared in the assembly of the saints, and to be had in reverence of all them that are about Him (Ps 89:7 KJV). Ellen G. White had a high concept of the holiness of God, she was very concerned about the reverence in God's house. Therefore she says:

True reverence for God is inspired by a sense of His infinite greatness and a realization of His presence. With this sense of the Unseen the heart of every child should be deeply. The hour and place of prayer and the services of public worship the child should be taught to regard as sacred because God is there. And as reverence is manifested in attitude and demeanor, the feeling that inspires it will be deepened. ${ }^{1}$

Further she mentions the reasons why the children of God should be very careful regarding true worship and true reverence by saying :

Unless correct ideas of true worship and true reverence are impressed upon the people, there will be a growing tendency to place the sacred and eternal on a level with common things, and those professing the truth will be an offense to God and a disgrace to religion. ${ }^{2}$

Thinking of the reverential form and the way of how the heathen worship the idols deities, she says that if we manifest less reverence and awe when we approach the only true and living God, than they toward their idols, "these people will be our judges in the day of final decision." ${ }^{13}$

${ }^{1}$ Ellen G. White, My Life Today (Washington, DC: Review and Herald, 1952), 281.

${ }^{2}$ Ibid., 285.

${ }^{3}$ Ellen G. White, Selected Messages, 2 vols. (Washington, DC: Review and Herald, 1958), 2:314. 


\section{Music}

One of the elements of worship to which Ellen G. White gives emphasis is music. She makes a valuable statement regarding the proper place of music in worship:

The value of song as a means of education should never be lost sight of. Let there be singing in the home, and songs that are sweet and pure, and there will be fewer words of censure and more of cheerfulness and hope and joy. Let there be singing in the school, and the pupils will be drawn closer to God, to their teachers, and to one another.

As a part of religious service, singing is as much an act of worship as is prayer. Indeed, many a song is prayer. If the child is taught to realize this, he will think more of the meaning of the words he sings and will be more susceptible to their power. ${ }^{1}$

In another place Ellen White states that you should "pray more than you sing." ${ }^{2}$ There is a place for music and singing in worship. Yet, it is not often that music is the means of saving people. ${ }^{3}$ Therefore, more people may not come to Jesus because of the over-emphasis on singing and the under-emphasis on praying. There is also the problem of "too much jesting, idle conversation, and gossiping"4 which counters the good which music can bring. The servant of God makes several statements about the character of music in worship. They are both positive and negative. She tells us that the angels "delight to hear the simple

${ }^{1}$ Ellen G. White, Education (Mountain View, CA: Pacific Press Publishing Association, 1952), 168.

${ }^{2}$ White, Testimonies for the Church, 1:513.

${ }^{3}$ Ibid.

${ }^{4}$ Ibid., 4:73. 
songs of praise sung in a natural tone.... They take up the refrain [of the song] that is sung from the heart with spirit and understanding."1

Some think that volume means beauty. This is not true. Very emphatically she declares, "It is not loud singing that is needed." ${ }^{2}$ In the book Evangelism she writes, "Great improvement can be made in singing. Some think that the louder they sing the more music they make; but the noise is not music. Good singing is like the music of the birds--subdued and melodious." ${ }^{13}$

Finally, music can do a lot of good. The problem is that we do not make the most of it.

Singing is generally done from impulse or to meet special cases, and at other times those who sing are left to blunder along, and the music loses its proper effect upon the minds of those present. Music should have beauty, pathos, and power. Let the voices be lifted in songs of praise and devotion. Call to your aid, if practicable, instrument music, and let the glorious harmony ascend to God, an acceptable offering. ${ }^{4}$

This music with beauty, pathos, and power and the ability to sing are both gifts of God. Every gift that God gives can be used for good. It just depends on the individual. Each person needs to develop his/her voice and use it for God's glory. ${ }^{5}$

\footnotetext{
${ }^{1}$ White, Evangelism, 510.

${ }^{2}$ White, Testimonies for the Church, 9:143-4.

${ }^{3}$ White, Evangelism, 510.

${ }^{4}$ White, Testimonies for the Church, 4:71.

${ }^{5}$ Ibid., 9:143-4.
} 
What difference does it make how music is used in worship? As should be expected, there are dangers and benefits. One danger is that one's singing-- or performance of music in general--can be for display, for show, for selfaggrandizement. It is not used to "praise God with the spirit and understanding."1 Another danger is that music can become an idol to the Christian. When that happens--and it may happen more than one is willing to admit--that music which should be a blessing is often used by Satan to trap people. ${ }^{2}$ Expanding on this point she expressed danger that music is one of the "most successful agencies by which Satan allures the mind from duty and from contemplation of eternal things" ${ }^{\prime \prime 3}$ and that with one's "keen ear for music. ... Satan knows what organs to excite to animate, engross, and charm the mind so that Christ is not desired." ${ }^{14}$ "But, rightly employed, it [music and song] is a precious gift of God, designed to uplift the thoughts to high and noble themes, to inspire and elevate the soul." ${ }^{5}$ Music also helps us resist temptation and to be encouraged in times of despair. ${ }^{6}$ As Jesus, in the Sermon on the Mount, brings out the essence of the

\footnotetext{
${ }^{1}$ White, Evangelism, 507.

${ }^{2}$ White, Testimonies for the Church, 1:505-6.

${ }^{3}$ White, Patriarchs and Prophets, 594.

${ }^{4}$ White, Testimonies for the Church, 1:496-7.

${ }^{5}$ White, Education, 167.

${ }^{6}$ Ibid., 168.
} 
law, so Ellen G. White brings out the essence of music. "Music is acceptable to God only when the heart is sanctified and made soft and holy by its facilities."1

Prayer

In order to render acceptable worship the services must be characterized by free prayers. These prayers should come from one who has had private communion with God before the time of public prayer. Those who worship should know that the one who offers the prayer has a living connection with God. ${ }^{2}$ Public prayer from such a person will influence and strengthen the faith of all who are attentive. The mind will be prepared for the preaching of the Word. We must have the continual light that comes from God. Christ is ever sending messages to those who listen to His voice. ${ }^{3}$ "True prayer, offered in the public assembly, at the family altar, or in secret, places man directly in the presence of God." ${ }^{14}$ Ellen G. White states:

Angels record every prayer that is earnest and sincere. We should rather dispense with selfish gratifications than neglect communion with God. The deepest poverty, the greatest self-denial, with His approval, is better than riches, honors, ease, and friendship without it. We must take time to pray. If we allow our minds to be absorbed by worldly interests, the Lord may give us time by removing from us our idols of gold, of houses, or of fertile lands. ${ }^{5}$

${ }^{1}$ White, Evangelism, 512.

${ }^{2}$ White, Testimonies for the Church, 5:8.

${ }^{3}$ White, My Life Today, 15.

${ }^{4}$ Ellen G. White, The Youth Instructor, February 15, 1900.

${ }^{5}$ White, My Life Today, 18. 
Mrs. White has other suggestions for prayer which also should be considered in the setting of the public worship service. "Both in public and private prayer it is our privilege to bow down upon our knees before God when we offer our petition to Him. This act shows our dependence upon Him." ${ }^{11}$ The one giving the prayer should feel it his duty to pray short prayers. "A few minutes is long enough for any public petition." ${ }^{2}$ At another time she wrote that "one or two minutes is long enough for any ordinary prayer. ${ }^{13}$ The prayer should be for a present blessing. It should represent the actual need of all, "expressing their desire for temporal and spiritual blessings and their gratitude for the same." ${ }^{4}$ The one giving the prayer should "speak slowly and distinctly, and in tones loud enough to be heard by all." "Especially should the one offering public prayer use simple language; that the others may understand what is said and unite with the petition." ${ }^{\prime 6}$ No place is left in the service for formal and long prayers. Ellen G. White says that "there should be no long, dry speeches and formal prayers merely for the sake of occupying the time."

\footnotetext{
${ }^{1}$ White, Prophets and Kings, 48.

${ }^{2}$ White, Gospel Workers, 175.

${ }^{3}$ White, Testimonies for the Church, 2:581.

${ }^{4}$ Ibid.

${ }^{5}$ White, Gospel Workers, 89.

${ }^{6}$ Ibid.

${ }^{7}$ White, Testimonies for the Church, 5:609.
} 
Posy, sermonizing prayers are uncalled for and out of place in public. A short prayer offered in fervor and faith, will soften the hearts of the hearers; but during long prayers they wait impatiently, as if wishing that every word might end it. ${ }^{1}$

\section{Preaching}

It is interesting to note the comments by Ellen G. White about the beginning of a sermon. What is a pastor to say in his introduction? Actually she talks more about what he is not to say in the introduction.

Many of you waste time and strength in long preliminaries and excuses as you commence to speak. Instead of apologizing because you are about to address the people, you should commence your labor as though God had something for you to say to them. Some use up nearly half an hour in making apologies; thus the time is flitted away, and when they get to their subject, where they are desirous to fasten the points of truth, the people are wearied out and cannot see their force or be impressed with them. ${ }^{2}$

Again she says "as far as possible, ministers should avoid apologies and preliminaries." ${ }^{13}$

As with prayer in worship, Ellen G. White has a concern about the length of the sermons. She shares part of a vision of June 12,1868 , in which she says that many of the laborers of souls are often preaching one third or one half longer than they need. ${ }^{4}$ She continues with even a stronger statement: "They

${ }^{1}$ White, Gospel Workers, 179.

${ }^{2}$ White, Testimonies for the Church, 2:616.

${ }^{3}$ Ibid., 2: 670.

${ }^{4}$ Ibid., 2:116-7. 
[ministers] should speak short and pray short."1 The reason for this concern is that the hearers will want the speaker to stop. ${ }^{2}$ If there is time left over, it should "be given for those who love God to express their gratitude and adoration."

"Our people should not be made to think that they need to listen to a sermon every Sabbath." ${ }^{14}$ This sounds like a revolutionary statement. Diversity is valuable. Change is helpful. Originality is interesting. Ellen G. White gives a couple of suggestions. One is to model the worship service after a Bible class study. ${ }^{5}$ With the Bible presented in a simple, easily understood way, the congregation would have no problem in understanding the message. Another suggestion is to give time for people to "express their thanksgiving to God." ${ }^{16}$ This allows people to confess Christ and helps them bond to Him. "Make the gospel the glad tidings of salvation to all who receive."7

${ }^{1}$ Ibid., 2:118.

${ }^{2}$ Ibid., 2:117.

${ }^{3}$ Ibid., 6:361.

${ }^{4}$ White, Evangelism, 348.

${ }^{5}$ Ibid.

${ }^{6}$ White, Gospel Workers, 171.

${ }^{7}$ White, Evangelism, 189. 


\title{
Scripture Reading
}

In speaking of the need of studying the Scriptures, Jesus admonished that we should search them (1 John 5:39). To the Christian the Scriptures are the foundation of worship. They are the testimony of Jesus Christ. Ellen G. White wrote that "attention is to be called, not to the assertions of men, but to the Word of God. . . . The Bible is to be opened to all people."1

The Scriptures are to be given a prominent place in the worship services of the church. ${ }^{2}$ They should form the framework of that which is said by the minister. The congregation should also have opportunity to participate in the reading of the Scriptures. In volume 6 of Testimonies for the Church is written:

The Word of the living God is not merely written, but spoken. The Bible is God's voice speaking to us, just as surely as though we could hear it with our ears. If we realized this, with what awe would we open God's word, and with what earnestness would we search its precepts! The reading and contemplation of the Scriptures would be regarded as an audience with the Infinite One. ${ }^{3}$

Ellen G. White counseled that the reading of the Scriptures should be in a clear and distinct voice. "The one who gives Bible reading in the congregation or in the family should be able to read with soft, musical cadence which will charm the hearers." ${ }^{14}$ It is vital for the Christian to "give quiet and devout

\author{
${ }^{1}$ Ibid., 447. \\ ${ }^{2}$ Ibid., 502. \\ ${ }^{3}$ White, Testimonies for the Church, 6:393. \\ ${ }^{4}$ Ibid., 6:380.
}


attention [to the reading of the Bible] as if God were really present and speaking to them."1

\section{Testimonies}

The element of testimonies in the worship service is also vital. Many people are uncomfortable with the testimonies because they think that they have nothing to say. Well they might not! But there is a way to find something to say.

Those who have united with the Lord in the covenant of service are under bonds to unite with Him in the great, grand work of soul saving. Let church members, during the week, act their part faithfully, and on the Sabbath relate their experience. The meeting will then be as meat in due season, bringing to all present new life and fresh vigor. When God's people see the great need of working as Christ worked for the conversion of sinners, the testimonies borne by them in the Sabbath service will be filled with power. With joy they will tell of the precious experience they have gained in working for others. ${ }^{2}$

If we were to work for the Lord during the week, we would have something to say. But even if nothing new happened in a particular week, we could repeat ourselves, which we often feel is inappropriate, and God and the angels are "well pleased and glorified by their [stories] being repeated weekly."

Testimonies are important for every Christian, because

the remnant are to evercome by the blood of the Lamb and the word of their testimony. Some expect to overcome alone by the blood of the Lamb, without making any special effort of their own. I saw that God has been merciful in giving us the power of speech. He has given us a tongue and

${ }^{1}$ Ibid., 5:84.

${ }^{2}$ Ibid., 7:19.

${ }^{3}$ Ellen G. White, Early Writings (Washington, DC: Review and Herald Publishing Association, 1945), 115. 
we are accountable to him for its use. We should glorify God with our mouth, speaking in honor of the truth and of His mercy, and overcome by the word of our testimony through the blood of the Lamb. ${ }^{1}$

${ }^{1}$ Ibid., 114. 


\section{CHAPTER IV}

\section{CONTEMPORARY ISSUES IN WORSHIP}

The first part of this chapter presents the history of the Pentecostal Movement and its powerful influence in mainline churches in the United States, in order to provide a theoretical background to the second part of the chapter which refers to the worship-celebration style in some White Adventist Churches in the North American Division. ${ }^{1}$ In view of the scope of literature, the history seeks only to be representative rather than exhaustive.

The phenomenon of "celebration churches in Adventism" is both drawing a great deal of interest and causing considerable anxiety. What are the key roots of the Celebration Movement? Does it fit into a larger religious frame of reference, namely, the "third wave" of the Charismatic Movement? The answers are considered in the latter part of this chapter.

${ }^{1}$ Adventist Celebration Church in North America is the name given to a Seventh-day Adventist Church that has a different way of worshipping God in an effort to bring a renewal to the traditional patterns of corporate worship. Others say that it is a movement within the Seventh-day Adventist Church to increase and excite members into a "Pentecostal" worship mode. 


\section{History of Pentecostalism in North America}

\section{The Rise of Pentecostalism}

Pentecostalism may be seen as a product of the nineteenth-century American revivals, especially Methodist revivals. ${ }^{1}$

A reading of Linda $K$. Pritchard's, Religious Change in Nineteenthcentury America, would indicate that such revival meetings were part of the Second Great Awakening (1820-60) in American religious history. ${ }^{2}$ It was out of the theology of the founder of Methodism, John Wesley, that the Holiness sects developed in the second half of nineteenth century. ${ }^{3}$

A Methodist convert of this period described a revival meeting as follows:

I have been at meetings where the whole congregation would be bathed in tears and sometimes their cries would be so loud that the preacher's voice would not be heard. Some would be seized with trembling and in a few moments drop to the floor as if they were dead, while others were embracing each other with streaming eyes and all were lost in wonder, love and praise. ${ }^{4}$

${ }^{1}$ Margaret Poloma, The Charismatic Movement: Is This a New Pentecost? (Boston: Twayne Publishers, 1969), 15.

${ }^{2}$ Linda K. Pritchard, "Religious Change in Nineteenth-century America," in The New Religious Consciousness, ed. Charles Y. Glock and Robert N. Bellah (Berkeley: University of California Press, 1976), 297-330.

${ }^{3}$ Poloma, 6 .

${ }^{4}$ Prudencio S. J. Damboriena, Tongues as Fire (Washington, DC: Corpus Publications, 1969), 15. 
During the second half of the nineteenth century the conservative Christian ideology prevailed. The evangelical Protestants, led by theological conservatives, clearly dominated American religion. ${ }^{1}$ According to John D. Woodbridge the fires of Methodist revivalism, which stressed holiness and the experience of a "second blessing," were seen by some to be dimming even before the Civil War by those who felt that "holiness" and "second blessing" were not being taught with enough zeal. ${ }^{2}$ In the years that followed the Civil War, the rise of science influenced some theologians to move away from conservative theology. By the turn of the twentieth century, evangelicals were leading attacks on education and institutions of higher learning with a new intensity. Historian Vinson Synan says that the stage was set for the battle between "modernists," or theological liberals, and "fundamentalists," the upholders of theological conservatism.

William W. Menzies affirms that fundamentalism did not originate from Wesleyan sources as did the Holiness and later Pentecostal sects; it has been viewed as an influence upon the Pentecostal Revival. ${ }^{3}$ George M. Marsden holds

${ }^{1}$ David F. Wells and John D. Woodbridge, The Evangelicals: What They Believe, Who They Are, Where They Are Changing (New York: Abingdon Press, 1975), 13.

${ }^{2}$ John D. Woodbridge, Mark A. Noll, and Nathan O. Hatch, The Gospel in America (Grand Rapids: Zondervan Publishing House, 1979), 73.

${ }^{3}$ William W. Menzies, "The Non-Wesleyan Origins of the Pentecostal Movement," in Aspects of Pentecostal-charismatic Origins, ed. A. Synan (Plainfield, NJ: Logos International, 1975), 84. Leaders of the Church of God may point out that their denomination has Baptist rather than Methodist roots. Despite its denominational background, its theology is Wesleyan. As Church of 
that although not accepted by hard-core fundamentalists to this day, Pentecostal doctrine was more in line with fundamentalism at the turn of the century than with modernism. ${ }^{1}$

The doctrine that separates most Pentecostals from other evangelical Christians is their statement on Spirit baptism. The controversial text reads: "We believe that the full gospel includes the Holiness of heart and life, healing for the body and the baptism in the Holy Spirit with the initial evidence of speaking in other tongues as the Spirit gives utterance." ${ }^{12}$ In order to better understand the significance of the Pentecostal doctrine of Spirit baptism and its relationship to glossolalia, it is important to consider the events that led to the establishment of Pentecostal denominations in the United States of America.

God historian, Charles W. Conn writes: The doctrine of sanctification is distinctly Armenian, and Armenianism rather than Calvinism has produced the greatest revival movement in the nation, particularly in the South. Dr. William Warren Sweet has stated that Calvinist doctrine, with its extreme views of predestination and election, offers salvation to the few, while Armenianism, with its insistence of free will, offers salvation to all. Calvinism is autocratic, while Armenianism is democratic. See Charles W. Conn, Like a Mighty Army (Cleveland: Pathway Press, 1977), 21.

${ }^{1}$ George M. Marsden, "From Fundamentalism to Evangelism: A Historical Analysis," In The Evangelicals, ed. D. F. Wells and J. D. Woodbridge (New York: Abingdon Press, 1975), 124-25.

${ }^{2}$ John Thomas Nichol, Pentecostalism (New York: Harper and Row, 1966), 4. 
The Birth of Modern Pentecostalism

The origin of Pentecostalism in the United States is set at 1901 by some scholars as Watson E. Mills, ${ }^{1}$ Donald W. Dayton, ${ }^{2}$ G. J. Sirks, ${ }^{3}$ Frank J. Ewart, ${ }^{4}$ and Charles G. Hummel. ${ }^{5}$ In 1900, in Topeka, Kansas, Charles Fox Parham, a Holiness evangelist, started Bethel Bible College. He thus established the birthplace of the most startling religious phenomenon of modern time. ${ }^{6}$

Richard Quebedeaux also speaks about the beginning of this movement in Topeka by pointing out that:

Events surrounding the "outpouring of the Spirit" at the school are obscure. According to Parham, he left Topeka for a three-day campaign in Kansas City in late December 1900, and instructed his students to study, in solitude, the baptism in the Spirit, especially as it was recorded in the second chapter of Acts. When he returned, much to his surprise, they all had the same story: and although each account of the Pentecostal blessing was different, "the indisputable proof in each occasion was that they spoke with other tongues. The students and their teacher immediately began to pray and fast, seeking the experience; and on January 1, one of the students, Agnes Ozman, began to speak in tongues after Parham prayed and laid hands on her. Two nights later, the whole company, including Quakers,

${ }^{1}$ Watson E. Mills, Understanding Speaking in Tongues (Grand Rapids: Wm. B. Eerdmans Publishing Co., 1972), 14.

${ }^{2}$ Donald W. Dayton, Theological Roots of Pentecostalism (Grand Rapids: Wm. B. Eerdmans, 1987).

${ }^{3}$ G. J. Sirks, "The Cinderella of Theology: The Doctrine of the Holy Spirit," Harvard Theological Review, April 1957, 50.

${ }^{4}$ Frank J. Ewart, The Phenomenon of Pentecost (Hazelwood, MO: Word Aflame Press, 1947).

${ }^{5}$ Charles G. Hummel, Fire in the Fireplace: Contemporary Charismatic Renewal (Downers Grove, IL: Inter-Varsity Press, 1978).

${ }^{6}$ Ewart, 59. 
Methodists, and Holiness people began to speak in tongues and praise the Lord in a variety of languages. ${ }^{1}$

Less than a week after this Pentecostal outpouring, one of Parham's students, S. J. Riggins, left the company and told the newspapers that the school was a "fake," an account that attracted widespread press coverage. Parham took advantage of this visibility to launch out with his message. But he was singularly unsuccessful and returned to Topeka only to have the school sold out from under his feet. ${ }^{2}$

Robert Mapes Anderson writes that, finally, Parhams was deserted by all except his wife and sister, and things did not improve for him until 1903, when he changed the emphasis of his ministry back to healing. Thus, the movement slowly gained adherents in scattered parts of the Midwest, and in 1905, the evangelist journeyed to Houston, the largest city in Texas. Here he organized yet another school for the training of Christian workers along the same lines as the earlier one in Topeka. ${ }^{3}$

Charles Fox Parham was White, but the leader of Pentecostalism was a Black man, a one-eyed former slave named William Joseph Seymour, who was one of Parham's students in Houston. In his first sermon upon reaching Los Angeles early in 1906 , Seymour boldly proclaimed that no one could be baptized

${ }^{1}$ Richard Quebedeaux, The New Charismatic II (San Francisco, CA: Harper and Row, 1983), 27.

${ }^{2}$ Ibid., 28.

${ }^{3}$ Robert Mapes Anderson, Vision of the Disinherited: The Making of American Pentecostalism (New York: Oxford University Press, 1979), 47-60. 
in the Spirit without speaking in tongues. So Seymour rented a hall in early April at 312 Azusa Street $^{1}$ as a result of his servant.

The historical records suggest that the beginning of the movement depended upon the work and ministry of both men. The distinct Pentecostal pneumatology was formulated under Parham, but it was the implementation of this by Seymour coupled with a fellowship that transcended racial and other barriers, publication of a periodical, and the resulting media attention that made the teaching important. ${ }^{2}$

Douglas J. Nelson points out that emotional displays, especially the glossolalia, attracted a great deal of local attention from both Black and White Holiness camps. ${ }^{3}$ From the Azusa street revival, Pentecostalism spread both in the United States and in Europe. As church historian Vinson Synan observed:

The Azusa Street revival is commonly regarded as the beginning of the modern Pentecostal movement. Although many persons had spoken in tongues in the United States in the years preceding 1906, this meeting brought this belief to the attention of the world and served as a catalyst for the formation of scores of Pentecostal denominations. ${ }^{4}$

${ }^{1}$ Quebedeaux, 29.

${ }^{2}$ Douglas Nelson, "For Such a Time as This" (Ph.D. dissertation, University of Birmingham, 1981), 55.

${ }^{3}$ Ibid., 55-59.

${ }^{4}$ Vinson Synan, The Holiness-Pentecostal Movement (Grand Rapids: Wm. B. Eerdmans Publishing Co., 1971), 114. 


\section{The Rise of Neo-Pentecostalism}

The rise of neo-Pentecostalism or "charismatics"1 appears to have four main sources: (1) the influence of David du Pleiss, (2) the Full Gospel Businessmen's Fellowship International, (3) the Van Nuys, California, awakening, and (4) the Roman Catholic Renewal. ${ }^{2}$ Each of these sources played a major role in bringing Pentecostalism to mainline churches.

1. David du Pleiss, a Pentecostal from South Africa, has done more perhaps than any other individual to reach leaders of established denominations with the charismatic message and has been affectionately nicknamed by many as "Mr. Pentecost."3

David du Pleiss was given a prophecy through the evangelist Smith

Wiggelsworth which du Pleiss reports as follows:

I have been sent by the Lord to tell you what He has shown me this morning. Through the old-line denominations will come a revival that will eclipse anything we have known throughout history. No such things have happened in times past as will happen when this begins. ... It will eclipse the present-day, twentieth-century Pentecostal revival that already is a marvel to the world, with its strong opposition from the established church. But this same blessing will become acceptable to the churches and they will go on with this message and this experience beyond what the Pentecostals have achieved. You will live to see this work grow to such dimensions that the Pentecostal movement itself will be a light thing in

${ }^{1}$ Harold D. Hunter, Spirit-Baptism: A Pentecostal Alternative (Lanham, MD: University Press of America, 1983), 7. See Peter Hocken, "The PentecostalCharismatic Movement as Revival and Renewal," Pneuma 3:1, Spring, 1981, 31-47. Hocken says that the word charismatic is better suited to describe this group.

${ }^{2}$ Poloma, 11.

${ }^{3}$ Robert H. Culpepper, Evaluating the Charismatic Movement (Valley Forge, PA: Judson Press, 1977), 21. 
comparison with what God will do through the old churches. There will be a tremendous gathering of people, unlike anything we've seen, and great leaders will change their attitude and accept not only the message but also the blessing ${ }^{1}$ (emphasis supplied).

Wiggelsworth also prophesied that, du Pleiss was to play a prominent part in this movement. ${ }^{2}$ After that time du Pleiss was led in 1951 to begin sharing the Pentecostal faith and experience in ecumenical circles, particularly within the framework of the World Council of Churches. ${ }^{3} \quad$ David du Pleiss fully expected that they would reject his message; but was amazed at the warm reception they accorded him. ${ }^{4}$ Traveling all over the world as an apostle for Pentecostalism, du Pleiss, was received warmly in meetings large and small of the International Missionary Council, the World Council of Churches, and in churches of all denominations. Moreover, he presented lectures in such prominent seminaries as Princeton Theological Seminary, Yale University Divinity School, Union Theological Seminary in New York City, Southern Methodist University, Colgate Rochester Divinity School, and Fuller Theological Seminary. Pleading with people to stay in their own churches, he counsels, "Be not conformed to

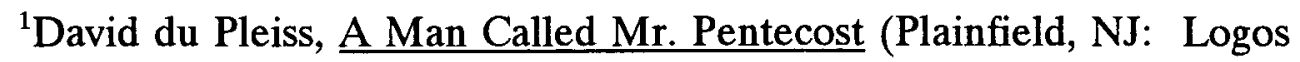
International, 1977), 2.

${ }^{2}$ Ibid.

${ }^{3}$ Culpepper, 21.

${ }^{4}$ David du Pleiss, The Spirit Bade Me Go (Plainfield, NJ: Logos International, 1970), 10-11, 103. See also Michael Harper, As at the Beginning (Plainfield, NJ: Logos International, 1971), 13-20, 51-59. 
Pentecostalism, but be ye transformed by the renewal of your mind in your own church."1

2. The history of neo-Pentecostalism has also been shaped by the role of the Full Gospel Business Men's Fellowship International (FGBMFI), ${ }^{2}$ says historian Margaret Poloma. This fellowship was founded by Californian dairy farmer Demos Shakarian, ${ }^{3}$ with support from the Pentecostal evangelist, Oral Roberts, in $1951 .^{4}$ This lay organization for evangelism and spreading the message of baptism with the Spirit exerted profound influence during the 1960s on the growth of neo-Pentecostalism among both Protestants and Catholics according to Steve Durasoff. ${ }^{5}$ Shakarian's FGBMFI marked a successful outreach of Pentecostals to non-Pentecostals that did not result in a new denomination. FGBMFI may be viewed as a bridge between classical Pentecostals and the neoPentecostal Movement among both Protestants and Catholics, says Margaret Poloma. ${ }^{6}$

${ }^{1}$ David du Pleiss, "The New Pentecost," Logos Journal, March-April, 1974, 2.

${ }^{2}$ Poloma, 13.

${ }^{3}$ Hummel, 43.

${ }^{4}$ Poloma, 13.

${ }^{5}$ Steve Durasoff, Bright Wind of the Spirit: Pentecostalism Today (Englewood Cliffs, NJ: Prentice Hall, 1972), 145.

${ }^{6}$ Poloma, 14. 
Robert H. Culpepper declares that the FGBMFI is constantly carrying on a ministry to millions through its monthly magazine, $\underline{\text { Voice, }}$ its weekly TV program, "Good News," and the ministry of its chapters throughout the world. ${ }^{1}$

3. The Van Nuys, California, Awakening was not until April 3, 1960, when neo-Pentecostalism began to achieve wider recognition. ${ }^{2}$ No single episode in the history of the Charismatic Movement has received more publicity than the events which led to the resignation of Dennis Bennett as rector of the St. Mark's Episcopal Church in Van Nuys, California. He shared his Pentecostal experience (speaking in tongues) with his entire congregation. ${ }^{3}$ Bennett's autobiography, ${ }^{4}$ Nine O'clock in the Morning, tells the story of how Pentecostalism came out of hiding and burst upon the scene on April 3, 1960.

Two days after sharing his experience with his congregation, Bennett sent a letter to his parishioners explaining his conviction;

I'm sorry for the furor, and the pain that has been caused. I ask every person in St. Mark's, whether he be for me or against me, not to leave the Parish or cancel his pledge. This is a spiritual issue, and will not be settled in this way. . . . It is important that the Spirit be allowed to work freely in the Episcopal Church, and it is to this that I bear witness, and will continue to bear witness. I remind you that we are not alone in this. ${ }^{5}$

${ }^{1}$ Culpepper, 23.

${ }^{2}$ Hummel, 45.

${ }^{3}$ Mills, 14 .

${ }^{4}$ Dennis J. Bennett, Nine O'clock in the Morning (Plainfield, NJ: Logos International, 1970).

${ }^{5}$ Trinity, vol. 1, No. 2, 1961-62, 6-7, quoted in Hummel, 45. 
That, of course, was a crucial decision. Shortly thereafter, Bishop Francis Bloy of the Los Angeles Episcopal Diocese banned any more speaking in tongues under church auspices; but later, the remarkable news of the outburst of tongues at St. Mark's was carried in both $\underline{\text { Newsweek }}^{1}$ and Time $^{2}$, and the publicity accorded the event encircled the globe.

R. Quebedeaux says that Dennis Bennett took the Pentecostal experience with him from Van Nuys, California to Seattle, Washington and the number of neo-Pentecostals continued to increase in both areas. ${ }^{3}$ With the dramatic growth of St. Luke's Episcopal Church, Seattle, under the leadership of Bennett, the fame of its pastor spread around the world. Bennett soon became a very popular speaker in the Episcopal Church itself and in other denominations and interdenominational groups where the Pentecostal message was beginning to attract attention.

In 1964, four years after wider reception, neo-Pentecostalism had developed into a recognizable religious movement--affecting both clergy and laity, students and professionals, men and women, in the Episcopal Church and almost all the historic Protestant denominations in the United States. ${ }^{4}$

1"Rector and a Rumpus," Newsweek, July 4, 1960, 77.

${ }^{2 " S p e a k i n g ~ i n ~ T o n g u e s, " ~ T i m e, ~ A u g u s t ~ 15, ~ 1960, ~ 53, ~} 55$.

${ }^{3}$ Quebedeaux, 64.

${ }^{4}$ McCandlish Phillips, "And There Appeared to Them Tongues of Fire," Saturday Evening Post, May 16, 1964, 31-40. 
4. Roman Catholic renewal. A reading of Harold D. Hunter, SpiritBaptism, would indicate that the earliest discernible link in the chain of events which developed into the Roman Catholic Charismatic Movement was the 1967 'charismatic' outbreak at Duquesne University in Pittsburgh, a Catholic University under the direction of the Fathers of the Congregation of the Holy Spirit ${ }^{1}$ (see also the works of Kevin and Dorothy Ranaghan, ${ }^{2}$ Edward D. O'Connor, ${ }^{3}$ Francis A. Sullivan ${ }^{4}$ ). Arthur J. Clement comments that perhaps the greatest surprise in connection with the renewal was its acceptance by many Roman Catholics and the openness with which it was received by members of the hierarchy. ${ }^{5}$

Julia Duin found that Vatican II, the landmark 1962 council, had paved the way for this "new Pentecost" prayed for by Pope John XXIII. ${ }^{6}$ During Vatican II, Belgian Leo Josef Cardinal Suenens successfully argued for more mention of the Holy Spirit and the charismatic gifts in Vatican documents, not guessing that within a decade, he would become Catholicism's highest-profile charismatic.

${ }^{1}$ Hunter, 9.

${ }^{2}$ Kevin Ranaghan and Dorothy Ranaghan, Catholic Pentecostals (New York: Paulist Press, 1969).

${ }^{3}$ Edward D. O'Connor, The Pentecostal Movement in the Catholic Church (Notre Dame, IN: Ave Maria Press, 1971).

${ }^{4}$ Francis A. Sullivan, Charism and Charismatic Renewal (Ann Arbor, MI: Servant Books, 1982).

${ }^{5}$ Arthur J. Clement, Pentecost or Pretense (Milwaukee, WI: Northwestern Publishing House, 1981), 77.

${ }^{6}$ Julia Duin, "Catholics on the Pentecostal Trail," Christianity Today, June 22, 1992, 25. 
For many, old hostilities toward other denominations have all but disappeared via ecumenical, charismatic involvement. One exuberant charismatic who attended the 1977 Charismatic Convention in Kansas City summarized the feeling of many:

Yes, we lifted our hands and swayed and sang, Hallelujah, Our God Reigns. But, more than that, those hands were those of Roman Catholics, Messianic Jews, and Protestants of various groups. We also joined hands, embraced each other, and confessed the hurts we have caused each other in the name of the Lord for so many years. . . There really are no words to describe the Christian love and joy which radiated from the people at the conference. ${ }^{1}$

The Charismatic Movement can be summarized as a penetration of the established churches by the Pentecostal Movement. Charismatic renewal is Pentecostalism. Christians in the renewal now find that they have in common an experience that transcends theological traditions, historical boundaries, and ecclesiastical customs. ${ }^{2}$ Margaret Poloma points out:

As in most contemporary social movements, the charismatic movement is visibly propelled and led by middle-class men and women who, for the most part, are also whites. They have the financial and educational resources to develop an institutional base for the movement. Some middle-class blacks undoubtedly do support aspects of the charismatic movement, but others believe that white Pentecostalism and neo-Pentecostalism have very different ideological and social concerns. ${ }^{3}$

1"Letters to the Editor," Kalamazoo Gazette, 1977.

${ }^{2}$ Clement, 82 .

${ }^{3}$ Poloma, 20, 21. 
A reading of World Christian Encyclopedia, ${ }^{1}$ indicates that in less than a century after its obscure origins in America in 1901, the movement claims a worldwide total of some fifty-one million souls, which--as a group--makes it the largest single element within Protestantism. An additional eleven million members of the Charismatic Movement increase the figure given for practicing Pentecostals to sixty-two million, with as many as one hundred million others under regular influence of Pentecostal teaching. ${ }^{2}$

\section{New Forms of Worship}

\section{Introduction}

The growing emphasis on worship renewal among Seventh-day Adventists is consistent with our belief in the soon return of Jesus. ${ }^{3}$ Worship is very important. It is the main issue in the great controversy between Christ and Satan (Rev 14:7). The final conflict described in prophecy centers on the question of worship. Will we worship the Creator or the beast?

If how we worship is soon to become a test question by which we declare our love, loyalty, and allegiance, then how we are worshipping now is of great importance. Adventists correctly believe and teach that the day of worship is

${ }^{1}$ David B. Barrett, ed., World Christian Encyclopedia, 2 vols. (Oxford: Oxford University Press, 1982).

${ }^{2}$ Richard N. Ostling, "Counting Every Soul on Earth," Time, May 3, 1982, 67.

${ }^{3}$ Clayton Peck, "Does It Matter How We Worship?" Adventist Review, May $28,1992,8$. 
important to God. But both the day and the way we worship are important to God. ${ }^{1}$ In John 4:23 Jesus said: "True worshipers will worship the Father in spirit and truth, for such the Father seeks to worship Him."

Worship is a verb. It is active devotion. The concept of joyful celebration is found throughout the Bible (Exod 10:9; Matt 26:18; Luke 15:24; Rev 4-5; 11:10). The phenomenon of "celebration churches" in Adventism is considered in the following pages of this project report, but regardless of how one views this movement in Adventism, "the real or alleged misuse of a good thing should never cancel its legitimate use."2

\section{The Three Waves of Wagner}

Gerhard F. Hasel points out that as early as 1983 , C. Peter Wagner, professor of church growth at the School of World Mission at Fuller Theological Seminary in California, spoke of the "third wave ${ }^{113}$ of the outpouring of the Holy Spirit. His identification of the three waves of the Holy Spirit's manifestation in the twentieth century has attracted much attention. Dr. Wagner, in a 1983

\section{${ }^{1}$ Ibid.}

${ }^{2}$ Richard Fredericks, "To Celebrate or Not to Celebrate!" Ministry, August $1992,7$.

${ }^{3}$ Gerhard F. Hasel, "The 'Third Wave' Roots of Celebrationism," Adventists Affirm, Fall 1991, 36. 
interview, predicted a new stage or "third wave" of the Holy Spirit's work in this century. ${ }^{1}$

The first wave appeared around 1900 and manifested itself in the traditional Pentecostal churches in which "speaking in tongues" is perceived as the baptism of the Holy Spirit and the key to greater spiritual power. ${ }^{2}$

The second wave showed up in the 1960s when "speaking in tongues" entered most traditional churches of Christianity, including Methodism, Presbyterianism, Lutheranism, the Baptist denominations, the Roman Catholic Church, and several Universities in United States. This wave is also known as neo-Pentecostalism or the Charismatic Renewal Movement. ${ }^{3}$

The third wave developed in the 1980s. It too is part of the Charismatic Movement worldwide. It is characterized, among other things, by an emphasis on so-called power evangelism where the force of prayer is utilized, particularly for the purpose of miraculous healing. A significant part of the current "third wave" of the Charismatic Renewal Movement is the Celebration Church Movement. ${ }^{4}$ Dr. Wagner, referring to this third wave, noted:

We who are neither one of those (first or second wave) would probably never have even heard of the power of the Holy Spirit. So what we are

${ }^{1}$ John Wimber and Kevin Springer, Power Evangelism (San Francisco, CA: Harper and Row, 1986), 122.

${ }^{2}$ Gerhard F. Hasel, Speaking in Tongues (Berrien Springs, MI: Adventist Theological Society Publications, 1991), 9.

${ }^{3}$ Ibid.

${ }^{4}$ Ibid. 
doing is certainly attributable to the way in which God is working in them. What I see is a lowering of traditional barriers between those of us who are evangelicals, and charismatic and pentecostals, so that we can have the same results, the same work of the Holy Spirit in both groups, even though we tend to explain what is happening in a slightly different way. ${ }^{1}$

It is important to recognize that these three "waves" are a part of the Charismatic Movement in Christianity at large. ${ }^{2}$ By means of these "waves" nearly every Christian denomination is being penetrated with the Charismatic Movement in its various shapes and forms. The forces of the Charismatic Movement are immense and often quite adaptable to new settings. ${ }^{3}$

Mission statistician David Barrett estimates (in 1991) that "of the 1.8 billion people who call themselves Christians today, about 372 million identify themselves as Charismatics/Pentecostals. ${ }^{.4}$ Some are tempted to pronounce the charismatic renewal dead because it lacks youthful vitality. True, the early stages of the renewal are over. What we have now is a movement entering late adolescence, if not early adulthood. ${ }^{5}$ In order to understand the "third wave" in its development, we must look at what the charismatic renewal accomplished during its nascent phase.

${ }^{1}$ C. Peter Wagner, "A Third Wave?" Pastoral Renewal, July-August 1983, 15, quoted in Wimber and Springer, 122.

${ }^{2} \mathrm{Hasel}$, Speaking in Tongues, 9.

${ }^{3}$ Ibid.

${ }^{4}$ David Barrett, "Charismatics on Evangelism," Christianity Today, September 16, 1991, 52.

${ }^{5}$ Wimber and Springer, 129. 
According to Wimber and Springer, in most denominations, the charismatic renewal has affected four areas of church life. ${ }^{1}$

First, the charismatic renewal "third wave" has introduced new forms of worship by using dance, theater, innovative hymnody, and (in some instances) singing in tongues. Alive, joyful music is one of the most significant contributions the Charismatic Movement has made to the church.

Second, the charismatic renewal has led the way in renewed social experiences, especially in small groups, innovative discipleship, and Christian community.

Third, the charismatic renewal has stimulated a revival of interest in the ministry of the Holy Spirit. In most mainline denominations, charismatic theology no longer raises the animosity it used to. Being charismatic is no longer controversial.

Fourth, the Charismatic Movement helped renew interest in personal discipline like prayer, Bible study, meditation, and fasting. It is not simply that charismatics can take credit for all the renewed interest in these disciplines, only that they have played a significant part.

So the Charismatic Movement has taken root, burrowing into congregational structures, liturgy, and theology. Inevitably this has changed the renewal's character, not always for the good. Some dangers come with

${ }^{1}$ Ibid. 
acceptance, perhaps the greatest danger being that with respectability easily comes a loss of leavening influence. ${ }^{1}$

The third wave has certain characteristics of doctrine, church practice, and experience. As for doctrine, Wagner points out that "the two principal sources of data [theology and doctrine] are the Bible and the Christian experience."

Charles H. Kraft, professor of anthropology and intercultural communications at Fuller Theological Seminary, declares that the third wave is a movement of the Holy Spirit among Evangelicals. ${ }^{3}$ God is working through faith healers today. ${ }^{4}$ So the new emphasis of the third wave is power prayer, the "filling" with the Holy Spirit. ${ }^{5}$ Wagner affirms that "one can be filled with the Holy Spirit and minister through spiritual gifts in power and be a channel for healing the sick and casting out demons, all without speaking in tongues."

${ }^{1}$ Ibid., 130.

${ }^{2} \mathrm{C}$. Peter Wagner, How to Have a Healing Ministry Without Making Your Church Sick (Ventura, CA: Regal Books, 1988), 16.

${ }^{3}$ Charles H. Craft, Christianity with Power (Ann Arbor, MI: Servant Publications, 1989), xi.

${ }^{4}$ Ibid., 2.

${ }^{5}$ Wagner, How to Have a Healing Ministry, 26.

${ }^{6}$ Ibid. 
The Third Wave and

Adventist Renewal

In an article that appeared in Christianity Today on February 5, 1990,

Kenneth R. Samples states:

And now the third Wave is lapping at Adventism's shores: One Adventist missiologist reports that at least six Adventist congregations have adopted the worship style and kingdom theology of John Wimber's Vineyard Fellowship. This is remarkable in a church that has steadfastly resisted the charismatic renewal, but it shows the adaptability of Adventism ${ }^{1}$ (emphasis supplied).

Early Seventh-day Adventist history

Within Adventist history, I find that some who later became our spiritual forefathers were involved in ecstatic experiences. ${ }^{2}$ These experiences may be noted as: (1) physical prostration; (2) shouting the praises of God; (3) speaking in unknown tongues; and (4) divine healing. ${ }^{3}$ As we look back from our position today, there appears to be convincing evidence that some of these experiences were genuine. There is also evidence that some were counterfeit or were selfinduced in periods of excitement.

Ellen G. White. Ellen White recounts her early experience in the Advent Awakening before the visions were given to her. She reports a number of

${ }^{1}$ Kenneth R. Samples, "The Recent Truth about Seventh-day Adventism," Christianity Today, February 5, 1990, 19, 20.

${ }^{2}$ Arthur L. White, "Tongues in Early Seventh-day Adventist History," Review and Herald, March 5, 1973, 1.

${ }^{3}$ Ibid. 
occasions when she was left prostrate by the overwhelming presence of the Spirit of God. One such experience is believed to have taken place in 1843:

I bowed trembling during the prayers that were offered. After a few had prayed, I lifted up my voice in prayer before I was aware of it. . . I I praised God from the depths of my heart. Everything seemed shut out from me but Jesus and His glory, and I lost consciousness of what was passing around me. The Spirit of God rested upon me with such power that I was unable to go home that night. When I did return, on the following day, a great change had taken place in my mind. It seemed to me that I could hardly be the same person that left my father's house the previous evening. This passage was continually in my thoughts: 'The Lord is my shepherd; I shall not want.' My heart was full of happiness as I softly repeated these words. ${ }^{1}$

In a vision given to her, probably very early in 1845 , and soon after her first vision, which was given in December, 1844, she states: "My strength was taken away, and I fell to the floor. I seemed to be in the presence of the angels." Such experiences were repeated again and again.

Shouting the praises of God. In early 1850, six-month-old James Edson, the second son of James and Ellen White, was very ill. Here is the account as given by James White: "The babe was sick and Ellen anointed and prayed for him. The power came down more and more, and we all shouted and praised the Lord as much as we were a mind to. In this state Ellen was taken off in vision." ${ }^{13}$

${ }^{1}$ White, Testimonies for the Church, 1:31.

${ }^{2}$ Ellen G. White, Life Sketches (Mountain View, CA: Pacific Press Publishing Association, 1915), 71.

${ }^{3}$ James White to Leonard Hastings, January 10, 1850, Ellen G. White Research Center, Andrews University, Berrien Springs, MI. 
Later in the year, at a conference held in Paris, Maine, the believers manifested their rejoicing in loud praises to God. ${ }^{1}$ Ellen White recounts the experience in a letter written November 7 :

Our conference at Topsham was one of deep interest. Twenty-eight were present; all took part in the meeting. Sunday the power of God came down upon us like a mighty rushing wind. All arose upon their feet and praised God with a loud voice; it was something as it was when the foundation of the house of God was laid. The voice of weeping could not be told from the voice of shouting. It was a triumphant time; all were strengthened and refreshed. I never witnessed such a powerful time before. ${ }^{2}$

The records, published and unpublished, in subsequent years indicate that on certain occasions of the special outpouring of the Spirit of God, the saints united in shouts of praise to God.

Speaking in unknown tongues. There are in the church's early history four recorded experiences of speaking in tongues. The first took place in 1847 , apparently to guide a young man to the ministry. The second, in 1848 , involved a doctrinal point. The third, in 1849 , gave guidance to missionary endeavor, and the fourth, in 1851, is a report describing the witness of the Holy Spirit as $\mathrm{He}$ manifested the "presence and power of God."3

1Arthur White, "Tongues in Early Seventh-day Adventist History," 5.

${ }^{2}$ Ellen G. White to the church in Brother Hasting's house, November 7, 1850, Letter 28. (Manuscripts and letters of E. G. White cited in this project report are all located in the Ellen G. White Research Center, Andrews University, Berrien Springs, Michigan.)

${ }^{3}$ Arthur White, "Tongues in Early Seventh-day Adventist History," 5. 
Herald through a letter written to James White by Sister F. M. Shimper. She speaks of the deep experience of the church at East Bethel. Vermont. and reports that the Lord had recently sent

and abundantly blessed the labors of His servant, Brother Holt, among us. After baptizing six of our number, our dear brother Morse was set apart by the laying of hands, to the administration of the ordinances of God's house. The Holy Ghost witnessed by the gift of tongues, and solemn manifestations of the presence and power of God. The place was awful, yet glorious. We truly felt that 'we never saw it on this fashion."

Ecstatic experiences. ${ }^{2}$ In December, 1850. took place the first ecstatic experience, while at Paris, Maine, attending a conference where all present sensed the deep need of the outpouring of the Spirit of God, Ellen White was given a vision. The significance of this vision cannot be overrated. It is a key document. The believers were praying for an outpouring of the Holy Spirit, possibly hoping for some physical observed demonstration. The records of the time show an acceleration in ecstatic experience. ${ }^{3}$

In the vision she was shown that in the ecstatic experiences there was grave danger of adulteration, the former opinion of the individual involved governing, in a measure the exercise. This being the case, implicit confidence could not be placed in such experiences. ${ }^{4}$ She was shown the possible negative

${ }^{1}$ F. M. Shimper to James White, Review and Herald, August 19, 1851, 15.

${ }^{2}$ Ecstatic experience: An overpowering feeling of joy or delight; state of rapture.

${ }^{3}$ Arthur L. White, "Bible Study Vs. Ecstatic Experiences," Review and Herald, March 22, 1973, 7.

${ }^{4}$ Ibid. 
governing, in a measure the exercise. This being the case, implicit confidence could not be placed in such experiences. ${ }^{1}$ She was shown the possible negative effects of "unnecessary" excitement and that there was a grave danger of disregarding the Word of God and "trusting in exercises." She was shown that there were genuine experiences in which there were charismatic exercises, but that there was danger ahead. ${ }^{2}$

There is no record of Ellen White's giving explicit support to, or placing her endorsement upon, these ecstatic experiences with unknown tongues, although she was an eyewitness to three of the four. ${ }^{3}$ In addition to dependence upon feelings and in experiences such as unknown tongues, there was danger of false guidance. In this respect she wrote: "I saw that Satan was working through agents in a number of ways. He was at work through ministers who have rejected the truth and are given over to strong delusions to believe a lie that they might be damned." ${ }^{14}$

In later years Mrs. White warned about counterfeit ecstatic experiences:

Whenever and wherever the Lord works in giving a genuine blessing, a counterfeit is also revealed, in order to make of no effect the true work of God. Therefore we need to be exceedingly careful, and walk humbly before God, that we may have spiritual eyesalve that we may distinguish the working of the Holy Spirit of God from the working of that spirit that would bring in wild license and fanaticism. 'By their fruits ye shall know

${ }^{1}$ Ibid.

${ }^{2}$ Ibid.

${ }^{3}$ Ibid., 8.

${ }^{4}$ White, Early Writings, 43, 44. 
them' (Matt 7:20). Those who are really beholding Christ will be change into His image, even by the Spirit of the Lord, and will grow up to the full stature of men and women in Christ Jesus. The Holy Spirit of God will inspire men with love and purity; and refinement will be manifest in their characters. ${ }^{1}$

The second experience involving spurious ecstatic exercises took place in central Wisconsin in 1860 and 1861. Involved were T. M. Steward and his wife (early believers in that state, who had come to some position of leadership) and a certain Salomon Wellcome family. ${ }^{2}$ The Stewards, who required some time to make a full recovery, eventually again became trusted workers. Their daughter Mary served many years as a proofreader in the Review and Herald and for several years as one of Mrs. White's secretaries. ${ }^{3}$

The third experience of the involving ecstatic exercises and one that Ellen White comments on at considerable length took place in Portland, Maine, in the years 1864 and $1865 .^{4}$ With the firm counsel given by Mrs. White, based on the vision God gave her, the fanatical element among Sabbath keepers in Portland, Maine, was soon quenched. It is little wonder that as she came face to face with

${ }^{1}$ White, Selected Messages, 1:142.

${ }^{2}$ Arthur L. White, "Face to Face with the Spurious," Review and Herald, March 29, 1973, 10.

${ }^{3}$ Ibid., 11.

${ }^{4}$ White, Testimonies for the Church, 1:412-14, 418, 419. 
ecstatic experiences, in the years to follow she would approach them guardedly, cautiously, probing to discern the true elements involved. ${ }^{1}$

This she did in the experience in 1908 as Mr. and Mrs. Ralph Mackin called on her to learn whether their experience of talking in tongues and singing in the spirit was divinely leading. It was in this connection that Ralph Mackin pressed Ellen White for an answer to the question of the propriety of looking for and expecting some physical demonstration in connection with the work of the outpouring of the Spirit of God. ${ }^{2}$ I quote Mackin's question and statement and Ellen White's reply.

R. Mackin: In connection with the receiving of power from on high there is a question, it seems to me, just as pertinent now as in the days of the apostles--What is the evidence? If we receive it, will it not have the same physiological effect on us as it did back there? It can be expected that we shall speak as the Spirit gives us utterance.

Ellen White: In the future we shall have special tokens of the influence of the Spirit of God--especially at times when our enemies are the strongest against us. The time will come when we shall see some strange things; but just in what way--whether similar to some of the experiences of the disciples after they received the Holy Spirit following the ascension of Christ--I cannot say. ${ }^{3}$

Shortly after this she was shown in vision that the Mackin experience was spurious. It was not the Spirit of the Lord that was inspiring the Mackins.

${ }^{1}$ Arthur L. White, "The Gift of Tongues at Portland, Maine," Review and Herald, April 5, 1973, 7.

${ }^{2}$ Ibid.

${ }^{3}$ Arthur L. White, "The Word--Not Feeling," Review and Herald, August $17,1972,4$. 
It is interesting to observe that Ellen White, with the many, many visions given her down through the years, felt unable to declare unequivocally that there would be an ecstatic experience, such as speaking in unknown tongues, in connection with the outpouring of the Spirit of God. In fact, at no time did she link the evidences of the outpouring of the Spirit--sometimes spoken of as the baptism of the Holy Spirit--with ecstatic experiences. She taught that the experience of Pentecost enabled the disciples to speak fluently in known languages. This was true also of the experience at Ephesus recorded in Acts 19:6. Early Adventist sources frequently referred to healing miracles. Incidents in the church today indicate that the gift of healing is still with us. ${ }^{1}$ For example Mrs. White reported the miraculous healing of Frances, the daughter of Stockbridge Howland in $1840,{ }^{2}$ and of William Hyde, who was gravely ill with dysentery. ${ }^{3}$ In 1848 Ellen White recounted the healing of Sister Penfield, right after the first of the Sabbath conferences in Rocky Hill, Connecticut. ${ }^{4}$

These particular examples (there are many more) illustrate the close link that early believers saw between physical healing and the outpouring of the Holy Spirit. "Oh, how grateful we should be that Jesus is willing and able to bear all ${ }^{1}$ Arthur L. White, "Miraculous Healing," Review and Herald, April 12, 1973, 4.

${ }^{2}$ White, Life Sketches, 74.

${ }^{3}$ Ibid., 76.

${ }^{4}$ Ellen G. White, Letter 1, 1848, quoted in Arthur L. White, "Miraculous Healing," 5. 
our infirmities and strengthen and heal all our diseases if it will be for our good and for His glory."1 And in her book, Ministry of Healing, ${ }^{2}$ she devotes an entire chapter to "Prayer for the Sick."

God is just as willing to restore the sick to health now as when the Holy Spirit spoke these words through the psalmist. And Christ is the same compassionate physician now that $\mathrm{He}$ was during His earthly ministry. In Him there is healing balm for every disease, restoring power for every infirmity. ${ }^{3}$

However, Ellen White warned of counterfeit healing miracles that the children of God are going to experience in the last days:

If we accept not the truth and love it, we may be among the number who will see the miracles wrought by Satan in these last days, and believe them. Many strange things will appear as wonderful miracles, which should be regarded as deceptions manufactured by the father of lies. . . . Men under the influence of evil spirits will work miracles. They will make people sick by casting their spell upon them, and will then remove the spell, leading others to say that those who were sick have been miraculously healed. This Satan has done again and again. ${ }^{4}$

We are warned that in the last days Satan will work with signs and lying wonders. He will continue these wonders until the close of probation, that he may point to them as evidence that he is an angel of light and not of darkness. ${ }^{5}$

${ }^{1}$ Ellen G. White, Medical Ministry (Mountain View, CA: Pacific Press Publishing Association, 1932), 16, 17.

${ }^{2}$ Ellen G. White, The Ministry of Healing (Mountain View, CA: Pacific Press Publishing Association, 1942), 225-233.

${ }^{3}$ Ibid., 26.

${ }^{4}$ White, Selected Messages, 2:48, 49.

${ }^{5}$ Ibid., 50, 51. 
Through the seventy years of her ministry to the Adventist Church and the world, Ellen G. White was closely tied into the work of the Holy Spirit--so closely that the Spirit gave her 2,000 visions. ${ }^{1}$ She repeatedly spoke of being abundantly imbued by the Spirit, but there is no record of her ever speaking in an unknown tongue, or in any tongue but English. ${ }^{2}$ At the same time, through the years Mrs. White made scores of references to the need of the Holy Spirit, the baptism of the Holy Spirit, and experiences in which the Spirit was poured out.

The Comprehensive Index to the Writings of Ellen G. White ${ }^{3}$ carries thirty-one specific references to baptism of the Holy Spirit. In not one instance does she link the ecstatic speaking in tongues with the baptism of the Spirit, either historically or prophetically. ${ }^{4}$ She does not make one reference to ecstatic experiences as a sign that God has favored His people with His Spirit. ${ }^{5}$ Evidence of the true baptism of the Spirit, she said often, would manifest itself in increased unity among believers and in new motivation and empowerment to spread the gospel message. Referring to the time of the latter rain she said:

The Spirit and power of God will be poured out upon his children. At that time many will separate themselves from those churches in which the love

${ }^{1}$ Arthur L. White, "Ellen G. White and the Baptism of the Holy Spirit," Review and Herald, April 19, 1973, 8.

${ }^{2}$ Ibid.

${ }^{3}$ Comprehensive Index to the Writings of Ellen G. White, 3 vols. (Mountain View, CA: Pacific Press Publishing Association, 1962).

${ }^{4}$ Arthur L. White, "Ellen G. White and the Baptism of the Holy Spirit," 8. ${ }^{5}$ Ibid. 
of this world has supplanted love for God and His Word. Many, both of minister and people, will gladly accept those great truths which God has caused to be proclaimed at this time to prepare a people for the Lord's second coming. ${ }^{1}$

Then, in prophetic words, she describes how the enemy will intrude, introducing a counterfeit to deceive us.

The enemy of souls desires to hinder this work; and before the time for such a movement shall come, he will endeavor to prevent it by introducing a counterfeit. In those churches which he can bring under his deceptive power he will make it appear that God's special blessing is poured out; there will be manifest what is thought to be great religious interest. Multitudes will exult that God is working marvelously for them, when the work is that of another spirit. ${ }^{2}$

How careful we must be to guard against being swept off our feet in the modern ecumenical movement that claims to bind together all men everywhere under the banner of love. ${ }^{3}$ There exists in these last days evils similar to those that threatened the prosperity of the early church. ${ }^{4}$ "In many of the revivals which have occurred during the last half century, the same influences have been at work, to a greater or less degree, that will be manifest in the more extensive movements of the future.." Ellen G. White pointed out that:

${ }^{1}$ White, The Great Controversy, 464.

${ }^{2}$ Ibid.

${ }^{3}$ Arthur L. White, "God-Given Criteria," Review and Herald, April 26, $1973,8$.

${ }^{4}$ Ellen G. White, Acts of the Apostles (Mountain View, CA: Pacific Press Publishing Association, 1911), 554.

${ }^{5}$ White, The Great Controversy, 464. 
There is an emotional excitement, a mingling of the true with the false, that is well adapted to mislead. Yet none need to be deceived. In the light of God's word it is not difficult to determine the nature of these movements. Wherever men neglect the testimony of the Bible, turning away from those plain soul-testing truths which require self-denial and renunciation of the world, there we may be sure that God's blessing is not bestowed. And by the rule which Christ Himself has given ${ }^{1}$ (emphasis supplied).

What we are called upon to do will not be easy or make us popular. We must refrain from judging in the wrong sense; we must ever reach out to others with love in our hearts; but our security comes only in keeping before us the criteria that God has established. $^{2}$

After looking back, from our position today, to some aspects in the experience of the early Adventists relating to the worship of God the Creator and the manifestations of His power in His church, I will now consider the so-called phenomenon of "celebration churches" in Adventism on the eve of the twentieth century.

\section{Beginning of Celebration}

Churches in Adventism

The oldest celebration church is the New Life Celebration Church of Seventh-day Adventist, in Milwaukee, Oregon, whose Sabbath morning attendance has risen from 140 in 1982 to more than 1,200. The largest is now the Celebration Center of Seventh-day Adventists, in Colton, California, which was

${ }^{1}$ Ibid.

${ }^{2}$ Arthur L. White, "God-Given Criteria," 8. 
spawned in 1989 from the nearby Azure Hills Seventh-day Adventist Church and whose attendance now reaches 1,500 on Sabbath morning. ${ }^{1}$

Rarely has the Seventh-day Adventist Church in North America been challenged to rethink its historical patterns of worship as much as it has been in recent years. With the birth and rapid growth of several large "celebration-style" Adventist churches and with hundreds of congregations adding celebrative elements to their worship service, the church has been, and is being, forced to restudy the entire concept of worship and to see how much innovation it will allow. ${ }^{2}$

While the "celebration churches" now number less than a dozen of the nearly 4,500 Adventist churches in North America, they have captured the national attention of the church because of their lively, participatory worship services, and because they have been highly successful in attracting large numbers of people--particularly former and inactive members--to Sabbath morning worship services. ${ }^{3}$

What is a celebration church? Defining what an Adventist celebration church is all about is a difficult task at best, says Widmer, simply because there is no one celebration church, or one pattern. Celebration churches vary from the 180-member church near Buffalo, New York, to the large Celebration Center in

${ }^{1}$ Myron Widmer, "Adventist Worship--Celebration-Style," Adventist Review, November 1, 1990, 13.

${ }^{2}$ Ibid., 12.

${ }^{3}$ Ibid. 
Colton, California. Each is distinctly different, though each has adopted the "celebration" label. Others give the following definition: "A movement within the Seventh-day Adventist Church to increase and excite members into a 'Pentecostal' worship mode."1

Without a generic example, perhaps the best we can do is to summarize the characteristics common to the Milwaukee and Colton congregations, two large and successful celebration churches.

1. Both have pastors with a vision to change: Dave Snyder of Milwaukee and Dan Simpson of Colton dreamed of a different experience for their congregations--of a spiritual healing community, where warm Christian fellowship would permeate every aspect of church life, where former members could return and feel safe.

2. Both have a celebrative worship service: Undoubtedly this is the most heralded feature--the centerpiece--of celebration churches. It is a time of praise, of music, of prayer, of preaching, of fellowship. Members come to celebrate their joy in the Lord. The celebration begins on the parking lot with greeters who welcome everyone, and before people get inside the front door someone else welcomes them. Worship always begins with lively, joyful singing for about fifteen to thirty minutes. Praise songs predominate, most of which give praise to God and are not just about Him. Clapping is not discouraged. Each church has created what it calls the Garden of Prayer or the Altar of Prayer, where the

\footnotetext{
${ }^{1}$ Kenny Shelton, "What's Wrong with Celebration?" (West Frankfort, IL: By the author), 4 .
} 
pastor invites people to come fonward and kneel for what would be considered a pastoral prayer, lay pastors move quietly from person to person, momentarily laying hands on the shoulders of those kneeling--simply as a sign of caring for one another. Sermons are almost always given by the senior pastor without the aid of a formal pulpit. Sermon time is guarded carefully, lasting the usual half hour or more.

Snyder plans the Milwaukee worship service to be unpredictable, adding an air of expectancy to the experience. The same expectancy is nurtured at Colton through dramatized readings with participants acting out unrehearsed scenes for the children's story time (Celebration Center employs a half-time drama stage director) dialogues, and such innovations as Bring Your Brother Day. Services at both churches last up to one and a half hours (with no one leaving early!).

3. Both exhibit love, acceptance, and forgiveness: Another common characteristic is that their pastor's sermons usually stress the themes of love, acceptance, and forgiveness--the biblical themes upon which these celebration churches seem to center their theology.

4. Both have fellowship groups: Growth opportunities abound, and sense of openness prevails. Whatever the individual problem, the church wants to be of help finding healing in a restored relationship with God.

Each church nurtures an array of small group ministries, a variety of Sabbath school classes and options (from traditional classes to seminars on various 
spiritual topics), reformatted "prayer" meetings during the week, singles' ministries, divorce recovery ministry, age--specific groups--youth, "20 something," and other--Bible Fellowship, and social activities.

5. Both focus on reclaiming former members: Each church places a high priority on reaching out to former and missing Seventh-day Adventists within its ministry area.

So far, the Milwaukee New Life Celebration Church has reclaimed more than 300 former Adventists in the past eight years. And the Colton Celebration Center has attracted hundreds of former and inactive Adventists. ${ }^{1}$

After considering these characteristics common to the two largest and oldest celebration churches, the report will concentrates on the positive and negative reactions toward "celebration churches" in Adventism.

\section{Reaction toward the "Celebration}

Churches" in Adventism

A few years ago, hardly anyone knew what a "celebration church" was. Today, that picture has changed. Mention the word "celebration" among a group of Adventists, and one is almost guaranteed of generating an enthusiastic discussion.

Dr. William H. Shea says that the celebration church concept brings up the age-old tension between two distinctly different views of the person and

\footnotetext{
${ }^{1}$ Widmer, 13, 14.
} 
presence of God. ${ }^{1}$ One view stresses the highness and holiness of the great creator God who dwells in heaven and from there guides all His activities in the world. The other emphasizes God's presence and oneness with His people in the world. $^{2}$

We have to remember that one of the characteristics of the Seventh-day Adventist Church is that, throughout the world, it has almost the same pattern of worship. There are some cultural differences, but this is more in enthusiasm than in the form of worship. For instance, we can see a difference between a Seventhday Adventist American White church and a Spanish church or a Black church. This difference in worship has nothing to do with the spiritual situation of these churches, but rather, it is a matter of cultural background.

Nonetheless, the Seventh-day Adventist Church standard of worship, in North America, has been challenged since the 1980 s by the so-called "CelebrationStyle Worship." These innovations in several Adventist congregations have raised the question of whether celebration in worship is a neo-Pentecostal threat. Some even consider it dangerous to use the word "celebration" in describing any component of the worship service. ${ }^{3}$

Such reaction is a bit surprising since most members have never set foot inside a celebration church. But they have formed strong opinions for or against--

${ }^{1}$ William H. Shea, "God: Transcendent or Immanent?" Adventist Review, November 1, 1990, 14.

${ }^{2}$ Ibid.

${ }^{3}$ Fredericks, 7 . 
attacking or staunchly defending the latest innovation in Adventist ministry among Anglo congregations. ${ }^{1}$

\section{Critics of the "Celebration Movement"}

Some critics charge that the celebration churches have simply adopted traditional Pentecostalism, where emotions run high and solid biblical content and truth are lacking. Others suggest that these churches, in their desire to attract young people and former members, have turned their worship services into entertainment and have forsaken traditional Adventist standards. ${ }^{2}$

Still others categorically assert that this is "no time to celebrate." Instead, our lives and our worship should be marked by weeping and sighing. Celebration, they say, must wait until the coming of Christ. One article through an exegesis of Isaiah 22 concludes that celebration worship is the unpardonable sin in the last days. ${ }^{3}$ The celebration church is a false revival because celebration may appear to have "revival" in the midst but it does not have reformation. ${ }^{4}$

Surely one can see that the roots of the celebration format are "not only charismatic, but the One-World Church is obviously bound together by the

${ }^{1}$ Widmer, 12.

${ }^{2}$ Ibid.

${ }^{3}$ Marshall Grosboll, "No Time to Celebrate," Our Firm Foundation, December 1990, 15.

${ }^{4}$ Shelton, 5 . 
charismatic."1 Mega-ministry is sweeping through the churches and the Adventist celebration church is running with it. ${ }^{2}$

Commenting on Mega-ministry, a Newsweek article says:

Unlike earlier religious revivals, the aim this time (aside from born-again traditionalists of all faiths) is support not salvation, help rather than holiness, a circle of spiritual equals rather than an authoritative church or guide. A group affirmation of self is at the top of the agenda, which is why some of the least demanding churches are now in greatest demand. ${ }^{3}$

"It seems to me that the demonstrative Celebration type of worship service is attempting to produce the end result of a genuine salvation experience by using quick-serve, artificial methods," wrote Joe Crews in $1992 .{ }^{4}$

Are the celebration churches the right solution for much of the malaise in first-world Adventism? What "sources" are celebration churches drinking from? What "fire" are they playing with? What spirit is at work? Where else does the movement lead?

\section{Supporters of "Celebration Churches"}

Something beautiful could be lost if we take the critics' voices seriously.

We need celebration. The true gospel requires it. It is crucial to the corporate

${ }^{1}$ Ron Thompson, "The Celebration Approach to Worship," Our Firm Foundation, July 1991, 21.

${ }^{2}$ Ibid., 23.

${ }^{3}$ Kenneth L. Woodward and others, "A Time to Seek," Newsweek, December 17, 1990, 56.

${ }^{4}$ Joe Crews, "Insights into the Celebration Church," Pilgrim's Rest (Beersheba Springs, TN: By the author, 1992). 
life and evangelistic outreach of the Adventist Church. It is central to Christcentered worship. It is vital to the health of Christians as individuals. Without it, our souls shrivel. ${ }^{1}$

Those who are praising the celebration worship, former and inactive Seventh-day Adventist members, talk about the great spiritual blessing that they have received by participating in this worship. Still others commend the new celebration churches for making Christianity personal, vibrant, and inviting. ${ }^{2}$ They enthusiastically praise the celebrative worship services that are alive with music and expressions of one's happiness in the Lord.

Celebration is a grand word. God forbid we should impart to it a meaning quite apart from accepted usage. ${ }^{3}$ When we recognize that celebration has more to do with remembering, praising, and extolling than with frivolity or confusion, we place it in its correct perspective. ${ }^{4}$

Heaven's worship as pictured in Rev 4 and 5 is certainly celebration," wrote Dr. C. Raymond Holmes in 1984. "When the church gathers in the

${ }^{1}$ Fredericks, 7.

${ }^{2}$ Widmer, 12 .

${ }^{3}$ Eoin Giller, "Worship Renewal in the Seventh-day Adventist Church," Ministry, October, 1991, 18.

${ }^{4}$ Ibid.

${ }^{5}$ C. Raymond Holmes, Sing a New Song (Berrien Springs, MI: Andrews University Press, 1984), 21. 
presence of its Lord, its worship too should be a celebration. ... Celebrating the presence of God is the central characteristic of all Christian worship."1

Perhaps we should be grateful that celebration worship is calling attention to the long overdue need for worship renewal in our churches. Not giving worship the attention Rev 14:6, 7 demands has created a vacuum. Perhaps God is giving the Seventh-day Adventist Church an opportunity to respond more fully to the first angel's message, and to begin to think seriously about an Adventist theology of worship. ${ }^{2}$

God does not want our hearts to race ahead of our heads; neither does

He want us to deny our emotions. "There is nothing wrong with opening our hearts to express fervent public praise for Jesus, as long as we don't use celebration as a substitute for keeping the commandments. ${ }^{13}$

"I've noticed that some Adventists who oppose celebration worship have no objection to celebrating secular things, like ball games. . . That's supposed to be OK. But you had better sit stone still in church while heaven rejoices over sinners responding to an altar call. ... Stop celebrating Jesus Christ? Impossible! If the Adventist Church won't celebrate, the stones around us will cry out." ${ }^{14}$

We ought to thank God, says Weber, for the trend toward celebration in the Seventh-day Adventist Church--although I do not think we can automatically put a seal of approval on everything that makes for happy worship. We must be

${ }^{1}$ Ibid.

${ }^{2}$ C. Raymond Holmes, "Authentic Adventist Worship," Ministry, October 1991, 15.

${ }^{3}$ Martin Weber, Adventist Hot Potatoes (Boise, ID: Pacific Press Publishing Association, 1991), 13.

${ }^{4}$ Ibid., 14, 15. 
aware of the temptation to condemn those whose worship style differs from our own. We do not all have to adore God the same way. For one thing, we have different personalities. Some are quite emotional about their salvation, while others who equally appreciate Calvary are peacefully reflective. ${ }^{1}$

\section{Conclusion}

Regardless of how one views the "celebration movement" in Adventism, the real or alleged misuse of a good thing should never cancel its legitimate use. Though greedy hucksters constantly misuse the Bible, we continue to study it. Even though society constantly abuses money and sex, God does not call us to become celibate paupers. Therefore, with the biblical concept that worship is a communal celebration of life in Christ, we should not reject it even though some might abuse it. ${ }^{2}$

Celebration worship may be nothing more than a liturgical comet, dazzling on the way to a fade-out, leaving only a memory. Still, serious questions arise concerning this phenomenon flashing across the Adventist sky. (1) Where will it ultimately lead us? (2) To what extent is it a form of neoPentecostalism? (3) How far afield are we willing to look for inspiration today? (4) Can inspiration no longer be found in the message and mission of the Seventh-day Adventist Church? (5) Is the real problem with the theology that supports celebration worship and informs the preaching that takes place in that context? ${ }^{3}$

The celebration worship style has its strengths and weaknesses. Its strength is in its mission. The celebration worship leaders know their goal and

\footnotetext{
${ }^{1}$ Ibid., 19.

${ }^{2}$ Fredericks, 7 .

${ }^{3}$ Holmes, "Authentic Adventist Worship," 15.
} 
are having success. They know their target and they are hitting it. And yes, our church needs to emphasize and practice love, forgiveness, and acceptance. But where I disagree with this worship style is in the area of combining worship and fellowship in the sanctuary, and with the music and how it is used. The music has the power to influence the feelings; it is a powerful instrument in Satan's hands. I do not agree with their concept of reverence.

It is not my conclusion that the celebration worship style is wrong. Nevertheless, by my research, I have learned that this worship style had its genesis in the charismatic Pentecostal worship style which exhibits the same pattern: a high content of music and an emphasis on love, forgiveness, and acceptance. The charismatic worship is designed to attract people, therefore the Christian ethic is not emphasized.

This subject is not as clear-cut as some portray it. The Bible and Ellen G. White speak to both sides of the issue--to dull, boring services, and to worship that becomes entertainment. Most White churches in the North need innovation in their ministries. But in their push for innovation, they need to remember that new is not automatically better, neither is old always effective.

I conclude this chapter sharing how Ellen G. White underscores in a very emphatic way the eschatological hope in the hour of Christian worship: "To the humble, believing soul, the house of God on earth is the gate of heaven. The song of praise, the prayer, the words spoken by Christ's representatives, are God's 
appointed agencies to prepare a people for the church above, for that loftier worship into which there can enter nothing that defileth."1

In our spiritual hunger, in our longing for revival and power from on high, let us seek our direction from God's Word. In Scripture we will find renewed strength and divine power to discover and rediscover the will of God for His people in the end-time. Adventists are a people of the Book; and the Spirit who speaks through that Book will renew us.

${ }^{1}$ White, Testimonies for the Church, 5:491. 


\section{CHAPTER V}

\section{DEVELOPMENT OF A BASIC OUTLINE}

My own experience is similar to that of a large number of people in the Seventh-day Adventist Church today who were not prepared to take their place in the worship life of an Adventist congregation in a meaningful and understanding way. This is why it is urgent to have a clear understanding of Seventh-day Adventist worship.

It is incongruous that the church which recognizes the centrality of worship in the Great Controversy, doctrinally, gives it such little attention in membership preparation. Based on my own experience and on what I can see in the country where I am presently serving, my goals in developing a course in Seventh-day Adventist worship for pastoral students at Montemorelos University are to prepare pastors for worship planning, leadership and renewal in the Seventh-day Adventist Church.

\section{Goals}

Three are the goals the researcher is planning to reach in this class.

1. Worship planning: To help the students recognize the importance of 
planning worship and to give them ideas to avoid dullness and routine in this heaven-directed activity.

Such a way of planning for the entire service, and for the various parts, calls for the use of imagination, which is the synthesizing power. The minister who has this power and uses it aright in planning for public worship is an artist.

2. Leadership in worship: To demonstrate that the minister, by virtue of his calling, is the key person in the service of worship.

The minister should incarnate the spirit of worship. When the Holy Spirit falls upon the minister and his service, the desired results will be assured.

3. Worship renewal: The student should know about the need we have in the area of worship renewal, improvement and growth respecting worship and liturgy in the Seventh-day Adventist Church.

\section{Pedagogical Methodology}

The pedagogical methodology that will be used in the course consists of:

1. Lecture: The teacher will share information with the class regarding the topic at hand. The student should take notes which will be used for the examinations and also for discussions. The participation of each student in class is very important because the students come from different parts of the Republic and have had different experiences related with corporal worship.

2. Group dynamics: Practical questions will be given to the students for discussion and the answers will be shared and defended in class. The input that the students can bring to the course will be crucial in this culture. 
3. Visual aids: A video about "celebration" worship will be presented. Students will be able to comment in a guided discussion.

4. Field experience: Each student will have the opportunity to visit different churches in order to evaluate different worship experiences in the Adventist Church and other churches. The students will give a verbal report of their experience to the class and in writing to the teacher.

\section{Basic Outline of the Course}

\section{Course Description}

The course seeks to understand the principles of biblical worship. Foundational aspects will be turned toward application in the church and the pastor's responsibility as the leader of worship. The aim is to help the student further develop competence in these areas, as well as to identify current issues affecting worship practice within the Seventh-day Adventist Church.

\section{Course Objectives}

The course objectives are:

1. To outline the theological principles that should govern the Seventhday Adventist public worship service

2. To provide practical ideas for worship planning

3. To identify the role of the pastor as leader of public worship and its impact on corporate worship 
4. To help the student develop a proper Adventist liturgy which reflects Adventist beliefs and as well as the need for worship revival.

\section{Course Requirements}

Reading

The student is expected to read the book Sing a New Song by

C. Raymond Holmes. He/she is expected to give a reading report.

Class activity

Attendance. Attendance is a must. Unexcused absences are not allowed. Please note that tardiness also counts. Being late three times is considered equivalent to one absence. The final grade will be lowered because of absences.

Participation. The student is expected to participate in class discussions and also to take notes of materials presented in class.

Homework. Write a sermon outline for the eleven o'clock worship service (the topic is on worship).

Write a sermon outline for a church dedication.

Write a sermon outline for a communion service.

Write two pastoral prayers.

Write three benedictions.

Evaluate four worship services (two Seventh-day Adventist, one Protestant, and one Catholic). 
Course Evaluation

\section{Examination}

There will be a one-hour mid-term examination during the last class

period at the end of the eighth week and a one-hour final examination during the final examination week. Examinations will cover the lectures presented in class. Material from the first half of the class will not be repeated in the final examination.

\section{Grading}

The student's grade for the semester will be based on his/her performance:

Class attendance $.10 \%$

Participation $5 \%$

Reading. $.15 \%$

Homework $35 \%$

Mid-term Exam. $15 \%$

Final Exam $20 \%$

The final letter grade will be based on the following percentage:
A $\quad 95 \%$
$\mathrm{C}+\quad 70 \%$
A- $\quad 90 \%$
C $\quad 65 \%$
$\mathrm{B}+\quad 85 \%$
C- $\quad 60 \%$
B $\quad 80 \%$
D $\quad 50 \%$
B- $\quad 75 \%$ 


\section{Course Content}

\section{Week 1}

Class period 1:

Orientation and Introduction; Course Requirements

Class period 2:

Bible and Worship

Class period 3:

Pre-Mosaic Worship

Week 2

Class period 1:

Worship in the Mosaic era

Class period 2:

Worship Experience from Canaan to the Captivity

Class period 3:

Backgrounds for Worship, call to Worship, Definitions

Week 3

Class period 1:

Bases for Worship

Class period 2:

The God We Worship

Class period 3:

The Worshipper

Week 4

Class period 1: $\quad$ Principles of Worship

Class period 2: $\quad$ Response to Revelation

Class period 3: $\quad$ Divine Initiative 
Week 5

Class period 1: $\quad$ Corporate Activity

Class period 2: $\quad$ Values of Worship

Class period 3: $\quad$ Objectivity vs. Subjectivity

Week 6

Class period 1: $\quad$ The Cosmic Conflict and Worship

Class period 2: $\quad$ The Cosmic Conflict and Worship

Class period 3: $\quad$ Created to Worship

Week 7

Class period 1: $\quad$ Mid-term Examination

Class period 2: $\quad$ Worship as an Art

Class period 3: $\quad$ Worship as an Art

Week 8

Class period 1: $\quad$ Liturgy and Ritual

Class period 2: $\quad$ Aesthetic vs. Non-aesthetic

Class period 3: $\quad$ Aesthetic vs. Non-aesthetic

Week 9

Class period 1: $\quad$ Holiness and Time in Worship

Class period 2: $\quad$ Holiness and Time in Worship

Class period 3: $\quad$ The Role of the Minister in Worship 
Week 10

Class period 1: $\quad$ Spiritual Preparation

Class period 2: $\quad$ Physical Preparation

Class period 3: $\quad$ Personality and Skills

Week 11

Class period 1: $\quad$ The Atmosphere of Worship

Class period 2: $\quad$ Principles Governing the Worship Service

Class period 3: $\quad$ Spring Vacation

Week 12

Class period 1: $\quad$ Preparation and Order of Worship

Class period 2: $\quad$ The Bulletin and Public Announcements

Class period 3: $\quad$ Call to Worship

Week 13

Class period 1: $\quad$ The Invocation

Class period 2: $\quad$ Hymns and Music

Class period 3: $\quad$ Prayer and Worship

Week 14

Class period 1: $\quad$ Offering

Class period 2: $\quad$ The Word of God and Worship

Class period 3: $\quad$ The Word of God and Worship 
Week 15

Class period 1:

How to Plan Meaningful Services

Class period 2:

How to Plan Meaningful Services

Class period 3:

Preparation and Creativity

Week 16

Class period 1:

Special Audiences in Worship

Class period 2:

Special Occasions and Worship

Class period 3:

Final Exam 


\section{CHAPTER VI}

\section{EVALUATION OF THE COURSE}

\section{Worship Survey and Its Results (Pretest and Posttest)}

The main purpose of this chapter is to report and evaluate the results of the pretest and posttest obtained in the group that was polled in the Theology School at Montemorelos University. The pretest was given to 47 students and the posttest was given to 57 students taking the class in worship. Ten students were not present at the time the pretest was applied.

I know that in reporting and evaluating a survey, or any other similar instrument, the researcher is confronted with some risks. The researcher does not have control of the laws of behavior and individual differences of each person. The participants were fully informed of the importance of the survey for the writer; that their cooperation was very much needed and that there was anonymity in the answering of the questionnaire, so that they could feel free to answer as they thought best. The respondents answered the way they interpreted the questions.

The questionnaire was given to the third-year students, who are taking training for the B.A. degree in Theology, during the first hour of class, at the beginning of the semester. After the pretest was given I began to develop the 
course in Seventh-day Adventist Worship for pastoral students called "Principles of Worship." There were thirty-one questions in this questionnaire, and these questions covered three main sections. In the first section I specially tried to find out the respondents' understanding of the main components of the Sabbath worship service (bulletin, announcements, call to worship, doxology, invocation, music, prayer, offering, sermon, and benediction). Section 2 dealt with the more general aspects of corporate worship and the responsibility of the pastor as leader of worship. In section 3 the researcher tried to find out the background of each respondent (gender, membership, age, education, ethnic background, and preparation in the Adventist faith).

\section{Students' Understanding of}

Seventh-day Adventist Worship

Table 1 shows the respondent's understanding of a genuine Seventh-day Adventist worship, worship and the Great Controversy, and the understanding of the components of the Sabbath worship service.

The understanding of a genuine Seventh-day Adventist worship is dealt with in question 1 . On the pretest, 82 percent of the students stated that they had a certain degree of understanding. After the course was given, 93 percent of the students stated having an understanding of Seventh-day Adventist worship.

The pretest shows, in question 2 , that 72 percent of the respondents agreed that worship is the key issue in the Great Controversy between God and 
TABLE 1

THE RESPONDENTS' UNDERSTANDING OF SDA WORSHIP

\begin{tabular}{|c|c|c|c|c|c|c|c|c|c|c|c|c|c|c|c|c|c|c|c|c|c|}
\hline \multirow{3}{*}{ Statement } & \multicolumn{10}{|c|}{ Pretest } & \multicolumn{10}{|c|}{ Posttest } & \\
\hline & \multicolumn{2}{|c|}{$\begin{array}{l}\text { Agree } \\
\text { Strongly }\end{array}$} & \multicolumn{2}{|c|}{ Agree } & \multicolumn{2}{|c|}{ Undecided } & \multicolumn{2}{|c|}{ Disagree } & \multicolumn{2}{|c|}{$\begin{array}{l}\text { Strongly } \\
\text { Disagree }\end{array}$} & \multicolumn{2}{|c|}{$\begin{array}{l}\text { Agree } \\
\text { Strongly }\end{array}$} & \multicolumn{2}{|c|}{ Agree } & \multicolumn{2}{|c|}{ Undecided } & \multicolumn{2}{|c|}{ Disagree } & \multicolumn{2}{|c|}{$\begin{array}{l}\text { Strongly } \\
\text { Disagree }\end{array}$} & \\
\hline & \# & $\%$ & \# & $\%$ & \# & $\%$ & \# & $\%$ & \# & $\%$ & \# & $\%$ & \# & $\%$ & \# & $\%$ & \# & $\%$ & \# & $\%$ & \\
\hline $\begin{array}{l}\text { 1. I understand what constitutes } \\
\text { genuine SDA worship. }\end{array}$ & 14 & 30 & 25 & 53 & 6 & 13 & 1 & 2 & 1 & 2 & 20 & 35 & 33 & 58 & 3 & 5 & 1 & 2 & - & - & \\
\hline $\begin{array}{l}\text { 2. Worship is the key issue in } \\
\text { the great controversy } \\
\text { between God and Satan. }\end{array}$ & 16 & 34 & 18 & 38 & 4 & 9 & 6 & 13 & 1 & 2 & 27 & 47 & 21 & 37 & 6 & 11 & 1 & 2 & 1 & 2 & \\
\hline $\begin{array}{l}\text { 3. Do you understand the } \\
\text { purpose of each of these } \\
\text { components of the Sabbath } \\
\text { worship service? }\end{array}$ & & & & & & & & & & & & & & & & & & & & & $\varpi$ \\
\hline a. The bulletin & 20 & 43 & 22 & 47 & 5 & 11 & - & - & - & - & 41 & 72 & 15 & 22 & 1 & 2 & - & - & - & - & \\
\hline b. Public announcements & 29 & 62 & 14 & 29 & 4 & 9 & - & - & - & - & 35 & 61 & 20 & 35 & 2 & 4 & - & - & - & - & \\
\hline c. Call to worship & 24 & 51 & 18 & 38 & 5 & 11 & - & - & - & - & 39 & 68 & 16 & 28 & 1 & 2 & 1 & 2 & - & - & \\
\hline d. The doxology & 21 & 45 & 15 & 32 & 9 & 19 & 2 & 4 & - & $\cdot$ & 37 & 65 & 20 & 35 & - & - & - & - & - & - & \\
\hline e. The invocation & 29 & 45 & 15 & 32 & 9 & 19 & 2 & 4 & - & - & 43 & 75 & 13 & 23 & - & - & 1 & 2 & - & - & \\
\hline f. Hymns and music & 31 & 66 & 16 & 34 & - & - & - & - & - & - & 41 & 72 & 14 & 25 & 1 & 2 & - & - & - & - & \\
\hline g. Prayer & 39 & 83 & 7 & 15 & 1 & 2 & - & - & - & - & 45 & 80 & 12 & 20 & - & - & - & - & - & - & \\
\hline h. Offering & 37 & 79 & 8 & 17 & 2 & 4 & - & - & - & - & 44 & 77 & 11 & 19 & 2 & 4 & - & - & - & - & \\
\hline i. Sermon & 38 & 81 & 7 & 15 & 2 & 4 & - & - & - & - & 46 & 81 & 10 & 18 & 1 & 2 & - & $\cdot$ & - & - & \\
\hline j. The benediction & 34 & 72 & 11 & 23 & 1 & 2 & - & - & - & - & 47 & 82 & 9 & 15 & 1 & 2 & - & - & - & - & \\
\hline
\end{tabular}


Table 1--Continued.

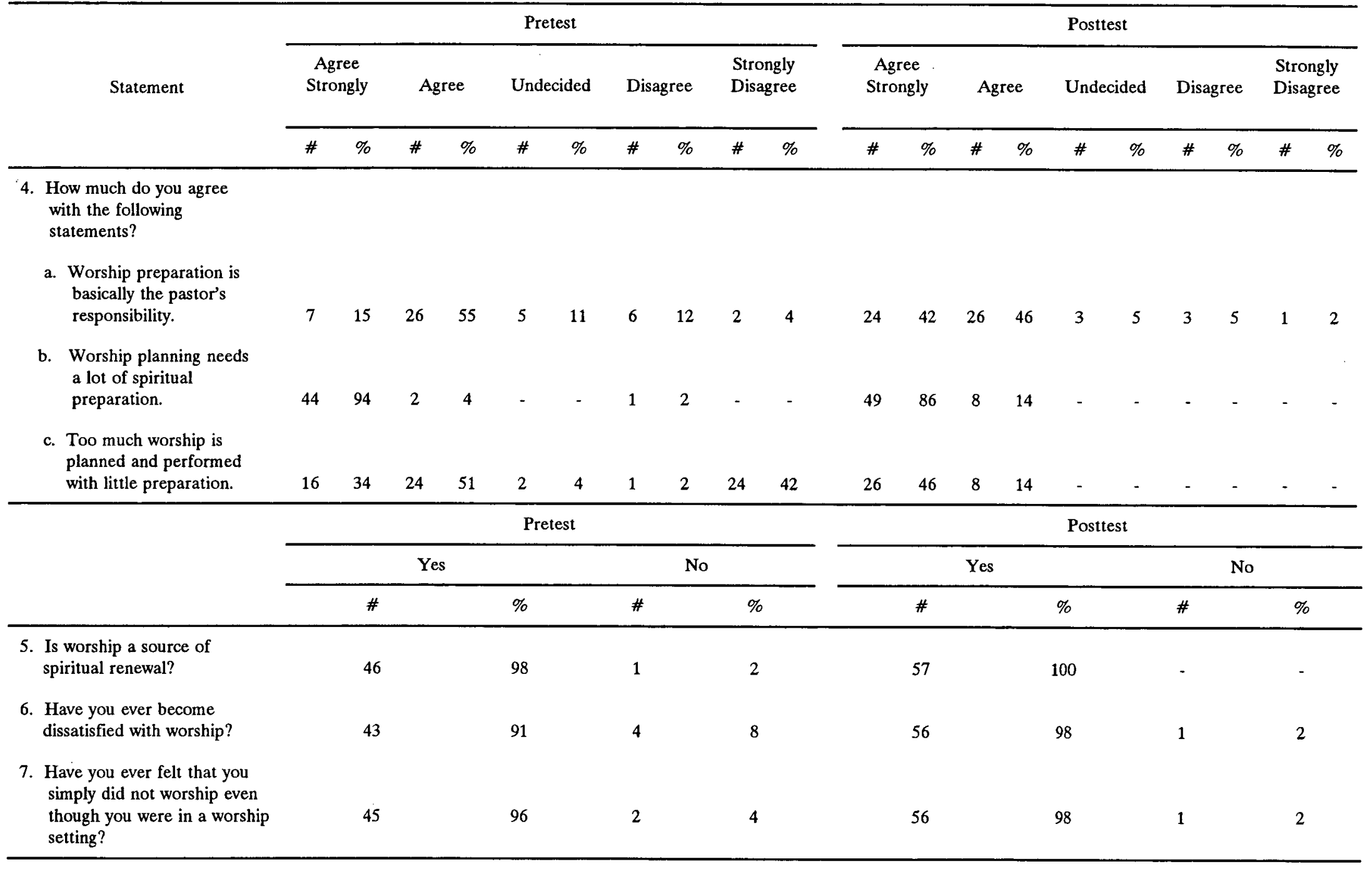


Satan. On the posttest, the percentage of respondents who agreed on this issue increased to 84 .

Ten different components of the Sabbath worship service are dealt with in question 3. The students' responses on their understanding of these ten components are as follows: On the pretest, 90 percent stated they understand the purpose of the bulletin as compared to 98 percent on the posttest. Regarding public announcements, 91 percent stated understanding on the pretest increasing to 95 percent on the posttest. On the pretest 89 percent of the respondents stated understanding of the call to worship compared to 96 percent on the posttest. On the understanding of the doxology, the survey showed a response of 77 percent on the pretest and 90 percent on the posttest. Ninety percent of the students indicated an understanding of the invocation, whereas on the posttest the percentage increased to 98 . The data revealed that on the pretest, 100 percent of the respondents felt they understood the purpose of music in worship, but only 97 percent stated this on the posttest. The meaning of praying was understood by 98 percent on the pretest and 100 percent on the posttest. The percentage of understanding regarding the offering remained the same on both the pretest and posttest, at 96 percent. The answers to the understanding of the sermon in the worship service shows a slight difference of 96 percent on the pretest and 99 percent on the posttest. On the last component, the benediction, 95 percent claimed understanding on the pretest and 97 percent on the posttest. 
Question 4 consists of three items regarding preparation and planning of the worship service. Seventy percent of the respondents manifested that they agreed at least somewhat that worship preparation is basically the responsibility of the pastor in comparison to 88 percent on the posttest. Concerning the need of spiritual preparation of worship-planning, 98 percent stated that they agreed to the necessity on the pretest and 100 percent on the posttest. The last part of question 4 inquired as to the lack of time in preparing spiritually for worship. On the pretest, 85 percent answered they agree or somewhat agree there is little spiritual preparation for worship service against 88 percent on the posttest.

Questions 5 through 7 required a yes or no answer. On the pretest, 98 percent of the respondents stated that worship is a source for spiritual renewal, and 100 percent stated that on posttest; 91 percent manifested having become dissatisfied with worship on the pretest, whereas 98 percent stated so on the posttest; the percentages of the respondents having felt that they simply did not worship even though they were in a worship setting were 96 percent on the pretest and 98 percent on the posttest.

Table 2 shows the respondent's experience in worship during the Sabbath service.

Question 8 inquired as to the extent in which the respondents agreed or disagreed with the statement that the spiritual power in the Sabbath worship service comes from the smoothness of transition. On the pretest, 52 percent 
stated they agreed with the statement, the number increasing to 89 percent on the posttest.

Forty-nine percent of the students on the pretest agreed that the worship leader has so much to think about that there is hardly opportunity to worship personally and 62 percent agreed with that on the posttest.

The answers to question 10 on the pretest reveal that 68 percent agree that the minister, by virtue of his/her calling, is the key person in the service of worship. The answer to this same question on the posttest showed a significant increase in agreement to 93 percent.

The difference between the percentage of respondents that agreed that the leader of worship is obligated to see that he/she is in the best possible physical condition (question 11) was 83 percent on the pretest and 100 percent on the posttest.

The percent of students who agreed that in every hour of public worship there should be a leader who is trained in worship skills (question 12) was 89 percent on the pretest and 100 percent on the posttest.

The importance of not failing in the leadership of worship because it is the most fundamental task of the minister (question 13) was believed by 87 percent on pretest and 98 percent on posttest.

Seventy-three percent agreed on the pretest that worship is a response to the revelation (question 14) in comparison to 88 percent on the posttest. 
That true worship can spring only from the activity of the Holy Spirit (question 15) was accepted by 100 percent on the pretest and 98 percent on the posttest.

The response of worship, like the response of faith, is in itself a gift of God (question 16) was agreed upon by 87 percent of the students on the pretest and 99 percent on the posttest.

On the pretest, 62 percent of the respondents concurred that the doctrine of the priesthood of the believers points to worship (question 17). On the posttest the percentage that concurred rose to 95 percent.

Only a small percentage of 17 agreed on the pretest that public worship is before all things a social act and that this is particularly true of Christian worship (question 18). This percentage increase to 45 on the posttest.

The percentage of respondents on the pretest that felt that worship prepares the church for its work and witness in the world as the body of Christ (question 19) was 87 percent, and on the posttest 97 percent agreed.

That our worship is too human-centered (question 20) was the response of 86 percent of the students on the pretest and 90 percent on the posttest.

A small difference was seen in the percentage of students who agreed on the pretest (96 percent) an on the posttest (100 percent) regarding the presence of God speaking to the minister and acting upon him during worship (question 21). 
It is in worship that God feeds, nourishes, and cares for His children (question 22) was agreed upon by 64 percent on the pretest and 81 percent on the posttest.

Seventy-five percent answered on the pretest that it is in worship that God gives His children His grace, affirms them as members of His community, and sends them forth into the world as His witnesses (question 23) whereas only 71 percent felt this way on the posttest.

Regarding question 24, the need for a renewal in the Adventist way of worship, 66 percent agreed on the pretest and 72 percent agreed on the posttest.

The renewal in Adventist worship is found in the study of the Word of God (question 25) was agreed upon by 92 percent on pretest and 98 percent on posttest.

Table 3 shows the respondents' background. In question 26 , the totality (100 percent) of the students on the pretest and posttest were male.

In question 27 on the length of membership in the Seventh-day Adventist church, the data reveal that 51 percent of the students in the pretest have been members for ten years, and 52 percent on posttest. The difference in responses between older and newer members was evident in the responses to the survey.

The data revealed that all (100 percent) of the respondents had nine grades of education (question 28) on pretest and on posttest.

Question 29 on the ethnic background, the survey showed that 96 percent were Hispanic on pretest, and 98 percent on posttest. 
TABLE 2

EXPERIENCE IN WORSHIP

\begin{tabular}{|c|c|c|c|c|c|c|c|c|c|c|c|c|c|c|c|c|c|c|c|c|c|}
\hline \multirow{3}{*}{ Statement } & \multicolumn{10}{|c|}{ Pretest } & \multicolumn{10}{|c|}{ Posttest } & \\
\hline & \multicolumn{2}{|c|}{$\begin{array}{l}\text { Agree } \\
\text { Strongly }\end{array}$} & \multicolumn{2}{|c|}{ Agree } & \multicolumn{2}{|c|}{ Undecided } & \multicolumn{2}{|c|}{ Disagree } & \multicolumn{2}{|c|}{$\begin{array}{l}\text { Strongly } \\
\text { Disagree }\end{array}$} & \multicolumn{2}{|c|}{$\begin{array}{l}\text { Agree } \\
\text { Strongly }\end{array}$} & \multicolumn{2}{|c|}{ Agree } & \multicolumn{2}{|c|}{ Undecided } & \multicolumn{2}{|c|}{ Disagree } & \multicolumn{2}{|c|}{$\begin{array}{l}\text { Strongly } \\
\text { Disagree }\end{array}$} & \\
\hline & \# & $\%$ & $\#$ & $\%$ & $\#$ & $\%$ & \# & $\%$ & \# & $\%$ & \# & $\%$ & \# & $\%$ & \# & $\%$ & $\#$ & $\%$ & \# & $\%$ & \\
\hline $\begin{array}{l}\text { 8. The spiritual power in the } \\
\text { Sabbath worship service } \\
\text { comes from the smoothness } \\
\text { of transition. }\end{array}$ & 11 & 13 & 14 & 30 & 17 & 36 & 3 & 6 & 2 & 4 & 21 & 38 & 29 & 51 & 5 & 9 & 2 & 3 & - & - & \\
\hline $\begin{array}{l}\text { 9. The worship leader has so } \\
\text { much to think about; there } \\
\text { is hardly opportunity to } \\
\text { worship personally. }\end{array}$ & 5 & 11 & 18 & 38 & 6 & 13 & 7 & 15 & 11 & 23 & 13 & 23 & 22 & 39 & 6 & 10 & 6 & 10 & - & - & \\
\hline $\begin{array}{l}\text { 10. The minister, by virtue of } \\
\text { his/her calling, is the key } \\
\text { person in the service of } \\
\text { worship. }\end{array}$ & 11 & 23 & 21 & 45 & 2 & 4 & 7 & 15 & 11 & 23 & 46 & 81 & 7 & 12 & 3 & 5 & - & - & . & - & N \\
\hline $\begin{array}{l}\text { 11. The leader of worship is } \\
\text { obligated to see that he/she } \\
\text { is in the best possible } \\
\text { condition. }\end{array}$ & 29 & 62 & 10 & 21 & 4 & 9 & 2 & 4 & 2 & 4 & 41 & 72 & 16 & 28 & - & - & - & - & . & - & \\
\hline $\begin{array}{l}\text { 12. In every hour of public } \\
\text { worship, there should be a } \\
\text { leader who is trained in } \\
\text { worship skills. }\end{array}$ & 28 & 60 & 14 & 30 & 3 & 6 & 1 & 2 & 1 & 2 & 42 & 74 & 15 & 26 & - & - & - & - & - & - & \\
\hline $\begin{array}{l}\text { 13. The minister must not } \\
\text { allow himself/herself to fail } \\
\text { in the leadership of worship } \\
\text { this is his/her most } \\
\text { important task in ministry. }\end{array}$ & 27 & 57 & 14 & 30 & 3 & 6 & 2 & 4 & 1 & 2 & 44 & 77 & 12 & 21 & - & - & - & - & - & - & \\
\hline
\end{tabular}




\section{Table 2--Continued.}

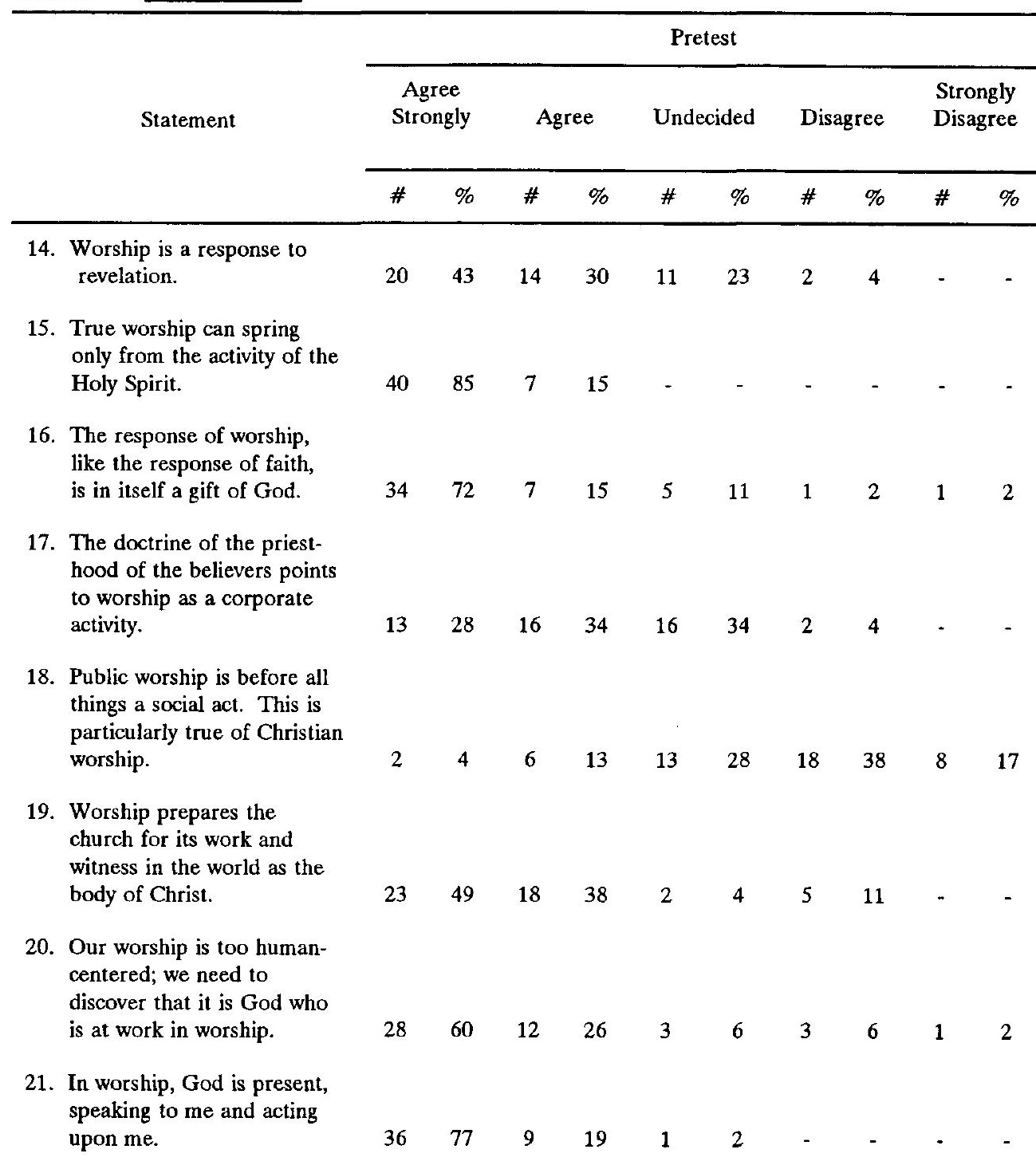


Posttest

Agree Strongly

Strongly Agree Undecided Disagree Disagree

$\begin{array}{llllllllll}\# & \% & \# & \% & \# & \% & \# & \% & \# & \%\end{array}$

$\begin{array}{llllllll}28 & 49 & 22 & 39 & 6 & 10 & 1 & 1\end{array}$

$\begin{array}{lllllllll}49 & 86 & 7 & 12 & - & - & 1 & 2 & -\end{array}$

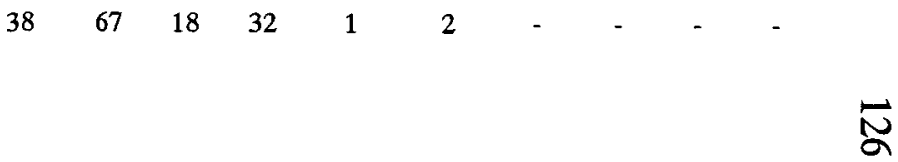

$\begin{array}{llllllllll}37 & 65 & 17 & 30 & 2 & 3 & - & - & 1 & 2\end{array}$

$\begin{array}{llllllllll}11 & 19 & 15 & 26 & 17 & 30 & 6 & 10 & 8 & 14\end{array}$

$\begin{array}{llllll}38 & 67 & 17 & 30 & 1 & 2\end{array}$

$\begin{array}{llllllll}30 & 53 & 21 & 37 & 3 & 5 & 3 & 5\end{array}$

$\begin{array}{llll}43 & 75 & 14 & 25\end{array}$ 
Table 2--Continued.

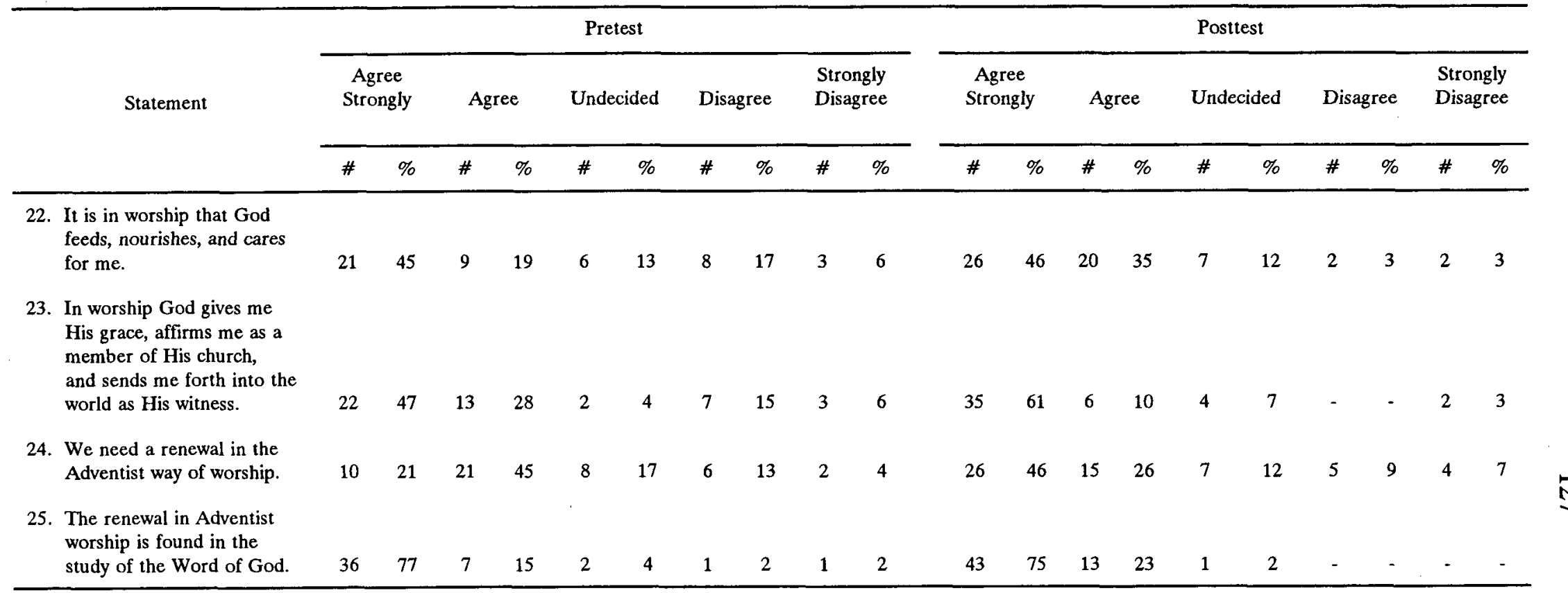


TABLE 3

THE RESPONDENTS' BACKGROUND

\begin{tabular}{|c|c|c|c|c|}
\hline \multirow{2}{*}{ Questions } & \multicolumn{2}{|c|}{ Pretest } & \multicolumn{2}{|c|}{ Posttest } \\
\hline & \# & $\%$ & \# & $\%$ \\
\hline
\end{tabular}

26. What is your gender?

Male

Female

27. How long have you been a baptized Seventh-day Adventist?

Less than a year

1 to 5 years

6 to 10 years

11 to 20 years

over 20 years

28. Highest level of formal education that you have completed.

Elementary school

Secondary school

Preparatory school

47

Some college

47

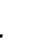

$-$

7

17

15

8

100

57

100

(1)

15

36

32

17

17

15
6
7
7

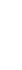

7

12

23

40

15

26

13

22 
Table 3--Continued.

Questions $\quad$\begin{tabular}{c} 
Pretest \\
\cline { 2 - 6 }
\end{tabular}

29. What is your ethnic background?

Asian/Oriental

Black

Hispanic

45

96

56

98

White

Other

$-$

-

1

30. What is your age?

Under 18

$18-24$

-

$25-34$

35 or older

31. I received adequate instruction in the Adventist faith before joining the church.

Agree strongly

Agree

\begin{tabular}{cccc}
38 & 81 & 46 & 81 \\
9 & 19 & 11 & 19 \\
- & - & - & - \\
& & & \\
18 & 38 & 17 & 30 \\
17 & 36 & 21 & 37 \\
5 & 11 & 6 & 11 \\
4 & 9 & 8 & 14 \\
3 & 6 & 5 & 8 \\
\hline
\end{tabular}

Undecided

Disagree

Disagree strongly 
A significant finding is that 81 percent of the students were between 18 and 24 years of age on pretest (question 30); on posttest this percentage was the same. This is an important factor because age is related to religious insight.

Older people, in general, are less likely to change than younger persons, but this has not been tested in relation to worship as far as I know.

About three-fourths ( 74 percent) of the respondents manifested that they agreed on pretest at least somewhat that they received adequate instruction in the Adventist faith before joining the church (question 31), and 67 percent agreed on posttest. Here we have a situation that might have to do with how the respondents interpreted the question, or the laws of behavior and individual differences which are beyond the control of the researcher. 


\section{CHAPTER VII}

\section{CONCLUSIONS AND RECOMMENDATIONS}

\section{Conclusions}

A project becomes meaningful if it carries the appropriate values at a needed place and a needed time. It should serve one purpose: To meet the needs of people. Although one recognizes that this contribution is limited in comparison to the task that ought to be accomplished, one trusts that it will not have been done in vain.

Montemorelos University, where this program will be implemented, should certainly benefit from the research. I remember that in my own experience as a member of the Seventh-day Adventist Church, I was not prepared to take my place in the worship of an Adventist congregation in a meaningful and understanding way. This project should contribute to a better understanding of Seventh-day Adventist worship, and to better awareness of the necessity of pastors, the leaders of worship, to know the centrality of worship in the great controversy and to pay more attention to membership preparation. There is strong need to prepare pastors for worship planning, leadership, and renewal in the Seventh-day Adventist Church in Mexico. 
The Seventh-day Adventist Church recognizes the centrality of worship in the Great Controversy and for this reason Ellen G. White, several years ago, stated: "An enemy has been at work to destroy our faith in the sacredness of Christian worship." ${ }^{11}$ This statement is more relevant during the nineties because it is a period when values have been destroyed. It is an era of uncertainty, of dryness, of fear, and anguish, yet a time in which people are crying out for more spirituality. The need to have a sense of belonging and they need hope, and if they cannot find them in the agency provided by God, where are they going to find them?

The church is the only place where the basic questions about life are asked and answered. Talking about deep problems of society, such as drugs, abortion, homosexuality, and how far from God humanity has gone, Tony Anatrella, psychoanalyst, sees the solution in the transmission of strong values. He writes: "The object of the debate should be the transmission of morals and faith."

He also suggests that the Christian society should go back to its origins, and not be ashamed of its heritage. "We live as if we had no more roots, as if we were ashamed of Christianity, from our past, from our fathers, from our origins,"

${ }^{1}$ White, Testimonies for the Church, 5:496.

${ }^{2}$ Robert Serrou, "Nous payons cher la mort de Dieu," Paris Match, March 25, 1993, cited in Bruno R. Vertallier, "A Design for Spiritual Formation During the Academic Life of the Adventist Seminary Students at Collonges-Sous-Salève, France" (D. Min. dissertation, Andrews University, 1993), 126. 
holds Anatrella. ${ }^{1}$ The depression of current society has deep spiritual origins. The cry of a dying planet must be heard, and the hope is to rediscover and share spiritual values.

We spend millions of dollars on evangelism, and rightly so. We engage in lay activities; this is good. But we have departed from the finest possible missionary activity--bringing our non-Adventist friends to our churches--by a failure to provide worshipful Sabbath services. ${ }^{2}$ Administrators, pastors, and teachers have forgotten the important request of Jesus to Peter to "feed my sheep and lambs." What is the answer to the problem of worship in our churches? It will not be found in ignoring the problem. If it is true that an enemy is trying to destroy the sacredness of Christian worship, we need to do something about it. Contentment with confusion, meaninglessness, and immaturity will not defeat this enemy.

The answer will be found in (1) a thorough knowledge of the biblical theological, and historical aspects of Christian worship, and (2) a thoughtful application of this knowledge to Adventist worship today. We must prepare pastors for worship planning, leadership, and renewal in the Seventh-day Adventist Church. ${ }^{3}$

${ }^{1}$ Ibid., 4.

${ }^{2}$ Pease, 8.

${ }^{3} \mathrm{Ibid}$. 
Our ministers and our people, by and large, love God and want to worship Him. Many know the reasons for observing the Sabbath. They have sacrificed much to observe a day of worship, but they have often failed to inform themselves regarding the way of worship.

This project report attempts to encourage a reflection on the necessity of permitting the Holy Spirit to guide the lives of the seminarians to sense the need for a renewed commitment to the Lord and to decide to become real pastors of the flock.

The best reward would be to see seminary students transformed by the love and the grace of God, and to become real leaders of worship. To rediscover the purpose and power of true worship, to discover how to bring the people to the altars of the Eternal for inspiration, and then to set their feet free in the highways of service to their fellowmen, this is a challenge to the ministry for these difficult days.

\section{Recommendations}

The spiritual formation of pastors, even if under the responsibility of the seminary, should be a church concern. A recommendation would be to study the impact that spiritual leaders recently out of the seminary could have on local congregations.

Acknowledging the real need of worship leaders in this field, it is also recommended to prepare a seminar for pastors already in the field and for the lay people in their churches. It is imperative to have trained worship leaders in every 
local church. It is the desire of all members to discover some practices that would allow them to walk and grow in the Spirit. In association with the seminary, the local conference of the Seventh-day Adventist Church could begin promoting worship seminars. The procedure could be the following:

1. Appoint one person at the seminary and one in the conference with special interests in worship matters. These individuals should develop a strategy that would allow them to present, on weekends at special workers' meetings, the principles of worship. These persons should have a sensitivity to the needs of individuals and congregations, and should deploy their skills to bring renewal in one's life and ministry.

2. During the year, weekends should be offered for adults, youth and children. Pastors should prepare special services for their congregations. They could also give opportunity to different people to participate. Hopefully this would bring a positive approach to worship as the congregation learns the reason why and how they can worship God in spirit and truth.

3. Encourage worship leaders to plan each part of worship ahead of time, and do their very best to give our God the honor and glory that only He deserves. Pastors should include in their plans each year a weekend for training the church in this matter.

The Seventh-day Adventist Church must by all available means support the spiritual development of its pastors and members. It must always encourage inspiring worship services that will witness to the cause of preaching the gospel, 
and above all, bring glory to God. We must remember that the success of the church to which we are devoting our lives depends to a great extent on what happens between eleven and twelve o'clock on Sabbath mornings. 


\section{APPENDIX A}

\section{WORSHIP CLASS SURVEY}

The following survey is designed for students taking training for the degree B.A. in Theology at Montemorelos University, Mexico.

*Circle the number of the answer you choose.

1. I understand what constitutes genuine Seventh-day Adventist worship.

1. Agree strongly

2. Agree

3. Undecided

4. Disagree

5. Disagree strongly

2. Worship is the key issue in the great controversy

1. Agree strongly between God and Satan.

2. Agree

3. Undecided

4. Disagree

5. Disagree strongly

3. Do you understand the purpose of each of these components of the Sabbath worship service?

$1=$ Definitely yes $\quad 2$ = Possibly yes $\quad 3=$ Possibly no $\quad 4=$ Definitely no
a. The bulletin
b. Public announcements
c. Call to worship
d. The doxology
e. The invocation
f. Hymns and music
g. Prayer
h. Offering
i. Sermon
j. The benediction

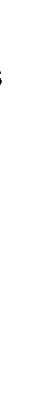

4. How much do you agree with the following statements?

$1=$ Strongly agree 2 = Somewhat agree $3=$ Uncertain $4=$ Somewhat uncertain $5=$ Strongly disagree 
Worship preparation is basically the responsibility of the pastor.

Worship planning needs a lot of spiritual preparation.

Too much worship is planned and performed with little spiritual preparation.

5. Is worship a source for spiritual renewal?

$\begin{array}{ll}\text { Yes } & \text { No } \\ \text { Yes } & \text { No } \\ \text { Yes } & \text { No }\end{array}$

6. Have you ever become dissatisfied with worship?

7. Have you ever felt that you simply didn't worship even though you were in a worship setting?

No

How much do you agree with the following statements?

$1=$ Agree strongly $2=$ Agree $3=$ Undecided $4=$ Disagree $5=$ Disagree strongly

8. The spiritual power in the Sabbath worship service comes from the smoothness of transition.

$\begin{array}{lllll}1 & 2 & 3 & 4 & 5\end{array}$

9. The worship leader has so much to think about; there is hardly opportunity to worship personally.

$\begin{array}{llllll}1 & 2 & 3 & -4 & 5\end{array}$

10. The minister, by virtue of his/her calling, is the key person of worship.

$\begin{array}{lllll}1 & 2 & 3 & 4 & 5\end{array}$

11. The leader of worship is obligated to see that he/she is in the best possible physical condition.

$\begin{array}{llll}2 & 3 & 4 & 5\end{array}$

12. In every hour of public worship, there should be a leader who is trained in worship skills.

$\begin{array}{lllll}1 & 2 & 3 & 4 & 5\end{array}$

13. The minister must not allow him/herself to fail in the leadership of worship, for this is the most fundamental of his ministerial tasks.

14. Worship is a response to revelation.

$\begin{array}{lllll}1 & 2 & 3 & 4 & 5 \\ 1 & 2 & 3 & 4 & 5 \\ 1 & 2 & 3 & 4 & 5\end{array}$

15. True worship can spring only from the activity of the Holy Spirit.

16. The response of worship, like the response of faith, is in itself a gift of God.

$\begin{array}{lllll}1 & 2 & 3 & 4 & 5\end{array}$

17. The doctrine of the priesthood of the believers points to worship as a corporate activity.

$\begin{array}{lllll}1 & 2 & 3 & 4 & 5\end{array}$

18. Public worship is before all things a social act. This is particularly true of Christian worship.

$\begin{array}{lllll}1 & 2 & 3 & 4 & 5\end{array}$

19. Worship prepares the church for its work and witness in the world as the body of Christ.

$\begin{array}{llll}2 & 3 & 4 & 5\end{array}$


20. Our worship is too human-centered; we need to discover that it is God who is at work in worship.

\section{1}

21. In worship, God is present, speaking to me and acting upon me.

1 cares for me.

23. It is in worship that God gives me His grace, affirms me as a member of His community, and sends me forth into the world as His witness.

24. We need a renewal in the Adventist way of worship.

25. The renewal in Adventist worship is found in the study of the Word of God.

Please circle the number of the answer you choose.

26. What is your gender?

\section{Male Female}

27. How long have you a baptized Seventh-day Adventist?

1. Less than a year

2. 1 to 5 years

3. 6 to 10 years

4. 11 to 20 years

5. over 20 years

28. Highest level of formal education that you have completed.

1. Elementary school

2. Secondary school

3. Prep school

4. Some college

29. What is your ethnic background?

1. Asian/Oriental

2. Black

3. Hispanic

4. White

5. Other

30. What is your age?

1. Under 18

2. $18-24$

3. $25-34$

4. 35 or older

1. Agree strongly

2. Agree

3. Undecided

4. Disagree

5. Disagree strongly 


\title{
APPENDIX B
}

\section{SIX CLASSROOM PRESENTATIONS}

\author{
The Cosmic Conflict and Worship
}

\section{General Introduction}

A. "O come, let us worship and bow down: let us kneel before the Lord our maker" (Ps 95:6).

B. "Yet a time is coming and has now come when the true worshippers will worship the Father in spirit and truth, for they are the kind of worshippers the Father seeks. God is spirit, and his worshippers must worship in spirit and in truth" (John 4:23, 24).

C. A last-day call (Rev $14: 7)$.

1. Chronology of this passage (vs 14).

2. The proclamation of the judgment hour message includes a recall to the worship of God.

3. "Worship the Lord your God, and serve him only" (Matt 4:10).

II. The Advent Message a Call to Universal Worship

A. Those who proclaim the Judgment Hour message must interpret prophecy. But more, they must inspire the Spirit of Worship in the hearts of those who hear.

B. Our work is twofold:

1. To convince men of arrival of judgment hour.

2. To call men out of Babylon to the worship of Him who made heaven and earth. 
3. Every feature of Advent message--doctrine, precept, prophecy-should lead men and women and boys and girls to worship.

4. Mere activity is not worship, but true worship leads to joyous activity for God and His church.

5. Emphasis must not be on work alone. It is true that there is a great work to be done, but there is also a great God to be worshipped.

6. We are specialists in training our congregations to work. Should we not also be specialists in training our congregations to worship? Training congregations to work is not our only responsibility. We must teach them to worship. "The true worshippers shall worship the Father in spirit and in truth: for the Father seeketh such to worship Him" (John 4:23). The Father needs workers, but $\mathrm{He}$ is seeking worshippers. Better worship leads to better work.

7. Worship is first of all an experience. It may express itself through certain forms, but "it is not primarily a form; it is an experience."

8. True worship embraces the whole personality of man--though, emotion, will, and strength. "Bless the Lord, O my soul: and all that is within me, bless his holy name" (Ps 103:1).

\section{The Cosmic Conflict and Worship}

A. Before the entrance of evil there was peace and joy throughout the universe. All was in perfect harmony with the Creator's will.

B. Christ the Word, the only-begotten of God, was one with the eternal Father--one in nature, in character, and in purpose--the only Being in all the universe who could enter into all the counsels and purposes of God.

C. "Sin originated with him who, next to Christ, had been most honored of God and who stood highest in power and glory among the inhabitants of heaven. Before his fall, Lucifer was first of the covering cherubs, holy and undefiled" (White, GC, 493, 494).

D. "This is what the Sovereign Lord says: You were the model of perfection, full of wisdom and perfect in beauty. You were in Eden, 
the garden of God; every precious stone adorned you." "You were anointed as a guardian cherub, for so I ordained you. You were in on the holy mount of God; you walked among the fiery stones. You were blameless in your ways from the day you were created, till wickedness was found in you" (Ezek 28:12-15)

E. Little by little, Lucifer came to indulge a desire for self-exaltation. "Thou has set thine heart as the heart of God." "Thou has said . . . I will exalt my throne above the stars of God: I will sit upon the mount of the congregation. ... I I will ascend above the heights of the clouds; I will be like the most high" (Isa 14:13, 14).

F. "Pride in his own glory nourished the desire for supremacy. The high honors conferred upon Lucifer were not appreciated as the gift of God and called forth no gratitude to the Creator. He gloried in his brightness and exaltation, and aspired to be equal with God" (White, GC, 195).

G. Lucifer was seeking merely the exaltation of himself. He was against God's government. "Satan's rebellion was to be a lesson to the universe through all coming ages, a perpetual testimony to the nature and terrible results of sin" (Ibid., 199).

H. The whole universe must see the deceiver unmasked, the one who wants the worship and honor that belongs to Jesus. "Therefore it must be demonstrated before the inhabitants of heaven, as well as of all the worlds, that God's government was just, His law perfect" (Ibid., 198).

I. "The mighty argument of the cross demonstrates to the whole universe that the course of sin which Lucifer had chosen was in no wise chargeable upon the government of God" (Ibid., 501).

J. At the heart of God's final message is a call to worship (Rev 14:7).

K. Those who proclaim the Judgment Hour message must understand prophecy chronologically and symbolically.

L. The purpose of worship is to lead the human spirit Godward. Worship is adoration of the Infinite.

M. "An enemy has been at work to destroy our faith in the sacredness of Christian worship" (White, 5T, 496). 
N. Leading men to "worship Him who made heaven and earth" is the real work of the minister. Unless we do that, we have failed.

\section{Created to Worship}

Introduction

A. The innate desire to worship is universal in man. It is a law of man's nature, written into his essence.

B. Whatever faith man holds, he remains essentially a worshipping creature. He worships either God or himself.

C. At the very heart of the Advent message is a call to "worship him that made heaven, and earth." The fact that this command is given in the setting of God's last call to a world in rebellion is evidence that the meaning of true worship has been either perverted or forgotten.

D. Worship is more than organization, arrangement, or technique. It springs from the depths of the human soul and is inspired by an awareness of the presence of God.

I. The Nature of Man

A. The implication of Divine Origin. "Let us make man" implies God is the absolute source of man's life and being. His life is essentially a divine gift.

B. "In His image" implies a close relationship between creature and Creator. Outside this relationship, humanity would cease to be. The close relationship is expressed in a unique affinity characterized by man's capacity and appetite for God.

C. "In His image" implies that man is a religious and social being seeking fellowship with God as his highest joy.

D. David wrote of this experience of man: "As the deer pants for the streams of water, so my soul pants for you, O God" (Ps 42:1 NIV).

E. Augustine (d. 430 A.D.) echoes the same thought when he prays, "Thou hast made us for thyself, and our hearts are restless till they rest in thee." Being created in the image of God, man in his meaning and 
purpose of life finds his ultimate relationship, fulfillment, and satisfaction in his Divine Maker.

F. "In His image" implies man is unique and distinct from animals. Yet he is never a divine man or a demi-god.

G. The unique nature of man lies in the special, divinely endowed spiritual nature that enables him to discern, understand, and respond to the spiritual things of the God who is spirit.

H. The very unique act of God forming the physical body of man with His own hands clearly indicates that man is a holistic human being. Man in God's image is to relate to his Maker holistically--spiritually, mentally, and physically.

II. The Implication of Responsible Human Existence

A. "You may freely eat of every tree of the garden; but of the knowledge of good and evil you shall not eat, for in the day you eat of it you shall die" (Gen 2:16, 17). Explicit command to man from God.

B. Created in God's image, man has a moral responsibility to God's law that regulates relationship.

1. In obedience to God's law, as responsible being, man enjoys true freedom in God and His world.

2. Disobedience destroys that relationship and ushers in death.

3. The whole created order is made for God's glory (cf. Isa 6:3; Ps 19).

a. It is, however, to man who is given the highest privilege and moral duty to reflect and to reveal the character of his Divine Maker.

b. Humanity made in God's image clearly implies that humanity has the potential to reveal God.

c. "Man, in contrast from all the rest of creation, has not merely been created by and through God, but in and for God. He is, who he is originally, by God and through God; he is also in and for God. Hence he can and should understand himself in God alone. Just as it is said of no 
other that it has been created "after his likeness" or "in his image" (Emil Brunner, Man in Revolt; A Christian Anthropology, 92).

4. Thus "in His image" implies a responsible human existence through a relationship of love and obedience to God.

5. "In His image" also implies man's responsible relationship with his fellowman.

6. When Scriptures say that "a man leaves his father and his mother and cleaves to his wife, and they become one flesh" (Gen 2:24), it gives expression to the principle of love as the law of life in nothing less than the covenant of love in the marriage institution. Karl Barth sees in this love principle the "definitive explanation of the image of God" (Church Dogmatics, III. 1, 195).

III. The Implication for Faith in the Divine-Human Encounter

A. In the presence of His Creator, man's first inclination is to trust Him, first, in terms of the revelation that he had been created by God, and then in obedience to God's direction that he be "fruitful and multiply, and fill the earth and subdue it" (Gen 1:28).

B. Faith, however, is substantiated with evidence of divine providence and provision for the continuance of life when God, addressing Adam and Eve, said, "Behold, I have given you every plant yielding seed which is upon the face of all the earth, and every tree with seed in its fruit; you shall have them for food" (Gen 1:29).

C. Faith as a basic love relationship is implied in the relationship of marriage and by the extension to all interpersonal relationships that issue from the marriage institution.

D. Faith as a living and growing relationship, however, must meet the crucible of obedience to God (Gen 2:17).

E. Instinctively, faith is a compelling force in the face of the Creator God who is mighty, good, and compassionate.

F. Man who is created in God's image is unique yet of divine origin. He is distinct and independent, yet in close affinity and utter dependence upon divine sustenance. 
G. Man is a free moral agent, yet with the divine gifts of love and faith he is to live in responsible relationship with God and man.

H. Redemption and restoration began with God seeking man (Gen 3:9). An every possibility for communion between God and man has as its basis redemption through divine initiative.

I. The provision of a human-divine Redeemer based solely upon the initiative of the divine clearly indicates a salvation by divine grace to which man can only respond either with faith in acceptance or with unbelief in rejection.

J. Acceptance by faith of divine grace implies partaking also of the divine triumph over Satan--resurrection and life.

K. Rejection by disbelief would likewise imply partaking of the fatal defeat of Satan--destruction and death.

L. The redemptive covenant thus contains the proto-evangelism, the first glimmer of the gospel. It became the new basis for faith, hope, and worship communion.

M. The object of all true worship is God. The quality of worship is determined by one's conception of God and his relationship with Him.

N. Through an awareness of God as Creator, as Lord, as Redeemer, and as Father of man "in His image," man's response to Him is one of worship.

O. Hence worship is rational and inevitable. It is born of the nature and needs of the human soul. Such a worship is to be characterized with awe, amazement, and reverence interwoven with adoration, love, gratitude, and faith. Such are the essential ingredients of true worship.

P. The duty to worship God is based upon the fact that He is the Creator and that to Him all other beings owe their existence. And ... His claim to reverence and worship, above the gods of the heathen, is presented, there is cited the evidence of His creative power (White, GC, 437). 
Holiness and Time in Worship

Introduction

The centrality of time in Christian worship tells us a great deal both about Christianity itself and about Christian worship. It tells us that Christianity is a religion that takes time seriously (James F. White, Introduction to Christian Worship, 44).

The Sabbath was a gift from God to all His people to establish and perpetuate true worship through time and eternity. This gift was not just for a selected few, but for all mankind at all times.

It is not possible for a Seventh-day Adventist to think about worship or to participate in worship without reference to the Sabbath and its meaning. As one of the three major biblical doctrines which identify Adventists, the Sabbath should be liturgically dramatized and illustrated in every worship service (C. R. Holmes, Sing a New Song, 27).

I. The Christian Understanding of Time

A. The Greek view of time. The two important words used in the Greek language to describe time are: kairos and chronos.

${ }^{*}$ Kairos designates a moment of importance and may refer to special times such as the time of birth, the time of marriage, the time of death.

${ }^{*}$ Chronos refers to the time between special events and may be appropriately designated as the time of sequence or chronology.

B. From a philosophical point of view, there were two distinguishing characteristics of time among the Greeks:

1. Greek philosophers separated time (as bound to creation) from timelessness (as above creation). Because of this separation, that which is eternal or above time cannot enter into time. Thus, it has no eternal or ontological meaning; it is a prison in which man is held.

2. The Greeks had the notion that time is cyclical. It has no goal. It is not proceeding toward a final moment (kairos) that will give meaning and purpose to the chronology of time. Thus, history 
and man are doomed to an eternal recurrence of time. This pessimistic view sees time without meaning outside of those existential events that a particular person may find meaningful for his or her existence (Robert E. Webber, Worship Old \& New, $161,162)$.

\section{The Hebraic Concept of Time}

A. The ancient Hebrew people also had a sense of time characterized by chronos and kairos. However, their view differed significantly from that of the Greeks because Hebrews held a theological world view. They were committed to the existence of a transcendent God who makes Himself present in time through historical action.

B. The first mark of Hebraic time is that it is defined by historical events. These events are a series of special moments (kairoi) that represent the saving acts of Yahweh. For example:

1. The time of Moses and the Exodus out of Egypt (Deut 1:9, 16, $18 ; 2: 33-34 ; 3: 3-4 ; 4: 4 ; 6: 6 ; 9: 19)$.

2. The reign of David (1 Chr 21:28-29).

3. The building of Solomon's temple (2 Chr 7:8).

C. Throughout the OT a strong interest is shown in history, especially the details of those events that mark the action of Yahweh on behalf of the people of Israel (see Neh 1:5-9); Ps 78; Jer 11:1-5).

D. For the Hebrews, time was not empty of meaning, for it was in the time-oriented events of history that God was at work accomplishing His will and purposes through the people of Israel.

E. The second mark of Hebraic time is its emphasis on prophecy. Time is rooted not only in the past events, such as the Exodus, but also in the future events toward which it is moving.

F. The events that have already occurred in time contain an element of expectation, of hope, of fulfillment, and even judgment.

G. A number of significant features of Hebraic time result from the emphasis on historical events and prophecy. 
1. The Hebraic approach recognizes the presence of the eternal in time. Time and eternity are not antithetical concepts. Rather, God, who created time, is active in time, moving it toward the fulfillment that $\mathrm{He}$ intends.

2. Consequently, time is an integral structure of God's reality. For this reason events in time have real and ultimate meaning. They are not the result of chance but the evidence of God's benevolent care and purpose for His creation.

III. The Christian Understanding of Time

A. The Christian understanding of time also uses the concepts of chronos and kairos, maintaining the distinction given to them in Greek, but viewing them in a manner similar to the Hebraic usage.

B. The unique feature of the Christian conception of time is the major moment (kairos) through which all other kairoi and chronoi find their meaning. This unique moment is the incarnation, death, resurrection, and the second coming of Christ.

C. In Christianity, all time has a center.

1. Christ is the creator of all things ( $\mathrm{Col} 1: 16)$.

2. The One in whom all things hold together (Col 1:17).

3. The One through whom all things are reconciled (Col 1:20).

D. Christ is the cosmic center of all history. Everything before Christ finds fulfillment in Christ. Everything since Christ finds its meaning by pointing back to Christ.

1. Fulfilled time. The incarnation of God in Christ represented the fulfillment of the Old Testament messianic longings (Mark 1:15).

2. The coming of Christ is the time of salvation. Jesus' death was the moment of victory over $\sin (\mathrm{Col} \mathrm{2:15;} 2 \mathrm{Chr} 6: 2)$.

3. The Christ-event introduces the Christian anticipatory time. This aspect of time is based on the resurrection, the ascension, and the promise of Christ's coming. Again. Consequently, the church, like the OT people of God, lives in anticipation of the future (1 Tim 6:14; John 5:28-30; 1 Cor 4:5; 1 Pet 4:17; Rev 11:18). 
E. This Christian conception of time is important because it plays a significant role in the worship of the church. The historic and unrepeatable Christ-event is the content which informs and gives meaning to all of time.

F. In worship we sanctify present time by enacting the past event of Jesus in time which transforms the present and gives shape to the future (Robert E. Webber, Worship Old \& New, 161-165).

\section{The Sabbath Day}

A. Christianity is a religion of time before space.

1. In the beginning of earth's history God did not consecrate a place for His dwelling. Rather, He consecrated a period of time in which His creatures were to meet Him in fellowship and communion.

2. He made man a steward of time as well as of life and of tangible created things.

B. The Sabbath reminds us of the sacredness of all time and of that day in particular. The Sabbath reminds us that we are stewards of God's gift of time as well as of His material gifts.

1. It reminds us to use the gift of time to the glory of God and the edification and well-being of mankind.

2. Time is a sacred as life itself.

C. As we maintain the holiness of time, we maintain the holiness of life.

1. For Sabbath keepers, this is particularly true. To give lip service to the Seventh-day Sabbath, the evidence of God's claim on our time, and to spend time in any unholy activity on the Sabbath or any other day, is to desecrate the whole concept and purpose of the holiness of time.

2. Man's misuse of time is not limited to the Sabbath. Just as he corrupts life, man corrupts all time (Rom 1:25, TEV).

D. Worship, particularly corporate worship during the Sabbath, time God has set aside for just that purpose, is one of these concrete acts that makes faith visible. 
1. In worship, the believer observes the sacredness of Sabbath time (and all time), hears the Word again, renews his vow of faith and commitment, and chooses to live obediently in time and space.

E. The Sabbath reminds us of creation, when God Gave us the time we have now, and redemption, in which He gives us all eternity.

1. The celebration of creation and redemption, to which the Sabbath points, is the focus of worship for the church of the last days.

2. The worshipping church is called to "remember" when it gathers on Sabbath morning.

F. The perpetual nature of the Sabbath in time and eternity reminds us of the faithfulness of God over against our unfaithfulness.

1. The Sabbath comes faithfully every seventh day, whether we acknowledge it or not.

2. God is faithful, though we are unfaithful. He keeps His promises.

G. Faith can only be expressed by specific acts in time and space.

Worship provides one opportunity to affirm our faith by our actions.

1. As we worship we enter into the holiness of sacred time and participate in its blessings.

2. Renewed by this remembrance of God great gift, we leave the worship service to live our faith in the time God gives us for the days to come. 


\section{Preparation and Order of Worship}

\section{Introduction}

"Nothing that is sacred, nothing that pertains to the worship of God, should be treated with carelessness or indifference" (White, 5T, 491).

To rediscover the purpose and power of real worship, and to know how to "bring the people to the alters of the Eternal for inspiration, and then set their feet free in the highways of service to their fellowmen"--this is the outstanding need of the ministry in this crisis hour of human history.

Worship is more than attending church, singing hymns, saying prayers, reading or listening to the Word of God expounded. These all have a place in true worship, but in themselves are not necessarily worship. In fact, any or all of them, if carried out in a wrong way, may actually destroy the spirit of worship.

\section{Worship Preparation}

A. "One of the explanations for much ineffective worship in our churches is the lack of serious planning on the part of leaders" (Segler, Christian Worship, 185).

B. This carelessness in planning may be due to the following facts: Some leaders in worship have closed minds on the subject; their knowledge of the dynamics of participation may be limited; their poor theologizing about worship sets it apart as being irrelevant (Ibid.).

C. Our congregations are responsible too. They make an enormous difference with their prayers and enthusiasm and healthy participation. But they are not the leaders and hardly can be expected to provide the thrust toward more spiritual services.

D. Worship preparation is basically the pastor's responsibility. If we do not prepare spiritually for worship, it is highly unlikely that the Spirit will be felt in the service, or that the individual parts of the liturgy will rise and converge into an exciting whole.

E. "His service should be made interesting and attractive and not be allowed to degenerate into a dry form" (White, $\underline{5 T}, 609$ ). 
F. "God is not a God of confusion" (1 Cor 14:33). "Let all things be done properly and in an orderly manner" (1 Cor 14:40).

G. The events of the end time are not necessarily chaotic or ambiguous. The worship of the last-day church should reflect an orderly progression toward a predetermined goal. The Holy Spirit has nothing in common with disorder and confusion (Holmes, Sing a New Song, 91).

\section{Some Guiding Principles in Planning Worship}

The pastor, as worship leader, has to recognize that in planning worship he needs to work very closely with the worship committee or the church board. $\mathrm{He}$ needs to remember that daring to try new things always carries a risk. Preparing a worship service should include all that will enrich and aid worship and exclude all that will impoverish or hinder true worship. Here we have some suggestions given by Franklin M. Segler:

A. Specific persons must accept the responsibility for planning worship. This responsibility should be taken seriously and carried forward with discipline. Ordinarily, the pastor or senior minister is primarily responsible for planning the order of worship. He should plan the design for each service of worship, keeping in mind the theme which will emphasize in all the elements. He should give attention to every detail of the order, especially the call to worship, the prayers, the hymns, and the Scripture selections.

B. Plenty of time should be devoted to planning an effective order of worship.

C. The order of worship should be suited for a given congregation. Those who plan worship should beware, however, of neglecting the needs of the congregation as a whole, which will call for a well-rounded order of worship.

D. The minister should have a definite purpose in mind as he plans the order of worship. He should seek to bring the congregation to a new point of view or decision.

E. Although no one season is more important than another, many churches find it helpful to plan their worship according to the calendar of the Christian year. The observance of certain days and seasons may keep the church reminded that God who has acted in history is continuously acting in the lives of His people. 
F. A certain amount of variety in the order of worship will keep the attention of people and stimulate their concern in worship. In general, it is wise to conserve the overall design of the service with which a congregation is familiar. Ordinarily, the variety should come in the alteration of parts of the service within the general structure without radically changing the main structure.

To surprise a congregation with a radically new and unexpected order of worship evokes wonder at what is happening. This prevents them from focusing their attention upon God.

G. The use of manuals and other aids can assist leaders in planning worship. For example, handbooks of prayer, hymnals, and manuals on order of worship prepared by many denominations may stimulate the thinking and provide enrichment materials for those who plan worship.

H. A printed or mimeographed order of worship can aid a congregation in worship. This visual aid is particularly helpful in directing the attention to the particular objectives of the various elements in worship. This should be made as attractive as possible.

I. Planning for worship includes the preparation of the building and facilities. The house of worship should be made attractive. Cleanliness is a mark of Christian concern for God's house.

J. Creativity in planning is essential for vital worship. Neither slavish dependence upon resource materials which others have provided, nor the naive presumptuousness that no previous thought or planning is necessary for a public worship service is valid.

Vital worship costs in concern and imagination and work; for the worship of God is dialogue, and dialogue calls for involvement in the gospel of redemption.

The Holy Spirit desires to work creatively in the minds of those involved in planning worship, and $\mathrm{He}$ will inspire and guide as vitally in the planning as $\mathrm{He}$ will in the actual experience of worship (Franklin M. Segler, Christian Worship, 186-89).

Dr. C. Raymond Holmes says that as we plan our worship we have certain obligations:

A. To the ecumenical character and obligations of the times; 
B. To the nature and content of the everlasting gospel;

C. To that which the Spirit would teach us as we are on our way to the marriage feast of the Lamb when His church as bride meets the Bridegroom.

The service must have a structure and form that will make worshippers conscious of the three-time dimensions of man's existence: past, present, and future.

For Seventh-day Adventist worship, this means that the following elements of form are essential:

A. Attention must be drawn to the seventh-day Sabbath on which the congregation gathers for its worship celebration. The Sabbath may be publicized by the preached Word, but it also may be publicized in the other words that are spoken or sung in the order of service itself. The Sabbath reminds us of the past dimension of human existence, of our origin as sons and daughters of God.

B. Attention must be drawn to the heavenly sanctuary and the ministry of Christ there, into which the worshipping congregation has entered by faith. It makes us conscious of the present dimension of life, enabling us to see life in proper relationship to contemporary events in heaven.

C. Attention must be drawn to the second advent of Christ, which is the hope that the congregation takes with it into the world for the following six days. This too should be publicized in the order of service. It provides the future dimension of human existence.

D. The Word of God must be preached. No Adventist worship service should take place without the public proclamation of the eternal gospel, both law and grace. The Seventh-day Adventist Church has a mission of proclamation for which it dares not apologize. It is a message-oriented church, a preaching church; and therefore, the communication of the message God has revealed for the end times must be a central feature.

E. The Eucharist, or holy communion, must be celebrated on a regular basis. In accordance with the Scriptures the gathered congregation must celebrate the sacramental Word in communion by the eating of bread and the drinking of the unfermented juice of the grape. An essential part of the service, however, is the washing of feet. 
F. Baptism is also a major event in Adventist worship. As the symbolic act signifying burial and resurrection with Christ to a new life of faith and obedience, it can never be thought of as incidental service. It should always take place in the presence of a congregation, or at least a portion of a congregation, as it is not a private affair. It signifies entrance into, and acceptance by, the family of God.

G. Every worship service meets in the name of Jesus Christ, the Creator and Redeemer of the world. "Where two or three come together in my name, there am I with them" (Matt 18:20, NIV).

\section{A Proposed Order of Worship}

"Our meetings for worship should be sacred, precious occasions. ...

Brethren, unless you educate yourselves to respect the place of devotion, you will receive no blessing from God. You may worship Him in form, but there will be no spiritual service" (White, $\underline{5 T}, 607,608$ ).

No one thing in a service of worship in unimportant. The announcements, the offering, the organ voluntary, all can and should be acts of worship. And it is the leader's responsibility to so organize his worship program that these items will form a true progression toward the rededication of the life of each member of the congregation to God and His service.

A. The bulletin. The order of service is definitely helped if the congregation understands the order in which the service will proceed. The publishing of a bulletin including the announcements and the order of service will do much to aid worship.

B. Place of announcements. If made before the actual service begins, the effect is much better. It is psychologically unsound to open the service of worship with a doxology and after the invocation and then proceed to break the worship progression while someone gives out the week's appointments. The leader of worship should be the last one to permit the intrusion of things strange and irrelevant.

C. Call to worship. May be sung by a choir. After the choir (if there is one) sings a prelude, those who lead the worship enter and all is hushed to silence while they kneel in silent prayer, consecrating themselves and dedicating the service of the hour to God. A choral amen is the signal for the ministers to rise and stand, while one steps forward and reads a suitable Scripture, such as: Pss 95-6-8; 99:1, 9; $97: 1 ; 100: 4,5$. 
Our God calls us, and this where worship begins. Most properly, therefore, the call to worship is a Word for God, a Scripture text that reflects $\mathrm{His}$ desire that we corporately come into His presence. $\mathrm{He}$ sets the tone. The dignity and weight of the worship experience depends on God's presence.

In our generation, which has made so many things common, God's holiness and essential transcendence may be forgotten. Parishioners may consider worship to a be right, coming to services with little forethought or preparation. In such cases, worship services become little more than religious exercises, spiritual pep rallies centered on reviving languishing commitments to the church program.

Yet how serious is to call people into the very presence of God! With a meaningful, weighty call to worship, we can help our people awaken to the holy moment when worship begins, when God graciously chooses to meet with His people for communion, dialogue, and renewed covenant.

D. The invocation. The invocation offered while the congregation is standing, should be short, simple, and every word well chosen. This will inspire the congregation to reach out for a deepening sense of the presence of God in their midst.

The invocation claims the promise of Jesus that "where two or three come together in my name, there am I with them" (Matt 18:20).

The invocation is the recognition that Christians worship the Father through Jesus Christ by the power of the Holy Spirit. They do not enact worship in their own power. This part requires thoughtful and careful attention, for it is a passage into the very presence of God.

E. The opening hymn. Once the congregation stands before God, it is fitting that it should recognize God for who He is. The hymn chosen should be a hymn of praise. The Scripture that has given shape to the historic burst of praise for God's character in the service of the Word is Luke 2:14, "Glory to God in the highest, and on earth peace to men on whom his favor rests."

Every hymn must be carefully selected for its particular place in the service. Although the chancel choir, the soloist, and the instrumentalists are all vital contributors to the music of worship, our most important choir is made up of the men and women with untrained voice who sit in the pews. 
The selection of hymns has a powerful influence on the overall mood and worship experience. Congregational singing, even though it is done with hundreds of other people, can be a powerfully personal expression of worship. It can implant truths in the lives of individuals.

The point of the funnel is to draw in and unify the hearts of the congregation, to focus the emotional flow of the worship experience, to prepare us for the ministry of the Word, and to allow people to express their response to God.

F. The written Word. The Holy Scripture is the record of God's redemptive acts in human history. Christians read Scripture in worship partly because of the examples of Jesus and the early church. But primarily, they read out of their conviction that they must stay in touch with God's authoritative written Word, the life source of every believer. Scripture reading in worship is both a voicing of God's Word and a listening to God's Word.

In contrast to the first Scripture reading as a call to worship which focuses upon divine initiative and His glory and majesty as Creator God who is most worthy of worship, the second Scripture reading here calls the attention to the Creator as also the Lord of history and Redeemer of mankind.

The Word not only is the symbol of the presence and reality of the invisible and intangible Creator, it is the medium of His creative and transforming power, the content of His revelation, in and through Christ the eternal Word (John 1:1-3), the Truth (John 16:6), and the express image of the divine God (Heb 1:3), all of which are made manifest through the ministry of the Holy Spirit (John 16:13; cf. John 6:63).

The Word thus becomes man's basis of knowledge, faith, life, and worship.

G. The pastoral prayer. Theologically and historically, worship is prayer. Christian worship always has been essentially an act of commemoration in which we consider God's benefits to us and make an oblation of ourselves to the God of our faith.

If the minister takes seriously the fact that the congregation is praying with him, he will be careful about the way he prays. He will also be careful about the length of his prayers. Perhaps the greatest test of leadership ability comes when he leads in prayer. He must remember 
that he is not just praying on behalf of the congregation, nor just praying for them. He is leading their prayer, providing them the means by which they can unite with him in offering up to God their corporate petitions.

If a minister wishes to be effective in leading the prayers of his congregation, he must prepare for his public prayers. Pastors should be careful to see that their prayers are fresh and relevant to the spiritual needs of their congregations. The leader must lift the congregation heavenward. "Prayer does not bring God down to us, but brings us up to Him" (White, $\underline{\mathrm{SC}}, 93$ ).

H. The prayer response. Here, all the congregation sings the hymn "Hear our Prayer, Oh God" as a response in prayer of confession, thanksgiving and intercession. Choral meditation should with all other features lead to the individual's heart surrender and soul's expression in some tangible way, such offering.

We can read Ps 103:8-12 as God's assurance of His pardoning grace as the congregation rises from the prayer response.

I. The offering. Christian worship is intelligent and rational in that a total commitment of life to God comes from an encounter and response to His revelation. Man has not truly worshipped the Lord until he has fully surrendered, committed, and offered himself unto God in worship.

In offering money as an expression of worship, we are responding to God's claim on our lives and giving Him a portion of what $\mathrm{He}$ has in fact given us. This is a proper act of worship, one that should be done with dignity and thankfulness of heart.

The offering is the congregation's silent expression of devotion to God, and the total confidence in His promises.

J. Congregational singing. Music and the people of God have been partners ever since God called out a people for His name. The Scripture points out that it is God who truly gives a song. At creation the stars sang together, and when the Jewish nation was born, music was placed in the hearts of God's people. The Book of Psalms, the hymnal of Israel, is located in the center of God's Word.

A full worship service on a Sabbath morning without music, without singing, is dull and dead. Music dramatizes the transcendence of God 
and draws the worshipper into the heavenly sanctuary. It serves to pull forth from deep within the worshipper that sense of awe and mystery most appropriate to Christian worship.

Music in worship provides a degree of intensity that words alone cannot evoke. It helps the spoken word achieve an even greater power of expression. Music helps the believer to express the inexpressible. It does not exist for itself alone. It is not autonomous. It must always be subordinated to the Word and glory of God. It is not for entertaining the people, but to help them glorify God, and is for the fostering of spirituality, not simply aesthetics.

Although the chancel choir, the soloist, and the instrumentalists are all vital contributors to the music of worship, our most important choir is made up of the men and women with untrained voices who sit in the pews. All church music is secondary to congregational singing.

Hymn singing not only serves as the corporate affirmation of faith, it also serves to teach the doctrines of the church. While hymn singing can meet human needs on the deepest level of human experience, at the same time it can affirm the objective truth upon which faith and religious experience rest. Thus the kind of hymns we choose for our worship service must take into account doctrinal content as well as singability and music excellence.

Christians can view music as a great ally in ministry. Music is a tool in our hands to do the work of ministry. Music allows the people of God to join in one voice to His glory.

$\mathrm{K}$. The sermon. The Word of God is the very essence of Christian worship. It is God at work in revelation. The Word is the symbol of divine reality, the condescension of divine transcendence, the testimony of divine righteousness and holiness, the medium of His creative and transforming power.

Rev 14:6, 7 re-affirms preaching as a divine method of communication between God and persons and also describes the place where His message is to preached.

The Seventh-day Adventist Church is still committed to the centrality of preaching in the worship of God's people (2 Tim 4:2-5). Preaching is never an isolated event. It takes place in the context of life as well as in the context of worship service. It is part of the celebration of the Word of God and the celebration of the human life. 
In worship we come face to face with the reality of Christ when the Word is preached and the gospel is proclaimed. It is neither a true gospel nor a true Word if what is proclaimed does not center in Christ and uphold Him. True worship does not take place when Christ is not proclaimed and glorified. The ministry of the preached Word is thus clearly defined.

L. The closing hymn. The dedication of life to God is expressed in part through an offering, a prayer, and also a hymn of commitment. The choice of this hymn should be made for its appropriateness as far as possible because this is the high point of the whole service. This should be the congregation's response to everything before. The subject of the message determines the choice. Having felt the presence of God and communed with Him, people now are eager to express their dedication.

M. The benediction. A benediction should be a benediction--a blessing. If you have prayed as you should have prayed in the pastoral prayer, if you have preached as you should have preached, you certainly will not need a long prayer at the conclusion, but a benediction. You are speaking for God, and that blessing ought to be short. A true benediction is always inspiring, never long, always fervent, right to the point. People should go home with hearts full of gratitude for the message they have received from the Lord. The benediction is a blessing from the worship leader in the name of God.

Biblical benedictions are found in Num 6:24-26; Rom 15:3; 2 Cor 13:14; and Heb 13:20, 21.

N. The postlude. From the first note of the piano to the last peal of the organ, all must be worship.

The organ or piano postlude is a signal of dismissal of the congregation, but this is still a part of worship. The departure from the house of God to the world is as much an act of worship as the approach to His holy presence. It is just as much an act of divine initiative in drawing man to Him as being sent by Him out to the world to so live to glorify His name.

"Blessed is the preacher who converts his church into a temple, and who, with or without picture windows and without or with help of ... rich architecture, creates by the conduct of his service an atmosphere in which souls look Godward: (C. E. Jefferson, The Building of the Church, 123). 
The Role of the Minister in Worship

\section{Introduction}

The actual experience of worship depends upon three things: the worshipper himself, the Holy Spirit's power, and the human leadership provided in the order and conduct of worship.

The leader in worship is both prophet and priest. The prophet contends for change and vitality; the priest seeks stability and instruction. The prophet speaks forth the ideal and eternal truth of God; the priest comes to God in behalf of man's temporal and partial grasp of truth and reality.

These elements are always in tension in the work of the minister, and both affect his approach to leading in worship. As the pastor leads in worship, he is not acting for himself alone, but for and with the congregation. The minister is not only the transmitter of the things of the people through Christ to God and the things of God through Christ to the people; he is also one of the company of transmitters. He is a member of a line. He acts not merely as an individual but as one of a team.

A pastor, of course, must do many things to prepare to lead people weekly in worship, from preparing a sermon to putting hymnals in place. But before I attend to technical matters, I have learned to attend to spiritual concerns.

\section{The Leader's Spirit}

A. The leader must commit himself anew for each particular occasion. His private prayer period is supremely important. Charles Spurgeon once said that the man who guides others into the presence of the King must have journeyed far into the King's country and often looked upon his face.

B. The leader of worship should subordinate himself and exalt God as the objective of worship.

C. The spirit of the leader should be characterized by seriousness, reverence, joy, disciplined enthusiasm, hope, expectancy, and humility. All these are dependent upon the grace of God through the Holy Spirit. 
D. The minister should have a relationship with Christ as Christ has with the Father. His relationship with the Father is revealed in passages such as these:

"Believe me when I say that I am in the father and the father is in me; ..." (John 14:11a).

"All that belongs to the father is mine. ..." (John 16:15a).

"I and the father are one" (John 10:30).

". . Understand that the father is in me, and I in the father" (John $10: 38 b)$.

". . Anyone who has seen me has seen the father" (John 14:9b).

$"$.. He who receives me receives the one who sent me" (Matt 10:40; cf. Mark 9:37).

E. Language like that used to describe the relationship of Christ to the Father is also used by Christ to describe our relationship to Him.

"My prayer is ... that all of them may be one, father, just as you are in me and I am in you. May they also be in us so that the world may believe that you have sent me. . . That they may be one as we are one: I in them and you in me" (John 17:20-23).

"I tell you the truth, whoever accepts anyone I send accepts me; and whoever accepts me accepts the one who sent me" (John 13:20).

F. The relationship of the minister to Christ is such that what one does with one, he may be doing with the other. No one originates his own life or sustains it by his own power. Our fulfillment is never in ourselves. Each of us a part of a web of reality, an intricate complex of coherence.

G. The pattern behind human relations is ultimately that found within the blessed Trinity. Our patterns of relationship are found in God, not in a broken human society.

H. The minister stands in God's stead. He acts out the immanence of God by his daily involvement in the suffering of his people. Shared suffering is at the heart of pastoral ministry, as the pastor takes the burdens of his people into his own life and thus helps to alleviate 
them. How important is the intimate relationship of the minister with God to be a real leader in worship.

\section{Personality of Worship Leader}

A. He should always strive to have the best physical condition possible.

B. He should be careful about externals.

"Our words, our actions, our deportment, our dress, everything should preach. Not only with our words should we seek speak to the people, but everything pertaining to our person should be a sermon to them: (White, Ev, 671; see also pp. 670-674; cf. also GW, 172; $\underline{6 \mathrm{~T}}, 96$ ).

C. He needs to be careful with his gestures, posture and decorum (cf. White, GW, 172; $\underline{1 \mathrm{~T}}, 648-649 ; \underline{2 \mathrm{~T}}, 612-613)$.

D. Personality may be defined as that sum-total attracting or repelling force which an individual radiates to his fellows, because of certain qualities of being, habits, and attitudes.

E. The worship leader must seek to be calm, composed, dignified, and gracious.

"Personality is the extent to which the individual has developed habits and skills which interest and serve other people" (Dr. Henry C. Link).

"Personality is the expansive self, the inner-you showing a desire to share heart-friendliness" (Elizabeth von Hesse).

"Never be afraid of raising the standard too high. All coarseness and roughness must be put away from us. Courtesy, refinement, Christian politeness, must be cherished. Guard against being abrupt and blunt. Do not regard such peculiarities as virtues, for God does not so regard them" (White, Review and Herald, Nov. 25, 1980.

F. Principles for personality development

1. Speech. The talent of speech and delivery is to be developed. Eccl 12:9-11, "The human voice is a precious gift of God, it is a power for good, and the Lord wants His servants to preserve its pathos and melody. The voice should be cultivated so as to promote its musical quality, that it may fall pleasantly upon the ear and impress the heart" (White, Ev, 667, 668). 
2. God commissions His ministers to preach with power (Isa 40:9).

3. Christ's "word was with power" (Luke 4:32). He spoke graciously. "The love expressed in look and tone, drew to Him [Jesus] all who were not hardened in unbelief. Had it not been for the sweet sympathetic spirit that shone out in every look and word, He would not have attracted the large congregations that He did" (White, DA, 254).

"His voice was as music to those who had listened to the monotonous tones of the rabbis" (Ibid., 253).

4. Speak with enlarged conversational tones. Avoid "preacher's whine" (White, Ev, 671).

G. Dress

1. Garments of ancient priests symbolic of their service (Exod 28:2; see White, PP, 350-351).

"Our words, our actions, our deportment, our dress, everything, should preach. Not only with our words should we speak to the people, but everything pertaining to our person should be a sermon to them" (White, Ev, 671).

H. Gestures and decorum

1. Leader of worship must not attract to himself. He is a guide leading men to God.

2. Avoid crude and grotesque attitudes.

"Jesus, the greatest Teacher the world ever knew, was calm, earnest, and impressive in His discourses. He is our example in all things" (White, Ev, 184).

"Much of the effect of discourses is lost because of the manner in which they are delivered" (Ibid., 183).

"Preach the Word, as Christ, the Son of God, preached the Word. Violent gesticulations detract greatly from the impressions the truth would make upon human hearts, and lessen the force of the demonstrations of the Spirit of God" (Ibid., 184). 
If the proclamation of God's Word doesn't come out of an intimate walk with Him, it will be empty instead of the living Word.

\section{The Minister: Prophet and Servant}

A. In worship the minister represents the offices of prophet and servant.

1. "Prophet" is derived from the Greek prophetes, meaning, to speak on behalf of someone else.

2. The minister-prophet is as the Lord said of Ezekiel, "Son of man, I have made you a watchman for the house of Israel" (3:17).

B. The minister today, as the prophet of God, must be sensitive to God's word and be able to relate the divine message to the everchanging needs of mankind.

1. He must have a message, and he must be able to present the same to his people.

2. He is the interpreter of the truth, the embassador of Christ, the voice crying in the wilderness.

3. As a watchman, he is called upon to warn the sinner of God's judgment (Ezek 33:7; Heb 13:17).

C. The minister as servant speaks to God on behalf of the people.

1. There are times when he, like Moses of old, stands in the rift and pleads for his people to the point of casting his own life on the balance (Exod 32:32; Rom 9:3).

2. The ministry of sympathy. People do not come to church to be scolded; they come to be helped. It is the privilege of the minister to encourage the downhearted, comfort the bereaved, sympathize with the afflicted, and inspire the fainthearted.

3. To perform his ministry effectively in these areas of human need, the must have an intimate acquaintance and relationship with his people. He must constantly imitate Him of whom the writer to the Hebrews said: "We have not an high priest who cannot be touched with the feelings of our infirmities; but was in all points tempted like as we" (Heb 4:15). 
D. The offices of prophet and servant are not performed in a vacuum. They become meaningless apart from the people. Likewise the office of the minister is only significant in relation to the people whom he serves.

1. The minister's usefulness and effectiveness will depend to a large degree upon his willingness to "sit where the people sit."

2. The ministry is not a "one-way" but a "two-way" street.

\section{Leading Worship}

A. Public worship consists not only of content or form, but also of actions or ceremonial. Actually, worship is an act, the presentation of ourselves and our substance to God in praise, thanksgiving, and dedication.

B. It should be remembered that worship is offered to God, hence demands dignity, reverence, and our very best in preparation, leadership, and participation.

C. We can't produce worship by seeking to bring God down to our level. Rather, we must seek to come up to His level of dialogue, which demands the attitudes of humble dependence, awe and adoration, confession and affirmation.

D. Leaders of worship will keep in mind that the corporate life of worship is central in all that is done and said. Principles for leading in worship (see Franklin M. Segler, Christian Worship, 199-202).

1. There should be complete preparation of the details of the worship service.

2. Proper mental preparation will lead to poise and a calm selfconfidence.

3. The leader should seek personal rapport with the congregation.

4. A positive attitude is essential in leading others in worship.

5. The leader should speak in a natural tone of voice, never using the perfunctory tones of the "professional clergyman." 
6. Let the minister be punctual, never beginning a service late, or allowing any part of the service to drag or to consume more than its appropriate amount of time.

7. Personal eccentricities and distracting idiosyncrasies of a leader are annoying and become a hindrance to worship.

8. The leader should reflect a spirit of optimism and hope and enthusiasm, and never a spirit of pessimism or a sense of indifference or failure.

9. The leader of worship will participate in worship with the congregation.

10. The leader of worship should give of himself at all times.

E. Let us remember that the Holy Spirit moves in the hearts of God's people according to the preparation He finds in the place of worship.

\section{How to Plan Meaningful Worship Services}

\section{Introduction}

"Our meetings should be made intensely interesting. They should be pervaded with the very atmosphere of heaven. Let there be no long, dry speeches and formal prayers merely for the sake of occupying the time. All should be ready to act their part with promptness, and when their duty is done, the meeting should be closed. Thus the interest will be kept up to the last. This is offering to God acceptable worship. His service should be made interesting and attractive and not be allowed to degenerate into a dry form. We must live for Christ minute by minute, hour by hour, and day by day; then Christ will dwell in us, and when we meet together, His love will be in our hearts, welling up like a spring in the desert, refreshing all, and making those who are ready to perish, eager to drink of the waters of life" (White, 5T, 609 [emphasis supplied]).

"The evil of formal worship cannot be too strongly depicted, but no words can properly set forth the deep blessedness of genuine worship. When human beings sing with the spirit and understanding, heavenly musicians take up the strain and join in the song of thanksgiving" (White, 9T, 143).

I. Change is not Always Welcome 
A. We all love progress, but we are reluctant when change is imposed upon us? People often experience uneasiness, even fear about change in their pattern of worship.

"You would think that of all places, all communities, it would be in the church where we would most welcome the creativity and freshness and adventure of new things, ... . But instead that's the very place we are most threatened" (Eugene Peterson, Run with the Horses, 51).

B. Habit and heritage are two big reasons why people resist change.

1. Most of us are as defensive in our Christianity as in any other area of our lives.

2. When someone suggests changes in the worship service, the common response is akin to the apocryphal seven last words of the church: "We've never done it that way before."

3. People especially treasure the music of their formative years. It is these experiences of the sacred that indelibly stamp themselves on people's minds and create worship memories that we tamper with at our peril.

People often voice their strongest feelings over worship music; it touches their roots, their emotions.

4. As worship leaders, we have to recognize that creativity poses a threat. Daring to try new things always carries a risk.

\section{Creativity in Worship}

A. Protestants have traditionally been better workers than worshippers.

1. Pastors may spend fifteen hours on sermon preparation and fifteen minutes throwing the service together. Yet God wants worshippers above anything else.

2. The whole Book of Leviticus was written to teach a nation how to worship, and acknowledgment that at the center of life is the worship of God.

B. Christian worship requires balance. 
1. A congregation that praises loudly without worshipping meekly has not experienced the awesome and terrible side of the Almighty. To celebrate His presence is one thing; to tremble before Him, as the Psalmist exhorts, is another.

2. The skillful leader woos the congregation into worship like the patient lover draws the beloved. The congregation is brought into the audience of God more by evoking than provoking.

3. Creativity in worship is indispensable, in spite of the dangers. Worship is a verb and it requires active participation. In responding to God we should be open to using every expression of beauty and genius, which are reflections of His own nature.

4. Worship is a relational response. In some ways it is like a marriage. The more routine and predictable we allow our marriage to become, the more we begin to take our relationship for granted. But if every day we share together some new expression, gift, act of love, or experience, our relationship will keep growing. Similarly, when worship becomes predictable, it can become ordinary and lose its impact.

C. By using creativity in challenging yet non-threatening ways, worship can enliven people's relationship with God. Creative worship helps them sustain their hunger to know God more deeply.

D. How do we move away from stiff, inflexible, and colorless worship? How do we add such creativity to worship without turning people off? (Howard Stevenson, Mastering Worship, 105-111).

1. Stay within the boundaries of trust. Worship leaders need the trust of the people to whom they are ministering. Our congregation has come to know our style of worship. We work with components people are used to and in ways that will not shock them.

a. Creativity should enhance, rather than disrupt, that community.

b. One boundary is the congregation's sense of dignity. All congregations have a point beyond which is unwise to go.

c. Determining that point comes from intuition and careful experimentation. 
d. Another boundary is the quantity. People can take only so much newness. We must operate in their comfort zone.

2. Mix the old with the new. Whenever we introduce something new, it is good to come back to something familiar.

a. We should balance great choral masterworks with choral offerings that most of our people appreciate more naturally.

b. A highly contemporary musical will need to be counterbalanced with a familiar solo or hymn.

3. Do not manipulate. Creativity can effectively engage people with the genuine emotion of the gospel. But we should not use emotion to manipulate.

a. The object is not to create euphoria or bring tears.

b. Nor should creativity be employed for shock value.

c. Rather it should fill worship with an air of spontaneity, freshness, and adventure in responding to God.

d. Emotion is not an end in itself. It is a by-product of genuine worship.

e. Creative worship is not always focused on emotion. Worship uses the whole range of human responses, from the highly rational to the highly emotional, and many things in between.

4. Remain sensitive to people's response. We, worship leaders, need to be sensitive to how creativity is applied. We want people to remain open to innovation in worship.

a. We must be especially sensitive to how people accept even the smallest changes.

b. Before and after every innovation, ask these questions:

(1) Does this heighten "spectatorism," or will it involve people in worship in new and meaningful ways? 
(2) Is there a danger of fostering a "can-you-top-this" syndrome with this worship experiment?

(3) Does this take people too far out of their comfort zone?

(4) Is this innovation an acceptable risk? If it bombs, can we recover gracefully?

5. Get affirmation of colleagues. In developing and implementing creative worship, it helps to have the affirmation of colleagues.

a. Even solo pastors know key people both inside and outside the church they can consult with new worship ideas.

b. Remind yourself to be patient with creative worship innovations. Good ideas don't need to be implemented immediately; they will still be good ideas in six months or a year.

c. We need to lay the proper groundwork, think them through carefully, and get all the advice you can.

d. Chances of improving worship through creativity will rise dramatically with careful preparation on all fronts.

6. The Bible is clear: The gospel never changes, but culture does-rapidly. So our worship forms and styles must be flexible and open to innovation if we desire to stay effective.

a. Creativity is taking a fresh look at the familiar.

b. The higher the predictability, the lower the impact.

III. Meaningful Worship Services

A. To have meaningful worship services in the Adventist Church, we need to keep sight of the biblical message.

B. To have meaningful worship services, the worship leader must have always present the influence of the writings of Ellen G. White. 
C. Let us be faithful Sabbath keepers, obedient in Christian living, and participate in world and local evangelism in which every member may personally share.

D. Some ideas for meaningful worship services:

1. Give the congregation a simple but meaningful part to recite in a reading; for example, Ps 136.

2. Asking children to come forward to sing, read, or pray brings adults to attention.

3. Sometimes arrange groups of young people to stand in the congregation and read a declaration of God's goodness, majesty, or mercy.

4. The use of fresh vocabulary can also inject some creativity into worship. Books of poetry and creative prose can help to do that.

5. Use responsive reading a group who practices and presents a reading.

6. Use hymns as prayers; use the Psalms.

7. Adapt your sermon in different ways; use music, some drama, poetry, a dialogue sermon on the person and character of Jesus.

8. Sometimes give the congregation more time to sing.

9. Personal testimony is a powerful tool in worship, use it from time to time.

E. The possibilities are nearly endless. We need to put our creativity at work.

F. "The prophet Jeremiah used allegory, analogy, dramatic role-play. The prophets howled; they wailed; they wept, they acted; they sang. They reveled in the use of imagery, unafraid to use their visual imaginations. They spoke and acted symbolically. And in our times, in our imagedominated culture, so must we. Symbols in worship are powerful. they can jump the defenses of the intellect" (Karen Burton Mains, "Symbolism in Worship," in Leadership Handbooks of Practical Theology, 2 vols., ed. James D. Berkley, 1992, 1:249, 250). 
Conclusion

Worship means coming to God on His terms and encountering Him. And that, of course, is the reason for all our attempts at balance--to enable people to enter the presence of God to worship. 


\section{BIBLIOGRAPHY}

Aalders, G. C., "Genesis." Bible Student's Commentary. Grand Rapids, MI: Zondervan Publishing House, 1981. 1:135, 136.

Abba, Raymond. Principles of Christian Worship. New York: Oxford University Press, 1957.

Allmen, J. J. von. Worship: Its Theology and Practice. New York: Oxford University Press, 1965.

Anderson, A. A. The Book of Psalms, NCBC. 7 vols. Grand Rapids, MI:

Wm. B. Eerdmans Pub., Co., 1972.

Anderson, Bernard W. Understanding the Old Testament. 2d ed. Englewood Cliffs, NJ: Prentice Hall, 1966.

Anderson, Robert Mapes. Vision of the Disinherited: The Making of American Pentecostalism. New York: Oxford University Press, 1979.

Andreasen, Neils-Erik. Rest and Redemption. Berrien Springs, MI: Andrews University Press, 1978.

Andrews, John N. History of the Sabbath and First Day of the Week. Battle Creek, MI: Steam Press, 1861.

Bacchiocchi, Samuele. Divine Rest for Human Restlessness. Rome: Pontifical Gregorian University Press, 1980.

Bamberger, Bernard J. The Story of Judaism. New York: Schocken Books, 1970.

Barth, Karl. Church Dogmatics. 4 vols. Edinburgh: T. \& T. Clark, 1958.

- The Knowledge of God and the Service of God. London: Hodder and Soughtoughton, 1938. 
Barret, David. "Charismatics on Evangelism." Christianity Today, September 16, 1991, 52.

. World Christian Encyclopedia. 2 vols. Oxford: Oxford University Press, 1982.

Bennett, Dennis J. Nine O'clock in the Morning. Plainfield, NJ: Logos International, 1970.

Berkley, James D., ed. Leadership Handbooks of Practical Theology. Vol. 1. Grand Rapids, MI: Baker Book House, 1992.

Blackwood, Andrew W. The Fine Art of Public Worship. New York: AbingdonCokesbury Press, 1939.

Brown, Raymond E. Priest and Bishop. New York: Paulist Press, 1970.

Brunner, Emil. Man in Revolt; A Christian Anthropology. Philadelphia: Westminster Press, 1947.

Brunner, Peter. Worship in the Name of Jesus. Translated by M. H. Bertram. St. Louis, MO: Concordia Publishing House, 1968.

Calvin's Commentaries. Grand Rapids, MI: Wm. B. Eerdmans Publishing Company, 1948. 1:223.

Cate, Robert L. A Story of the New Testament and Its Times. Nashville: Broadman Press, 1991.

Cody, Aelred. "Priesthood in the Old Testament." Studia Missionalia. Rome: Gregorian University Press, 1973. 22:310.

Comprehensive Index to the Writings of Ellen G. White. 3 vols. Mountain View, CA: Pacific Press Publishing Association, 1962.

Conn, Charles W. Like a Mighty Army. Cleveland: Pathway Press, 1977.

Craft, Charles H. Christianity with Power. Ann Arbor, MI: Servant Publications, 1989.

Crews, Joe. "Insights into the Celebration Church." Pilgrim's Rest. Beersheba Springs, TN: By the author, 1992. 
Cruz, Jaime. "Worship Attitudes of Seventh-day Adventist Churchgoers at Montemorelos, Mexico." D.Min. project report, Andrews University, 1978.

Cullman, Oscar. Early Christian Worship. Chicago: Henry Regnery Company, 1953.

Culpepper, Robert H. Evaluating the Charismatic Movement. Valley Forge, PA: Judson Press, 1977.

Damboriena, Prudencio S. J. Tongues as Fire. Washington, DC: Corpus Publications, 1969.

Dayton, Donald W. Theological Roots of Pentecostalism. Grand Rapids, MI: Wm. B. Eerdmans, 1987.

Delling, Gerhard. Worship in the New Testament. Philadelphia: Westminster Press, 1962.

Duin, Julia. "Catholics on the Pentecostal Trail." Christianity Today, June 22, 1992, 25.

du Pleiss, David. A Man Called Mr. Pentecost. Plainfield, NJ: Logos International, 1977.

- The Spirit Bade Me Go. Plainfield, NJ: Logos International, 1970.

. "The New Pentecost." Logos Journal, March-April, 1974, 2.

Durasoff, Steve. Bright Wind of the Spirit: Pentecostalism Today. Englewood Cliffs, NJ: Prentice Hall, 1972.

Dyrness, William. Themes in the Old Testament Theology. Downers Grove, IL: InterVarsity Press, 1979.

Ewart, Frank J. The Phenomenon of Pentecost. Hazelwood, MO: Word Aflame Press, 1947.

Finkelstein, Lewis. "The Origin of the Synagogue." Proceedings of the American Academy for Jewish Research 1 (1928-30): 49-59; 2 (1931): 69-81.

Fredericks, Richard. "To Celebrate or Not to Celebrate!" Ministry, August, $1992,7$. 
"Genesis." Seventh-day Adventist Bible Commentary. Edited by F. D. Nichol. Washington, DC: Review and Herald, 1953-57. 1:244.

"Genesis to Deuteronomy." Matthew Henry's Commentary. Old Tappan, NJ: Fleming H. Revell Company, 1:46.

Giller, Eoin. "Worship Renewal in the Seventh-day Adventist Church," Ministry, October 1991, 18.

Gowan, Donald E. Bridge Between the Testaments. Philadelphia: Fortress Press, 1967.

Grosboll, Marshall. "No Time to Celebrate." Our Firm Foundation, December 1990, 15.

Haines, Lee. "Genesis and Exodus." The Wesleyan Bible Commentary. Grand Rapids, MI: Wm. B. Eerdmans Publishing Company, 1967. 1:42.

Harper, Michael. As at the Beginning. Plainfield, NJ: Logos International, 1971.

Hasel, Gerhard F. "The 'Third Wave' Roots of Celebrationism." Adventists Affirm, Fall 1991, 36.

- Speaking in Tongues. Berrien Springs, MI: Adventist Theological Society Publications, 1991.

Hayford, Jack, John Killinger, and Howard Stevenson. Mastering Worship. Portland, OR: Multnomah Press, 1990.

Herbert, A. H. Worship in the Ancient Israel. Richmond, VA: John Knox Press, 1959.

Hislop, D. H. Our Heritage in Public Worship. Edinburgh: T. \& T. Clark, 1935.

Hocken, Peter. "The Pentecostal-Charismatic Movement as Revival and Renewal." Pneuma, 3:1 Spring 1981, 31-47.

Holmes, C. Raymond. Sing a New Song. Berrien Springs, MI: Andrews University Press, 1984.

. "Authentic Adventist Worship." Ministry, October 1991, 15. 
Hummel, Charles G. Fire in the Fireplace: Contemporary Charismatic Renewal. Downers Grove, IL: InterVarsity Press, 1978.

Hunter, Harold D. Spirit-Baptism: A Pentecostal Alternative. Lanham, MD: University Press of America, 1983.

James, E. O. The Nature and Function of Priesthood. London: Thames and Hudson, 1955.

Jefferson, Charles E. The Building of the Church. New York: Macmillan Company, 1910.

Jones, Ilion T. A Historical Approach to Evangelical Worship. New York: Abingdon Press, 1954.

Josephus Antiquities of the Jews. Translated by William Whiston. Kregel Publications.

Koh, Oliver Kan-Song. "A Proposed Order of Worship for the Seventh-day Adventist Church Informed by the Theological Presuppositions Implied in the Genesis Account of Creation and Fall of Man, and the Covenant Promise of Genesis 3:15." D. Min., project report, Andrews University, 1982.

Kubo, Sakae. God Meets Man. Nashville: Southern Publishing Association, 1978.

Leclercq, Jacques. Man of God for Others. New York: Newman Press, 1968.

"Letters to the Editor." Kalamazoo Gazette, 1977.

Leupold, H. C. Exposition of Genesis. Grand Rapids, MI: Baker Book House, 1953.

Levine, Baruch A. In the Presence of the Lord. Leiden: E. J. Brill, 1974.

Marsden, George M. "From Fundamentalism to Evangelism: A Historical Analysis." In The Evangelicals, ed. D. F. Wells and J. D.

Woodbridge. New York: Abingdon Press, 1975.

Martin, Ralph P. Worship in the Early Church. Grand Rapids, MI: Wm. B. Eerdmans Publishing Company, 1975. 
. The Worship of God. Grand Rapids, MI: Wm. B. Eerdmans Publishing Company, 1982.

McDonald, Alexander B. Christian Worship in the Primitive Church. Edinburgh: T. \& T. Clark, 1935.

Menzies, William W. "The Non-Wesleyan Origins of the Pentecostal Movement." In Aspects of Pentecostal Charismatic Origins, ed. A. Syman. Plainfield, NJ: Logos International, 1975.

Mills, Watson E. Understanding Speaking in Tongues. Grand Rapids, MI: Wm. B. Eerdmans Publishing Company, 1972.

Morris, Leon. The Gospel According to John. NICHT. 11 vols. Grand Rapids, MI: Wm. B. Eerdmans Publishing Company, 1971. 4:195.

Nelson, Douglas. "For Such a Time as This." Ph. D. dissertation, University of Birmingham, 1981.

Nichol, John Thomas. Pentecostalism. New York: Harper and Row, 1966.

O'Connor, Edward D. The Pentecostal Movement in the Catholic Church. Notre Dame, IN: Ave Maria Press, 1971.

Oesterley, W. O. E. The Jewish Background of the Christian Liturgy. Oxford: Clarendon Press, 1925.

Oesterley, W. O. E., and Theodore H. Robinson. Hebrew Religion: Its Origin and Development. New York: Mcmillan Company, 1937.

Ostling, Richard N. "Counting Every Soul on Earth." Time, May 3, 1982, 67.

Ottley, R. L. The Religion of Israel. Cambridge: The University Press, 1905.

Pease, Norval F. And Worship Him. Nashville: Southern Publishing Association, 1967.

Peck, Clayton. "Does It Matter How We Worship?" Adventist Review, May 28, $1992,8$.

Peters, John Punnet. The Religion of the Hebrews. Cambridge: Harvard University Press, 1932. 
Peterson, Eugene H. Run with the Horses. Downers Grove, IL: InterVarsity Press, 1983.

Phillips, McCandlish. "And There Appeared to Them Tongues of Fire." Saturday Evening Post, May 16, 1964, 31-40.

Poloma, Margaret. The Charismatic Movement: Is This a New Pentecost? Boston: Twayne Publishers, 1969.

Pope, Richard M. The Church and Its Culture. St. Louis, MO: 1965.

Pritchard, Linda K. "Religious Change in Nineteenth-Century America." In TheReligious Consciousness, ed. Charles Y. Glock and Robert N. Bellah. Berkeley: University of California Press, 1976.

Quebedeaux, Richard. The New Charismatic II. San Francisco, CA: Harper and Row, 1983.

Ranaghan, Kevin, and Dorothy Ranaghan. Catholic Pentecostals. New York: Paulist Press, 1969.

Rayburn, Robert G. O Come, Let Us Worship. Grand Rapids, MI: Baker Book House, 1980.

"Rector and a Rumpus." Newsweek, July 4, 1960, 77.

Richardson, Cyril. "Worship." Interpreter's Dictionary of the Bible. Edited by G. A. Buttrick et al. Nashville: Abingdon Press, 1962. 4:883-84.

Rodríguez, Angel Manuel. "Substitution in the Hebrew Cultus and in Cultic Related Texts." Th. D. dissertation, Andrews University, 1979.

Rowley, H. H. The Faith of Israel. London: SCM Press, 1956.

Samples, Kenneth R. "The Recent Truth about Seventh-day Adventism." Christianity Today, February 5, 1990, 19, 20.

Segler, Franklin M. Christian Worship. Nashville: Broadman Press, 1967.

Seltzer, Robert M. Jewish People, Jewish Thought: The Jewish Experience in History. New York: Macmillan Publishing Company, 1980. 
Serrou, Robert. "Nous payons cher la mort de Dieu." Paris Match, March 25, 1993, 10. Cited in Bruno R. Vertallier, "A Design for Spiritual

Formation During the Academic Life of the Adventist Seminary Students at Collonges-Sous-Saleve, France." D. Min. dissertation, Andrews University, 1993.

Seventh-day Adventist Bible Dictionary. Edited by Siegfried H, Horn.

Washington, DC: Review and Herald, 1982.

Shea, William H. "God: Transcendent or Immanent?" Adventist Review, November 1, 1990, 14.

Shelton, Kenny. "What's Wrong with Celebration?" West Frankfort, IL: By the author.

Shimper, F. M., to James White, Review and Herald, August 19, 1851, 15.

Sigal, Phillip. Judaism: The Evolution of Faith. Grand Rapids, MI: Wm. B. Eerdmans Publishing Association, 1988.

Sirks, G. J. "The Cinderella of Theology: The Doctrine of the Holy Spirit." Harvard Theological Review, April 1957, 50.

"Speaking in Tongues." Time, August 15, 1960, 53, 55.

Strand, Kenneth A., ed. The Sabbath in Scripture and History. Washington, DC: Review and Herald, 1982.

Sullivan, Francis A. Charism and Charismatic Renewal. Ann Arbor, MI: Servant Books, 1982.

Synan, Vinson. The Holiness-Pentecostal Movement. Grand Rapids, MI: Wm. B. Eerdmans Publishing Company, 1971.

Thompson, Ron. "The Celebration Approach to Worship." Our Firm Foundation, July 1991, 21.

Trinity. 1 vol., no. 2, 1961-62.

Vaux, Roland de. Ancient Israel: Its Life and Institutions. 2 vols. New York: McGraw-Hill Book Company, 1965.

Von Allmen, J. J. Worship: Its Theology and Practice. New York: Oxford University Press, 1965. 
von Rad, Gerhard. Old Testament Theology. 2 vols. New York: Harper and Row, 1962.

Wagner, C. Peter. "A Third Wave?" Pastoral Renewal, July-August, 1983, 1-5; quoted in John Wimber and Kevin Springer, Power Evangelism. San Francisco, CA: Harper and Row, 1986, 122.

- How to Have a Healing Ministry Without Making Your Church Sick. Ventura, CA: Regal Books, 1988.

Walker, Williston. A History of the Christian Church. New York: Charles Scribner's Sons, 1970.

Waterman, G. H. "Sabbath." The Zondervan Pictorial Encyclopedia of the Bible. Grand Rapids, MI: Zondervan Publishing House, 1975. 5:183.

Weber, Martin. Adventist Hot Potatoes. Boise, ID: Pacific Press Publishing Association, 1991.

Webber, Robert E. Worship Old and New. Grand Rapids, MI: Zondervan Publishing House, 1982.

. Worship Is a Verb. Waco, TX: Word Books, 1985.

Wells, David F., and John D. Woodbridge. The Evangelicals: What They Believe, Who They Are, Where They Are Changing. New York: Abingdon Press, 1975.

White, Arthur L. "Bible Study vs. Ecstatic Experiences." Review and Herald, March 22, 1973, 7.

. "Ellen G. White and the Baptism of the Holy Spirit." Review and Herald, April 19, 1973, 8.

. "Face to Face with the Spurious." Review and Herald, March 29, 1973, 10.

. "The Gift of Tongues at Portland, Maine." Review and Herald, April 5, 1973, 7 .

. "God-Given Criteria." Review and Herald, April 26, 1973, 8.

. "Miraculous Healing." Review and Herald, April 12, 1973, 4. 
- "Tongues in Early Seventh-day Adventist History." Review and Herald, March 5, 1973, 1.

. "The Word-Not Feeling." Review and Herald, August 17, 1972, 4.

White, Ellen G. Acts of the Apostles. Mountain View, CA: Pacific Press Publishing Association, 1911.

- Child Guidance. Mountain View, CA: Pacific Press Publishing Association, 1974.

- Christ's Object Lessons. Washington, DC: Review and Herald Publishing Association, 1941.

- Christian Service. Takoma Park, Washington, DC: Home Missionary Dept. of the General Conference of Seventh-day Adventists, 1947.

- The Desire of Ages. Nashville: Southern Publishing Association, 1898.

- Early Writings. Washington, DC: Review and Herald Publishing Association, 1945.

- Education. Mountain View, CA: Pacific Press Publishing Association, 1952.

- Evangelism. Washington, DC: Review and Herald Publishing Association, 1946.

- Gospel Workers. Washington, DC: Review and Herald Publishing Association, 1915.

. The Great Controversy. Mountain View, CA: Pacific Press

Publishing Association, 1950.

. "Lessons from the Life of Solomon." Advent Review, November 30, $1905,11$.

- Life Sketches. Mountain View, CA: Pacific Press Publishing Association, 1915.

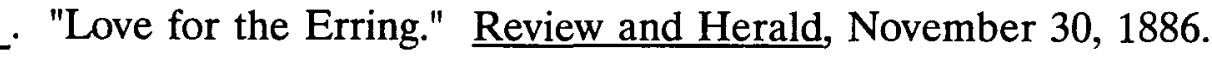


. Letter 1, 1848; reprint, Review and Herald, April 12, 1973, 5.

- Letter 28, November 7, 1850. Ellen G. White Research Center. Andrews University, Berrien Springs, Michigan. To the church in Brother Hasting's home.

- Medical Ministry. Mountain View, CA: Pacific Press Publishing Association, 1932.

. The Ministry of Healing. Mountain View, CA: Pacific Press Publishing Association, 1942.

- My Life Today. Washington, DC: Review and Herald Publishing Association, 1952.

. "The New Heart." Review and Herald, April 14, 1885.

. "Our Example.". Review and Herald, October 24, 1899.

- Patriarchs and Prophets. Mountain View, CA: Pacific Press Publishing Association, 1958.

- Prophets and Kings. Mountain View, CA: Pacific Press Publishing Association, 1973.

- Selected Messages. 2 vols. Washington, DC: Review and Herald Publishing Association, 1958.

- Signs of the Times, June 24, 1886.

- Sons and Daughters of God. Washington, DC: Review and Herald Publishing Association, 1955.

- Steps to Christ. Mountain View, CA: Pacific Press Publishing Association, 1908.

- The Story of Redemption. Washington, DC: Review and Herald, 1947.

- Testimonies for the Church. 9 vols. Boise, ID: Pacific Press Publishing Association, 1948.

- The Youth Instructor, February 15, 1900. 
White, James F. Christian Worship in Transition. Nashville: Abingdon, 1976. - Introduction to Christian Worship. Nashville: Abingdon, 1980.

White, James, to Leonard Hastings, January 10, 1850. Ellen G. White Research Center. Andrews University, Berrien Springs, MI.

White, John H. "Worship in the Pentateuch." In The Biblical Doctrine of Worship, ed. Edward A. Robson. Reformed Presbyterian Church of North America and Synods Committee on Worship, 1974.

Whitelaw, Thomas. "Genesis." The Pulpit Commentary. Grand Rapids, MI: Wm. B. Eerdmans Publishing Company, 1977. 1:92.

Widmer, Myron. "Adventist Worship-Celebration-Style." Adventist Review, November 1, 1990, 13.

Williamson, Robert L. Effective Public Prayer. Nashville: Broadman Press, 1960.

Willimon, William H. Worship As Pastoral Care. Nashville: Abingdon Press, 1979.

- Preaching and Leading Worship. Philadelphia: Westminster Press, 1984.

Wimber, John, and Kevin Springer. Power Evangelism. San Francisco, CA: Harper and Row, 1986.

Wolff, Hans Walter. "The Day of Rest in the Old Testament." Concordia Theological Monthly 43 (July-August 1972): 498-506.

World Christian Encyclopedia. 2 vols. Edited by David B. Barrett. Oxford: Oxford University Press, 1982.

"Worship and the Oneness of Christ's Church." Report of Section 14 of the Montreal Conference. Studia Liturgica 2 (December 1963): 243-255.

Woodbridge, John D., Mark A. Noll, and Nathan D. Hatch. The Gospel in America. Grand Rapids, MI: Zondervan Publishing House, 1979.

Woodward, Kenneth L., and others. "A Time to Seek." Newsweek, December 17, 1990, 56. 
Zurita, Eduardo. "Toward a Theology of Seventh-day Adventist Meeting Place, with a Study of Practical Implications and Applications Thereof." D. Min. project report, Andrews University, 1984. 
VITA

Name:

Date and Place of Birth:

Undergraduate and Graduate Schools Attended:

Degrees Awarded:

Professional Experience:
Héctor E. Ramal

October 31, 1952; Cajabamba, Cajamarca, Perú

Union College, Lima, Perú

Montemorelos University, Montemorelos, Mexico Andrews University, Berrien Springs, Michigan, USA

1977 Bachelor of Arts, Montemorelos University

1982 Master of Arts in Religion, Andrews University

1994 Doctor of Ministry, Andrews University

1977 Pastor at La Ladrillera Church in Montemorelos

1978-1980 Bible Teacher, Montemorelos University

1983-1986 Head of Religion Department and Bible Teacher at Seepapitso Secondary School, Kanye, Bostwana, Africa

1991-present Associate Professor of Theology and Pastoral Care, Montermorelos University 